\title{
Republic of Mozambique: Staff Report for the Third Review Under the Policy Support Instrument and Request for Modification of Assessment Criteria-Staff Report; Supplement; and Press Release.
}

In the context of the third review under the Policy Support Instrument and request for modification of assessment criteria with the Republic of Mozambique, the following documents have been released and are included in this package:

- $\quad$ The staff report for the Third Review Under the Policy Support Instrument and Request for Modification of Assessment Criteria, prepared by a staff team of the IMF, following discussions that ended on October 19, 2011 with the officials of the Republic of Mozambique on economic developments and policies. Based on information available at the time of these discussions, the staff report was completed on November 18, 2011. The views expressed in the staff report are those of the staff team and do not necessarily reflect the views of the Executive Board of the IMF.

- A supplement containing an Informational Annex

- $\quad$ A Press Release issued on December 7, 2011

The documents listed below have been separately released.

-Letter of Intent sent to the IMF by the authorities of the Republic of Mozambique*

-Memorandum of Economic and Financial Policies by the authorities of the

Republic of Mozambique*

-Technical Memorandum of Understanding*

*Also included in Staff Report

The policy of publication of staff reports and other documents allows for the deletion of marketsensitive information.

Copies of this report are available to the public from

International Monetary Fund • Publication Services

$70019^{\text {th }}$ Street, N.W. • Washington, D.C. 20431

Telephone: (202) 623-7430 • Telefax: (202) 623-7201

E-mail: publications@imf.org Internet: http://www.imf.org

\section{International Monetary Fund Washington, D.C.}


INTERNATIONAL MONETARY FUND

REPUBLIC OF MOZAMBIQUE

Third Review Under the Policy Support Instrument and Request for Modification of Assessment Criteria

\author{
Prepared by the African Department \\ (In consultation with other departments) \\ Approved by Roger Nord and Dominique Desruelle
}

November 18, 2011

- Program discussions: Held in Maputo, October 5-19, with Minister Chang (Finance), Cuereneia (Planning and Development), and other line ministers (Energy, Natural Resources, Women and Social Action, Transports and Communication), Bank of Mozambique (BM) Governor Gove, and other senior government officials. The mission also met with development partners and the private sector.

- Outreach: The mission conducted outreach with members of Parliament and representatives of civil society, including labor unions, think tanks and NGOs.

- Staff: Messrs. Mueller (head), Gitton, Xiao, Ms. Svirydzenka (all AFR), Ms. Garcia (SPR), Mr. Lledo (resident representative), and Ms. Bosten and Mr. Wane (resident representative office). Messrs. Conceição (OED) and Gazel (World Bank) participated in the policy discussions.

- Fund relations: The Executive Board approved Mozambique's second three-year PSI on June 14, 2010. 


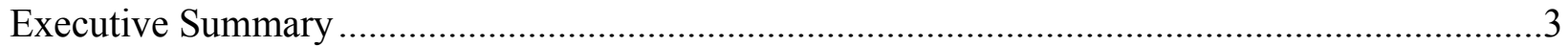

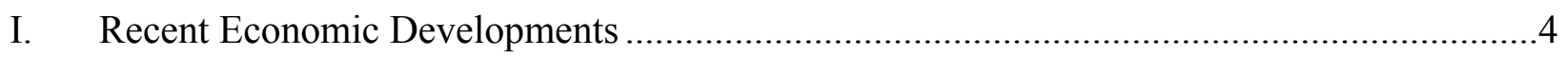

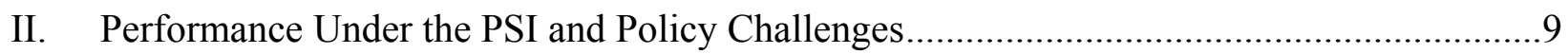

A. Performance Under the PSI ............................................................................

B. Short-Term Challenge: Curbing Inflation .............................................................10

C. Medium-Term Challenge: Creating Fiscal Space for More Inclusive Growth …......11

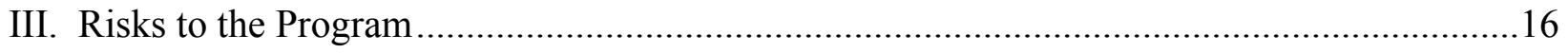

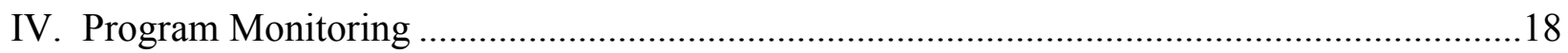

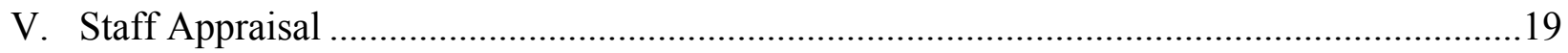

Figures

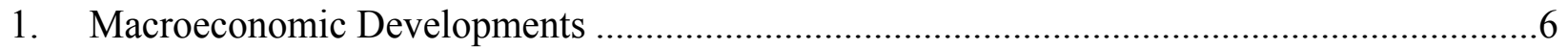

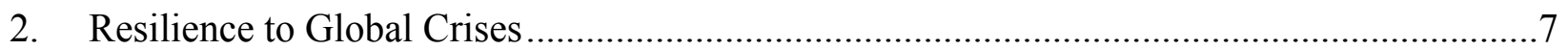

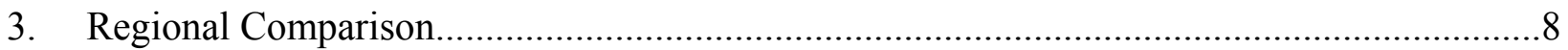

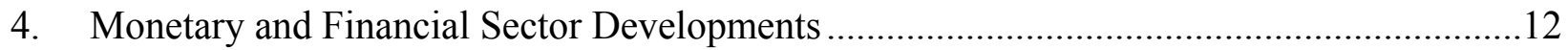

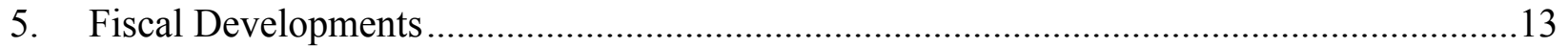

Boxes

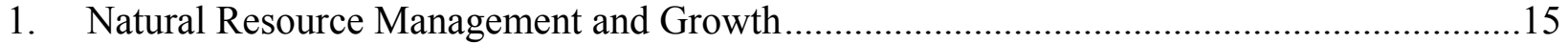

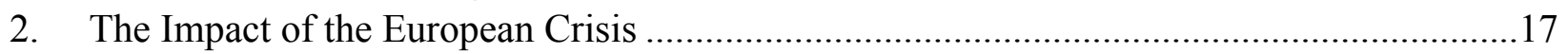

Tables

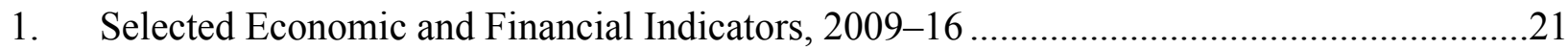

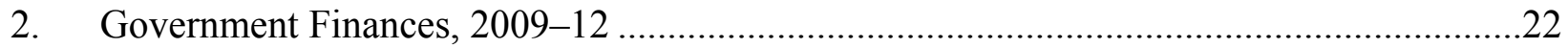

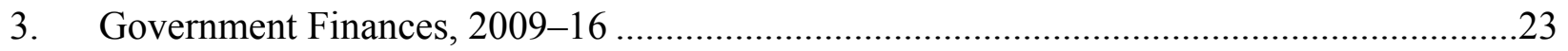

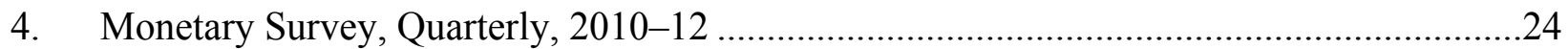

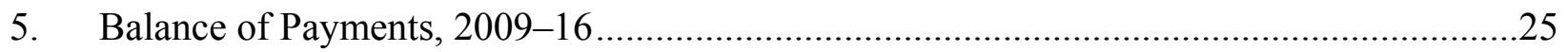

6. Financial Soundness Indicators for Banking Sector, 2001-11 ….....................................26

Appendix

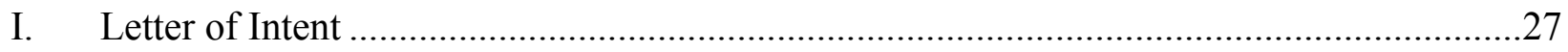

Attachment 1. Memorandum of Economic and Financial Policies ................................28

Attachment 2. Technical Memorandum of Understanding...............................................41

II. The Impact of Megaprojects on Growth in Mozambique ……................................... 47 


\section{EXECUTIVE SUMMARY}

- Mozambique continues to weather the global economic turmoil remarkably well. Real GDP growth remains buoyant, buttressed by good harvests and a robust performance in the tertiary sector. The sharp reduction in inflation reflects, among other things, the determined monetary policy tightening throughout much of the year. While risks related to the global economic turmoil have increased, Mozambique's medium-term macroeconomic outlook remains positive.

- The program is largely on track. All quantitative targets for end-June were met, except for the assessment criterion (AC) on reserve money (RM) which was missed by a small margin. The related indicative target for end-September was met comfortably. Progress on the structural front has been good. The structural benchmark on the civil service and wage database was observed, while the end-July benchmark on the submission of the anti-corruption legislation to Parliament was implemented with a three-month delay.

- The macroeconomic policy mix in the short run remains oriented toward continuing disinflation, while supporting the authorities' investment and social development objectives going forward. Monetary policy will be geared toward further reducing inflation while fostering financial deepening. Fiscal policy will seek to step up public investment to close the infrastructure gap and support an expansion of social safety nets to address chronic poverty. The necessary fiscal space is expected to be created through a continued strong revenue effort, selective nonconcessional borrowing, and a moderate increase in domestic borrowing.

- Staff recommends the completion of the third review under the PSI. It supports (i) the waiver for the minor nonobservance of the end-June 2011 AC on RM; (ii) the modification of the end-December 2011 ACs in light of economic developments to date; and (iii) the authorities' request to delay the completion of the structural benchmark on the Integrated Investment Plan from end-2011 to end-March 2012 to allow key ministry officials to benefit from World Bank training on project selection. 


\section{RECENT ECONOMIC DEVELOPMENTS}

Economic activity remains buoyant, notwithstanding the global economic turmoil. Progress in reducing inflation has been strong.

1. Mozambique's growth performance remains robust. Economic activity in the first half of 2011 is estimated at 71/2 percent, buttressed by good harvests and a strong performance in the tertiary sector. Economic growth will benefit from the coming online of two new coal mines in September, suggesting an MEFP १2 annual real GDP growth rate of 71/4 percent, in line with previous projections. Mozambique's economic growth is cementing the country's rank as one of the fastest growing economies in the region (Figures 1 to 3 ).

Mozambique : Comparison with Sub-Saharan Africa, Selected Indicators, 2004-11

\begin{tabular}{|c|c|c|c|c|c|c|c|c|c|c|c|c|}
\hline & \multicolumn{4}{|c|}{ Mozambique } & \multicolumn{4}{|c|}{ Sub-Saharan Africa (SSA) } & \multicolumn{4}{|c|}{ SSA - Frontier Economies ${ }^{1}$} \\
\hline & 2004-08 & 2009 & 2010 & 2011 & 2004-08 & 2009 & 2010 & 2011 & 2004-08 & 2009 & 2010 & 2011 \\
\hline & & & & Proj. & & & & Proj. & & & & Proj. \\
\hline Real GDP, $\%$ change & 7.8 & 6.3 & 6.8 & 7.2 & 6.5 & 2.7 & 5.4 & 5.2 & 6.7 & 4.0 & 6.2 & 6.6 \\
\hline CPI period average, $\%$ change & 10.2 & 3.3 & 12.7 & 10.8 & 8.3 & 10.6 & 7.5 & 8.4 & 10.2 & 10.5 & 9.2 & 9.1 \\
\hline REER, index & 100.8 & 101.2 & 86.0 & $\ldots$ & 101.6 & 109.7 & 108.0 & $\ldots$ & 104.4 & 110.0 & 108.7 & $\ldots$ \\
\hline Current account balance, after grants, \% GDP & -10.9 & -12.2 & -11.7 & -11.2 & 0.9 & -2.2 & -1.0 & 0.7 & -1.7 & -5.1 & -4.0 & -3.3 \\
\hline Gross international reserves, months of imports ${ }^{2}$ & 4.8 & 5.4 & 5.4 & 4.7 & 4.6 & 5.1 & 4.5 & 5.1 & 5.2 & 5.5 & 5.3 & 5.2 \\
\hline Overall fiscal balance, including grants, $\%$ of GDP & -2.7 & -5.5 & -3.9 & -3.5 & 2.1 & -5.3 & -4.2 & -2.0 & 0.1 & -5.0 & -4.4 & -4.0 \\
\hline Broad money (M3), \% of GDP ${ }^{2}$ & 30.3 & 40.2 & 42.0 & 39.5 & 42.6 & 49.5 & 48.0 & 47.9 & 30.4 & 35.4 & 36.0 & 35.6 \\
\hline Credit to the private sector, $\%$ of GDP & 14.4 & 26.8 & 29.1 & 28.8 & 16.9 & 20.6 & 21.4 & 21.8 & 17.2 & 22.3 & 22.1 & 22.4 \\
\hline
\end{tabular}

Sources: Mozambican authorities and IMF staff estimates.

${ }^{1}$ Angola, Ghana, Kenya, Mauritius, Mozambique, Nigeria, Senegal, Tanzania, Uganda and Zambia.

${ }^{2}$ For regional comparison, months of current year imports are used. Definition of reported broad money may vary across countries.

2. After peaking at end-2010, inflation has come down to single digits. The accommodating monetary policy stance adopted during the global crisis, together with balanceof-payments developments, had triggered a depreciation of the exchange rate and the emergence of strong inflation pressures in 2010. Mozambique is among the handful of sub-Saharan African (SSA) countries which has tightened monetary policy early in response to these developments. ${ }^{1}$ The authorities' policy tightening, the strong appreciation of the Metical, good harvests, and favorable developments in international food and energy prices helped bring down twelve-month inflation to $8 \frac{1}{4}$ percent by

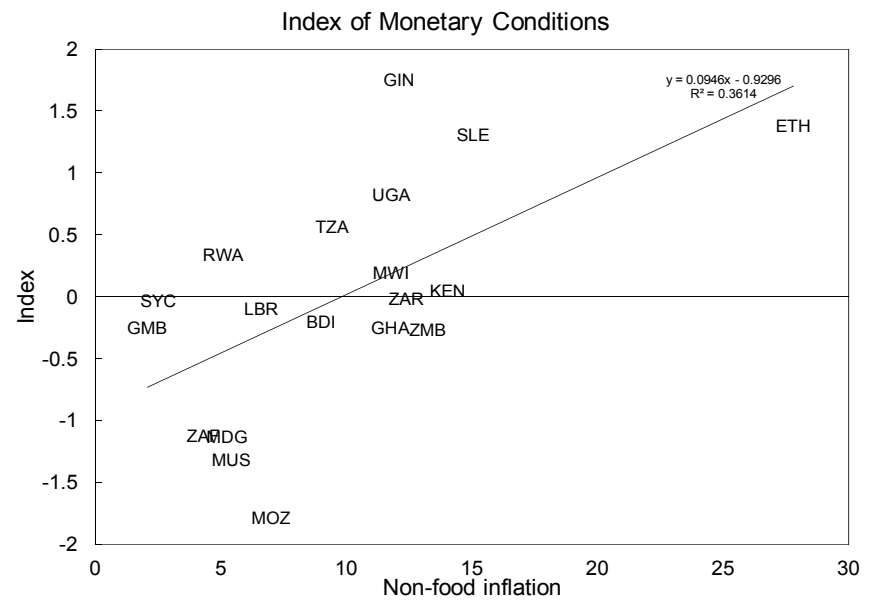

\footnotetext{
${ }^{1}$ The index of monetary conditions depicted in the text chart combines (with equal weight) changes over the last year in the nominal exchange rate vis-à-vis the U.S. dollar with the extent to which the projected monetary expansion exceeds the projected real GDP growth rate in 2011. This measure of monetary conditions is found to be generally positively correlated with inflation.
} 
October 2011, compared to its peak of 161/2 percent at end-2010. This puts the authorities in a position to reach their inflation objective of $8 \frac{1}{2}$ percent for 2011 . The food CPI was the main driver supporting the disinflation process, while the Government's upward adjustment of fuel prices in April and July did not have a significant impact on headline inflation. However, core inflation (excluding food, energy, and transport) declined at a slower pace than headline inflation, standing at $63 / 4$ percent in October compared to $11 \frac{1}{2}$ percent at its February peak.

3. Fiscal policy has supported the disinflation effort. Over the first semester of 2011, revenue performance has been strong, budget execution prudent, and the pace of execution of donor-financed capital spending slow. This, compounded by the slower-than-expected disbursements of nonconcessional borrowing (NCB) under the related program ceiling (US\$900 million), helped contain aggregate demand and supported disinflation. Overall, current indications point toward a noticeably lower fiscal deficit for 2011 as a whole than previously envisaged.

\section{Export performance and capital inflows have remained robust, while imports were}

lower than expected. The current account deficit is projected to decline slightly to about $11 \frac{1 / 4}{4}$ percent of GDP in 2011. In addition to strong exports by megaprojects in the natural resource sector benefitting from rising commodity prices, traditional exports also enjoyed a healthy rebound. This should more than offset the import bill related to fuel and food products and investment by megaprojects. These developments, together with robust aid and private capital inflows (including capital injections for several foreign-owned banks to support their business expansion), should keep the import cover of reserves at 4.5 months this year.

Mozambique: Selected Economic and Financial Indicators, 2009-16

\begin{tabular}{|c|c|c|c|c|c|c|c|c|c|}
\hline & \multirow{2}{*}{$\begin{array}{r}2009 \\
\text { Act. }\end{array}$} & \multirow{2}{*}{$\begin{array}{r}2010 \\
\text { Est. }\end{array}$} & \multicolumn{2}{|l|}{2011} & 2012 & 2013 & 2014 & 2015 & 2016 \\
\hline & & & EBS/11/80 & Proj. & \multicolumn{5}{|c|}{ Proj. } \\
\hline & \multicolumn{9}{|c|}{ (Percent of GDP, unless otherwise stated) } \\
\hline Real GDP growth (percent change) & 6.3 & 6.8 & 7.2 & 7.2 & 7.5 & 7.9 & 7.8 & 7.8 & 7.8 \\
\hline Consumer price index (annual average) & 3.3 & 12.7 & 9.5 & 10.8 & 7.2 & 5.6 & 5.6 & 5.6 & 5.6 \\
\hline Consumer price index (end of period) & 4.2 & 16.6 & 8.4 & 8.4 & 5.6 & 5.6 & 5.6 & 5.6 & 5.6 \\
\hline Credit to the economy (percentage change) & 58.6 & 27.5 & 19.5 & 17.8 & 22.1 & 20.5 & 20.8 & 21.2 & 21.9 \\
\hline Credit to the economy & 26.8 & 29.1 & 28.6 & 28.8 & 30.5 & 32.1 & 34.0 & 36.0 & 38.5 \\
\hline Current account balance, after grants & -12.2 & -11.7 & -11.4 & -11.2 & -11.1 & -11.0 & -10.8 & -10.8 & -10.5 \\
\hline Primary domestic fiscal balance & -4.3 & -3.3 & -6.4 & -3.1 & -2.0 & -2.4 & -2.2 & -2.1 & -2.1 \\
\hline Overall fiscal balance, after grants & -5.5 & -3.9 & -3.1 & -3.5 & -5.8 & -6.2 & -5.9 & -5.5 & -5.5 \\
\hline Fiscal external financing & 5.1 & 4.4 & 5.8 & 2.8 & 5.3 & 5.3 & 5.0 & 4.7 & 4.6 \\
\hline Domestic net credit to government & 0.2 & -0.6 & 0.5 & 0.8 & 0.5 & 0.8 & 0.8 & 0.8 & 0.8 \\
\hline Reserve money (percent change) & 27.3 & 29.2 & 14.3 & 13.2 & 18.3 & 18.8 & 19.5 & 20.4 & 21.8 \\
\hline Reserves (months of projected imports) & 5.2 & 4.4 & 4.5 & 4.5 & 4.6 & 4.7 & 4.8 & 4.9 & 5.0 \\
\hline
\end{tabular}

Sources: Mozambican authorities; and IMF staff estimates and projections. 
Figure 1. Mozambique: Macroeconomic Developments

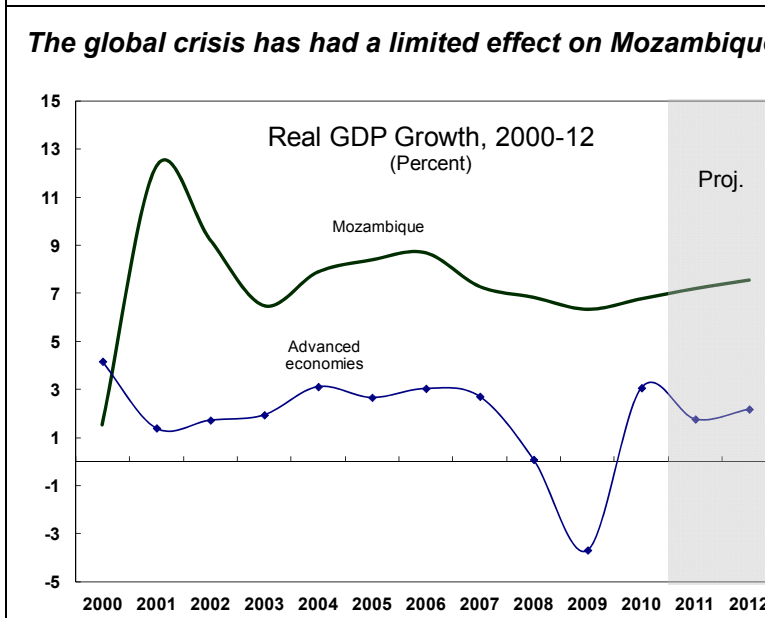

Inflation declined significantly in 2011, reflecting moderating food price inflation,...

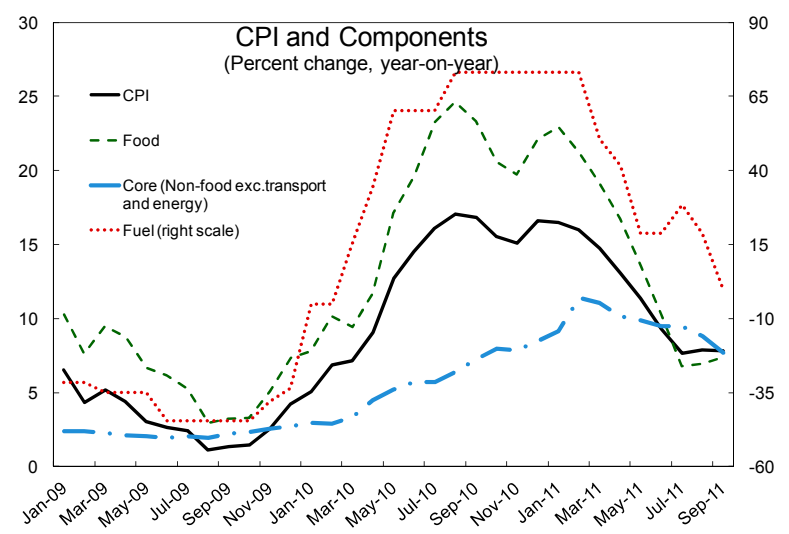

... although trend growth has declined in recent years.

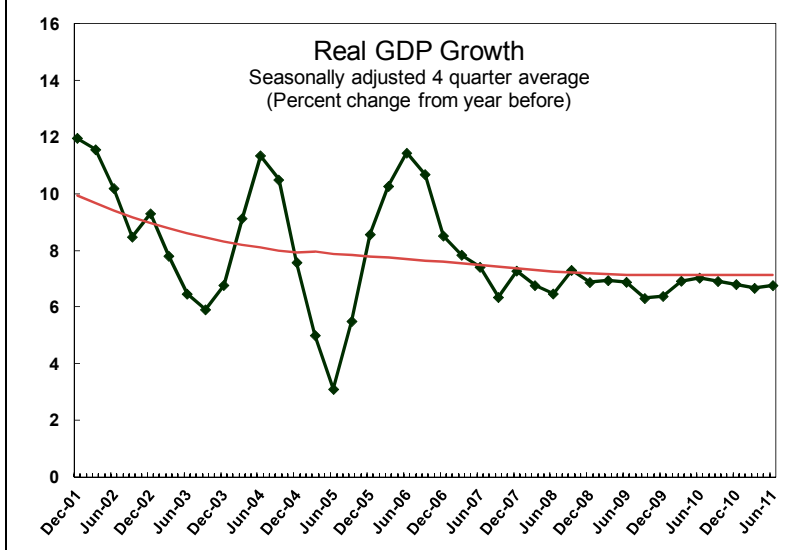

... determined monetary tightening,...

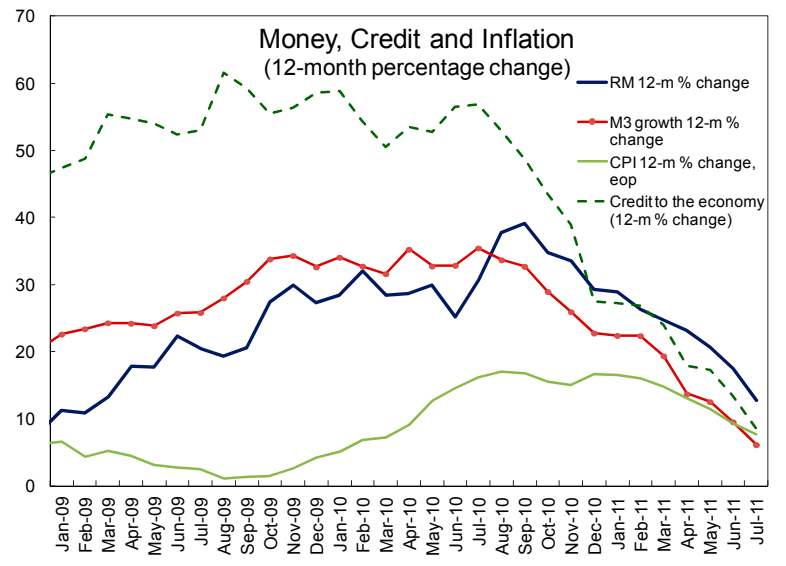

...and the continued appreciation of the metical.

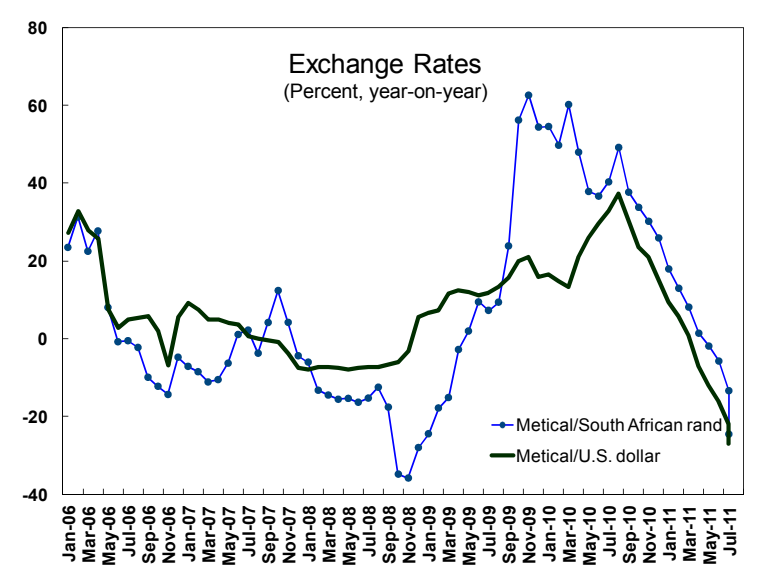

The market started to prefer T-bills with longer maturities, suggesting moderating inflation expectations.

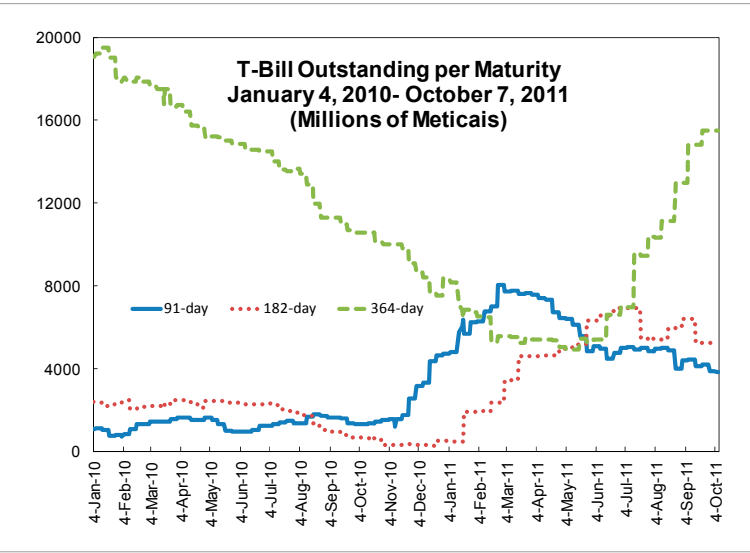

Sources: Mozambican authorities and IMF staff estimates and projections. 
Figure 2. Mozambique: Resilience to Global Crises

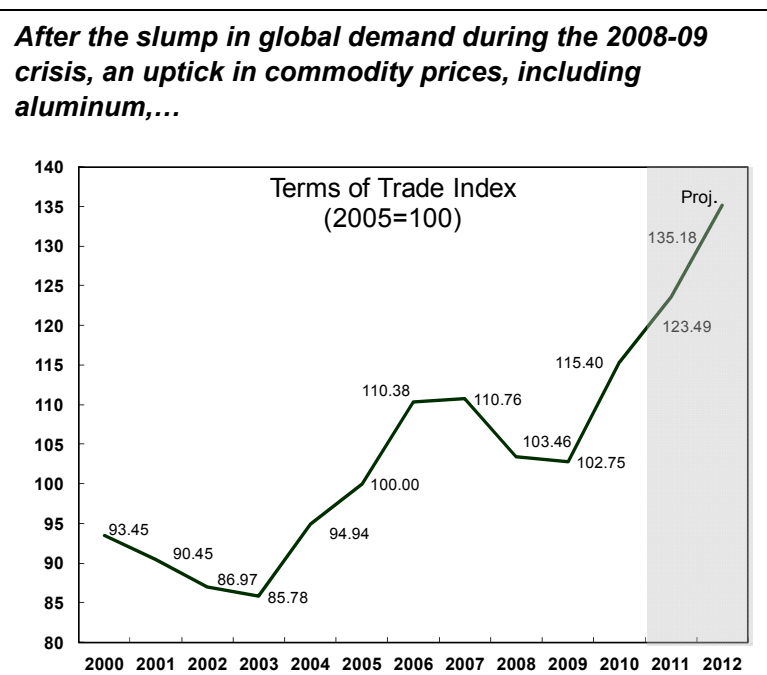

...as well as the coming online of new megaprojects, are expected to result in a recovery of export receipts to the pre-crisis level by 2011.

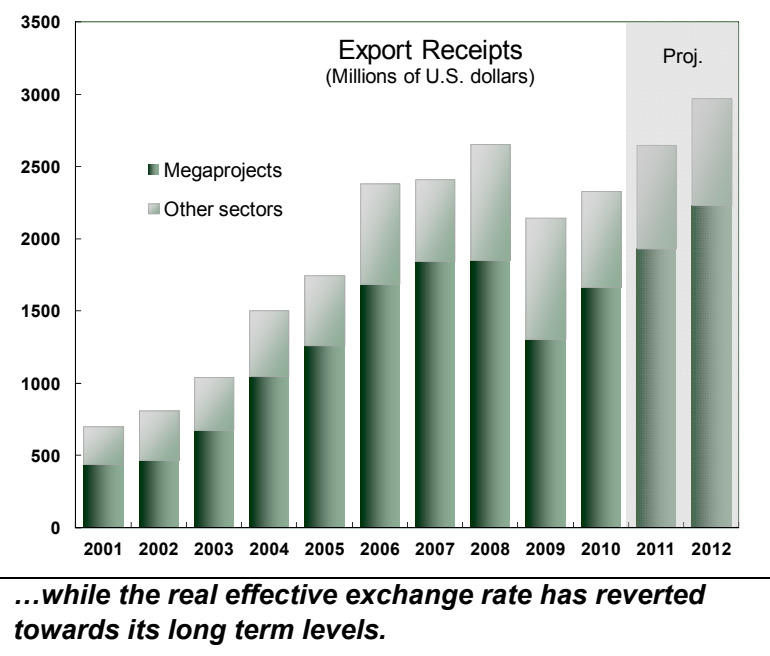

Mozambique's traditional export sectors are recovering, after lagging in recent years mainly due to the weak business environment and marketing problems,...

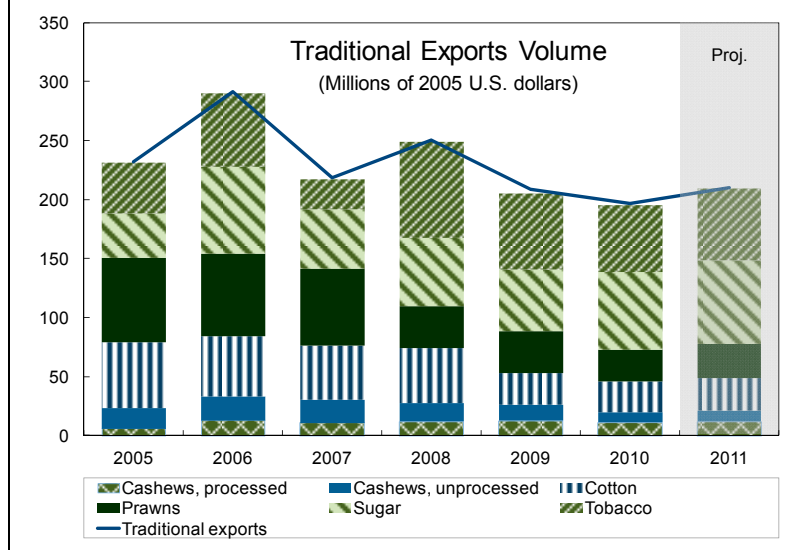

The current account is showing resilience in spite of the difficult external environment,...
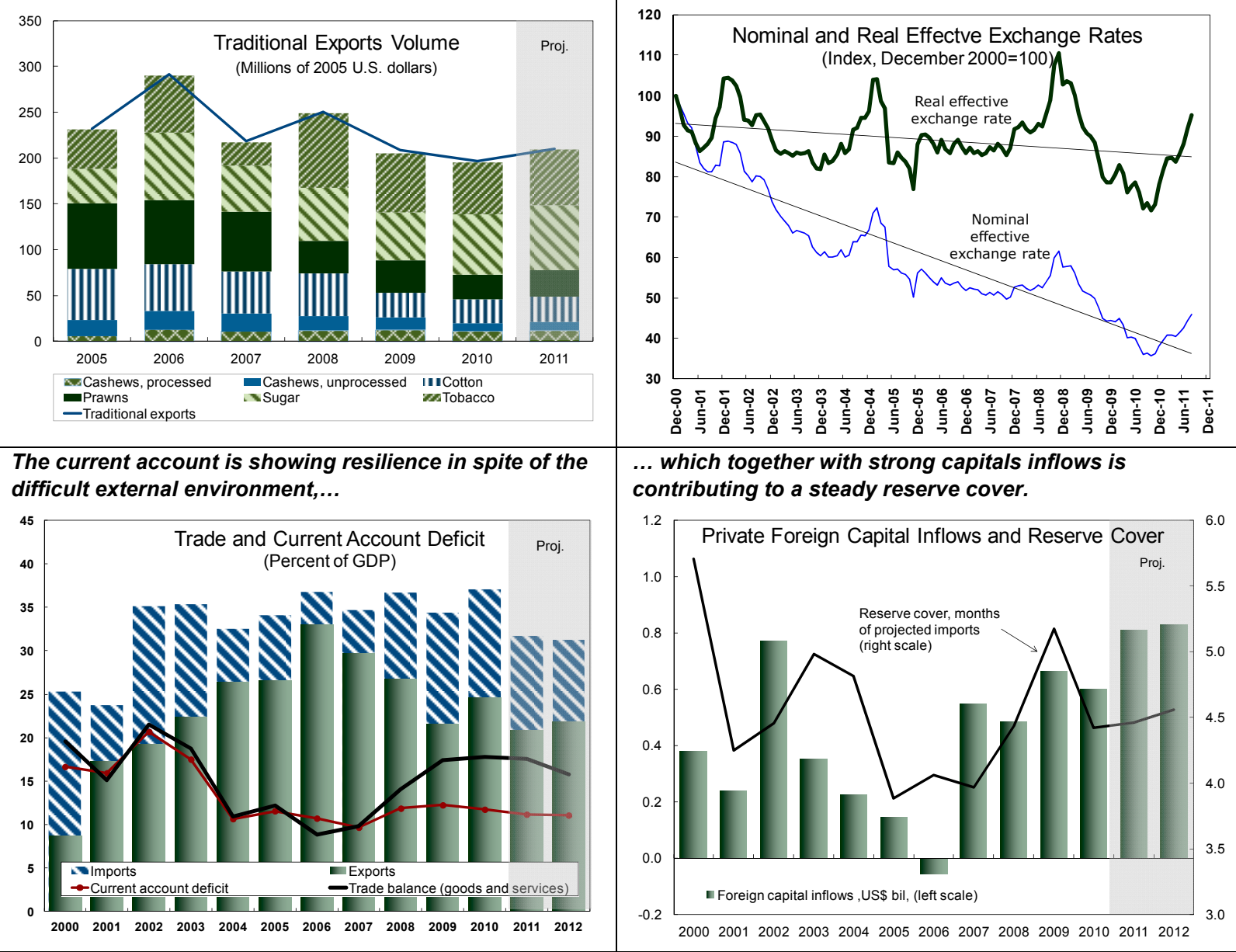

Sources: Mozambican authorities and IMF staff estimates and projections. 
Figure 3. Mozambique: Regional Comparison

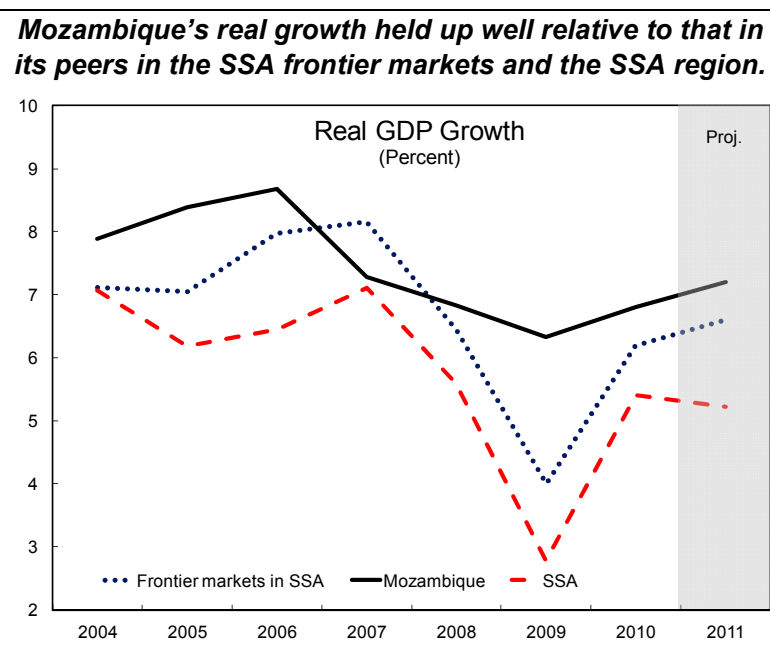

Inflation surged above the regional levels in 2009/10, although it is declining again in 2011.

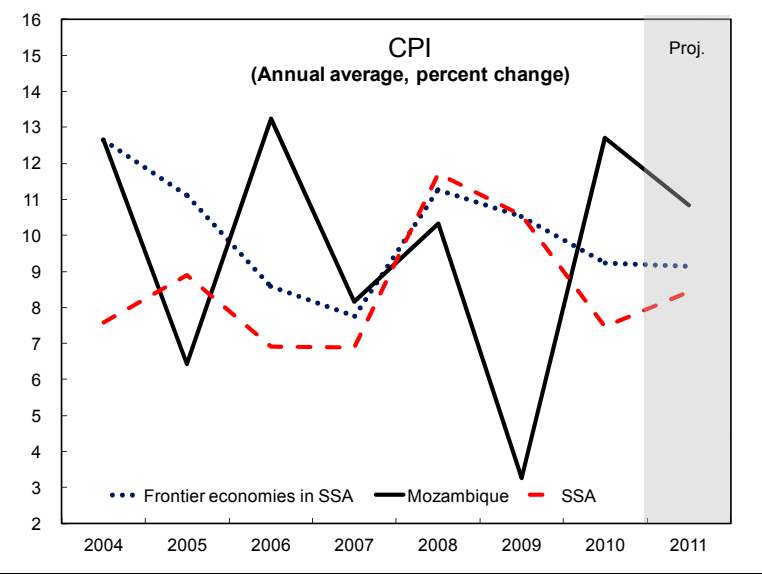

Mozambique's fiscal position has been similar to its peers in recent years.

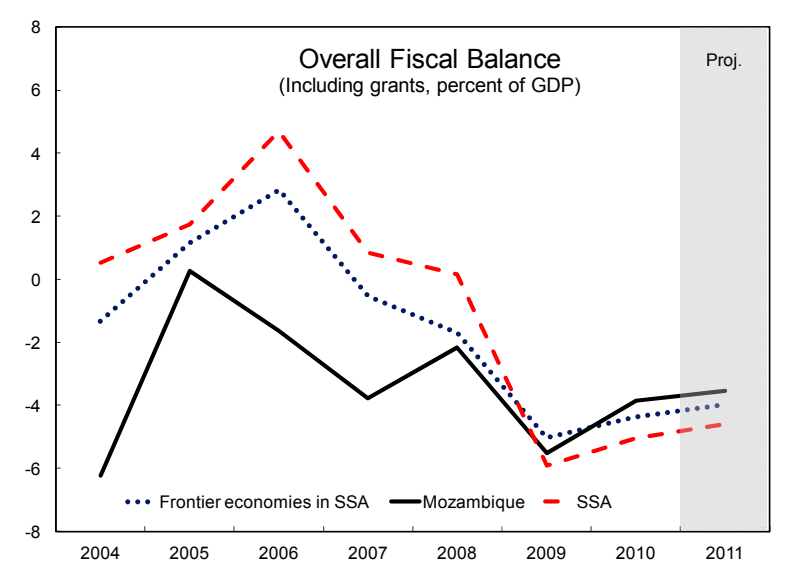

Credit expansion is slowing as a result of the recent monetary tightening, while still above its peers.

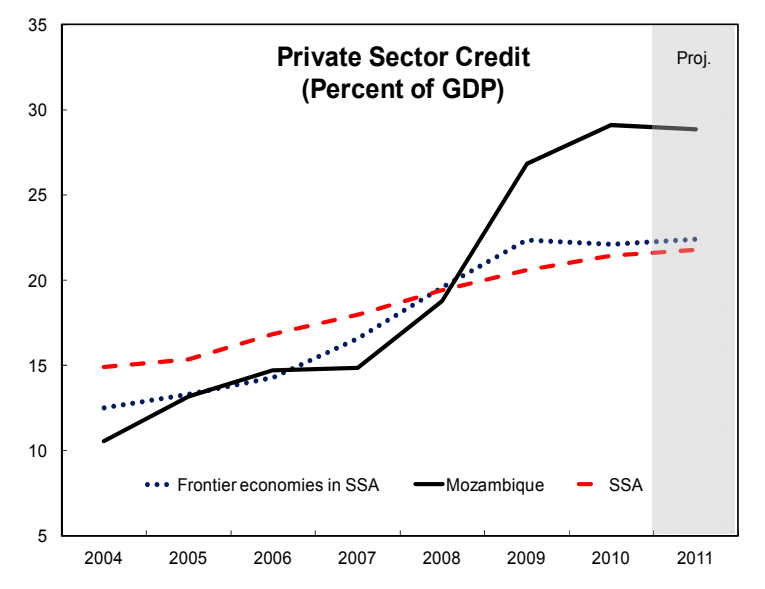

Mozambique's current account deficit was less affected by the global crisis than that of its peers.

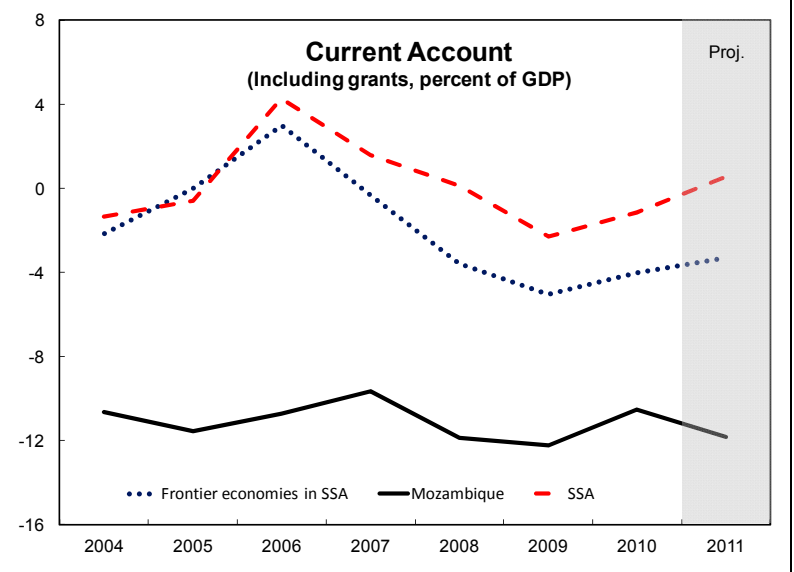

Reserves remained similar to other frontier economies, and at more comfortable levels than elsewhere in SSA.

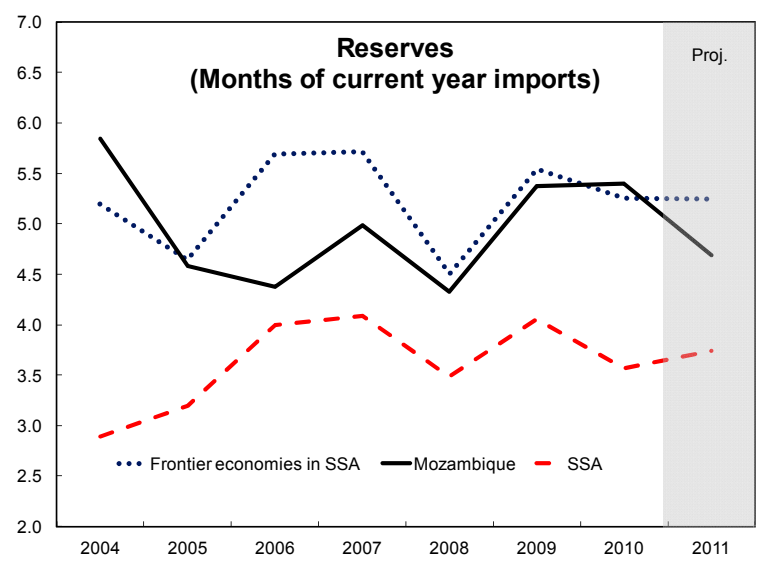

Sources: Mozambican authorities and IMF staff estimates and projections.

Frontier economies: Angola, Ghana, Kenya, Mauritius, Mozambique, Nigeria, Senegal, Tanzania, Uganda and Zambia 


\section{Performance Under the PSI And Policy Challenges}

Mozambique's record under the PSI remains strong. The authorities' policy mix aims to support macroeconomic stability and accommodate spending needs for growth-enhancing investment, social development, and possibly shock mitigation. To ease this task, the authorities seek to create fiscal space-by further increasing the revenue base and prudently expanding their NCB and domestic borrowing-while better prioritizing spending, upgrading natural resource management, and putting in place better targeted social support mechanisms.

\section{A. Performance Under the PSI}

5. All the quantitative program targets for end-June 2011 were met, except the AC on RM which was exceeded marginally. While RM growth was negative in the first half of 2011 and, until May, was on a path to allow meeting the end-June AC, some spikes in bank reserves in June ${ }^{2}$ and the seasonal strong demand for currency brought average RM above its targeted ceiling. However, end-month RM growth, at 171/2 percent, was broadly in line with the envisaged end-month target underlying the macroeconomic framework. RM growth deceleration continued in the third quarter, and the indicative target for end-September was met comfortably. Buoyant revenue collections and a prudent fiscal policy stance allowed the

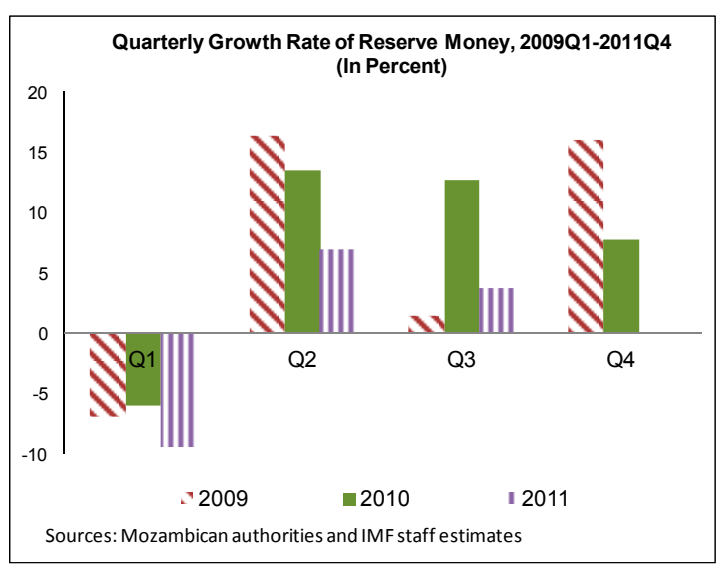
Government to meet the program targets on revenue and net credit to the government (NCG) by a large margin. Delays in donor project aid resulted in the non-observance of the quarterly indicative floors on priority spending, but the authorities are confident that the unchanged annual target would be achieved.

6. The authorities complied with structural conditionality. The end-July structural benchmark on the launch of the civil service and wage payment database was met. The benchmark on the submission of the anti-corruption legislation to Parliament was observed by end-October instead of end-July; this high-quality piece of legislation-based on the assessment of an external consultant presented to development partners - was approved by Cabinet on time, but repackaging some measures and completing their costing took more time than anticipated.

\footnotetext{
2 This was the result in particular of (i) purchases of foreign exchange that the BM had to undertake to curtail banks' excessive net foreign exchange open positions, and (ii) high demand for the central bank's lending facility by banks to allow meeting the reserve requirements.
} 


\section{B. ShORT-Term ChaLlenge: CURBing Inflation}

\section{Monetary Policy}

7. The authorities remain determined to further reduce inflation. Their objective is to contain end-of-period inflation to 81/2 percent in 2011 and below 6 percent in 2012, barring any unforeseen exchange rate pressures or commodity price spikes.

8. The $\mathbf{B M}$ is committed to keeping monetary expansion under close control. In 2011, it aims to contain RM growth to 13 percent, slightly tighter than envisaged at the second review. Going forward, in tandem with the authorities' progress in combating inflation, RM growth will gradually accelerate and expand MEFP $99-10$ slightly above nominal GDP growth to enable more private sector credit growth and support financial deepening (Figure 4). The strengthening of coordination with the Government will allow the BM to improve its liquidity forecasting and more effectively steer monetary conditions.

9. The BM is building capacity to move toward inflation targeting. Supported by IMF technical assistance (TA), it has made progress in collecting and analyzing data, developing forecasting techniques, and setting the stage for more transparent and efficient communication aimed at anchoring price expectations. In this context, the BM will publish its first quarterly monetary policy report in May 2012 (structural benchmark). The policy document is expected to cover a broad range of issues, MEFP १10-11 such as the international policy environment, the domestic economic activity and outlook, and an analysis of policy developments. In addition, the authorities seek to enhance the effectiveness of money market operations, develop domestic financial markets, and improve the liquidity of government securities. As an important first step in this regard, based on TA recommendations, they will equalize the tax treatment of various government securities and between collateralized and uncollateralized interbank market operations by end-September 2012 (structural benchmark).

\section{Fiscal Policy}

10. The fiscal deficit is likely to be smaller than expected in 2011. Based on buoyant revenues, the domestic primary deficit will be kept close to 3 percent of GDP, while lower spending on NCB-financed projects will result in a noticeably lower overall fiscal deficit than initially programmed. The NCG

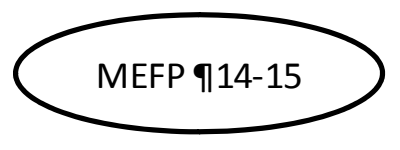
will be slightly higher than planned — but still be well contained - due to a shift in budget support between 2011 and 2012 agreed upon with two donors.

\section{In 2012, a looser fiscal stance will} accommodate the authorities' public investment and social development plans. The overall fiscal deficit will rise from $3 \frac{1}{2}$ to $5 \frac{3}{4}$ percent of GDP,

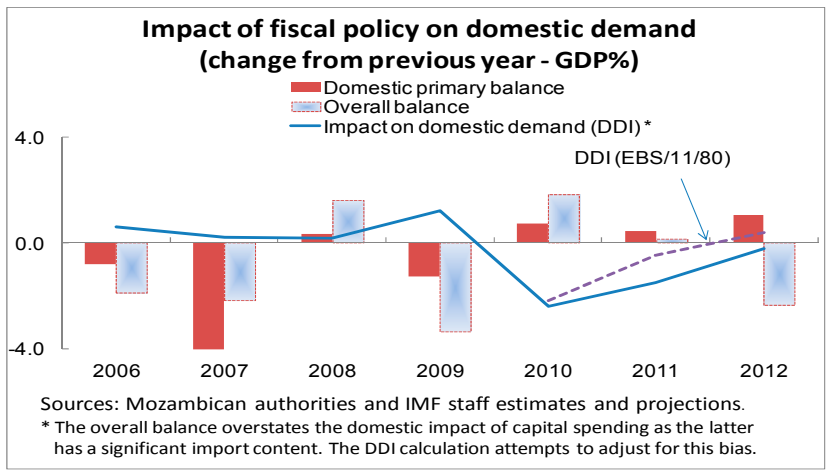


reflecting in particular a pick-up in externally-financed infrastructure investment and additional resources allocated to social protection under the 2012 budget relative to 2011 (see below). However, current expenditure is expected to be restrained in real terms. The execution of the budget will remain subject to the revenue contingency under the organic budget law which caps budget execution as long as revenue collections remain uncertain. As revenue performance is expected to remain strong, this will result in a decline of the domestic primary fiscal deficit by about 1 percentage point, to 2 percent of GDP, mitigating the impact on inflation (Figure 5).

\section{Medium-Term Challenge: Creating Fiscal SpaCe for More Inclusive Growth}

\section{Policy Mix}

12. Over the medium term, the authorities are determined to accelerating public investment and spending more on social support mechanisms. While monetary policy will continue to be geared toward achieving low levels of inflation, fiscal policy will aim to step up public investment to close the MEFP १17-18 infrastructure gap (which hampers long-term growth) and support an expansion of the social safety nets to address chronic poverty. ${ }^{3}$ The authorities reaffirmed their commitment to expand public investment on a path that is consistent with safeguarding macroeconomic stability and debt sustainability over the medium term.

\section{Constraint}

13. Mozambique is likely to face a leveling off in net aid flows. Donor support has been key to providing resources for the country's development needs in a sustainable way. Net aid flows have already significantly declined from the global crisis-related peak of $14 \frac{1}{2}$ percent of GDP in 2009 to $12 \frac{1}{2}$ percent of GDP in 2010, and are projected to level off to below 10 percent of GDP from 2011 onward, reflecting a reorientation among some donors and the rapid growth of Mozambique's GDP. Furthermore, donors tend to increasingly condition general budget support on performance, particularly in the governance area, and to shift support toward sectoral or project support, which may complicate the predictability of budget execution. These trends may force the authorities to revisit their development and poverty reduction financing strategy.

\section{Revenue Effort}

\section{Government revenues are set to make a major contribution to creating the} necessary fiscal space for more inclusive growth but need to become more diversified. Tax revenues have continuously increased at a strong pace over the past five years, boosting the revenue/GDP ratio from

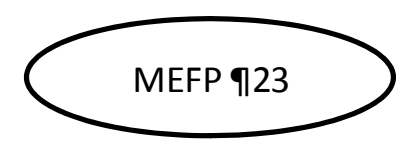
15 percent to $21 \frac{1}{2}$ percent in 2011 . The authorities are committed to maintaining their tax

\footnotetext{
${ }^{3}$ For an analysis of the lack of inclusive growth in Mozambique, see IMF Country Report No. 11/149, particularly Appendix III.
} 
Figure 4. Mozambique: Monetary and Financial Sector Developments

Reserve money was slightly above the end-June program target but well below the end-September indicative target.

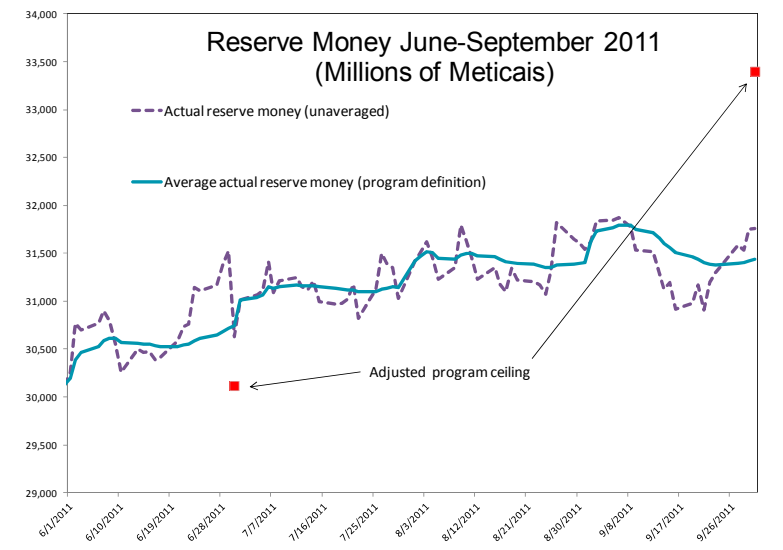

The BM tightened monetary conditions in 2010-11 by raising its policy rates and reserve requirements (before lowering them slightly in August)...

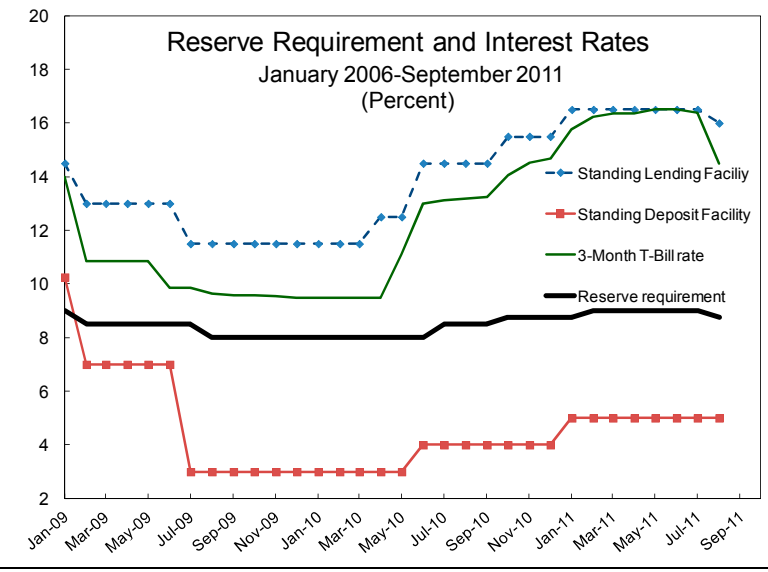

The expansion of monetary aggregates pursued in the wake of the global crisis was thus reverted in $2011 .$.

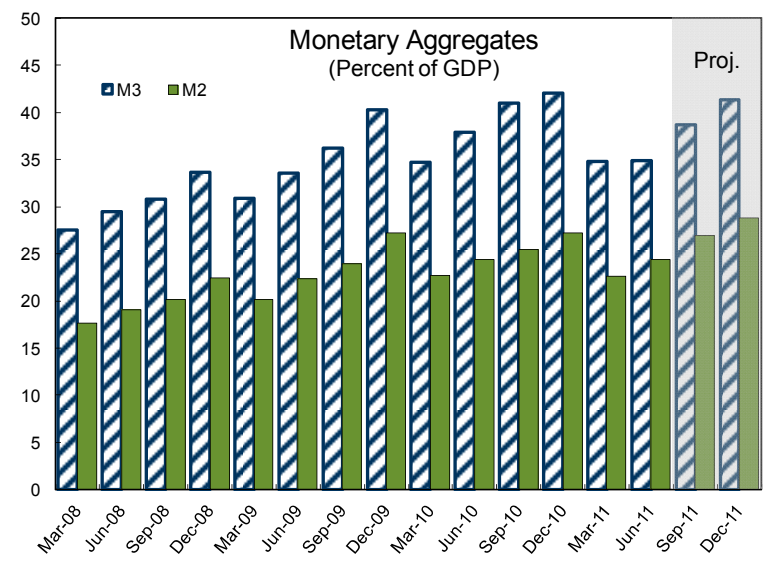

Unlike the situation at end-2010, cash in circulation was more stable, which may suggest some improvement in fiscal-monetary coordination and liquidity forecasting.

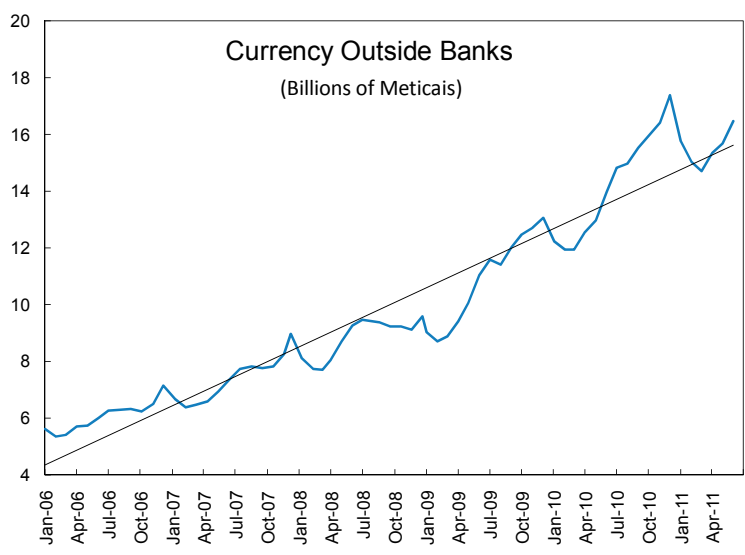

....and used its open market operations to mop up liquidity.

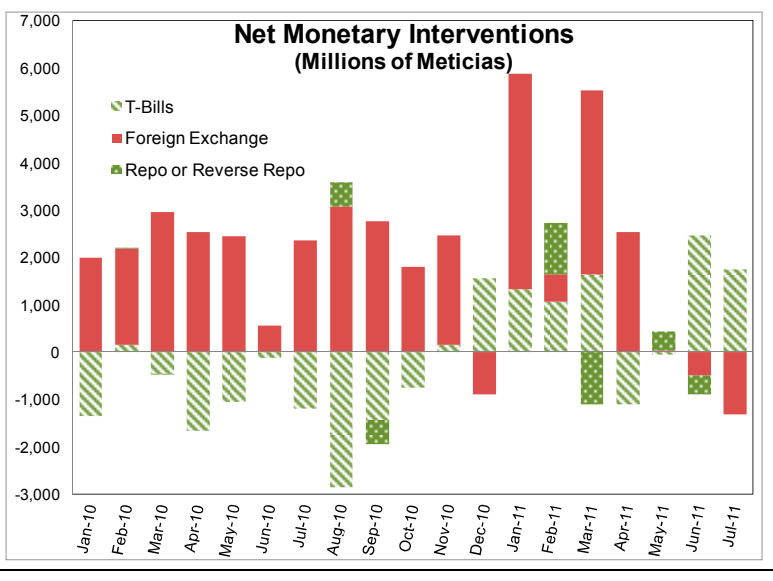

...while private sector credit eased sharply as a share of GDP.

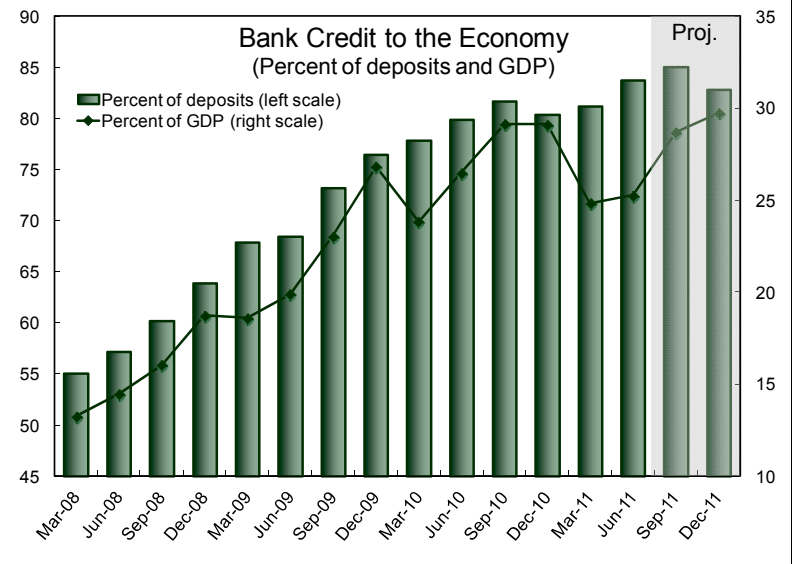

Sources: Mozambican authorities and IMF staff estimates and projections. 
Figure 5. Mozambique: Fiscal Developments

The wage bill and transfers-especially for the fuel subsidy-put pressures on domestic spending.

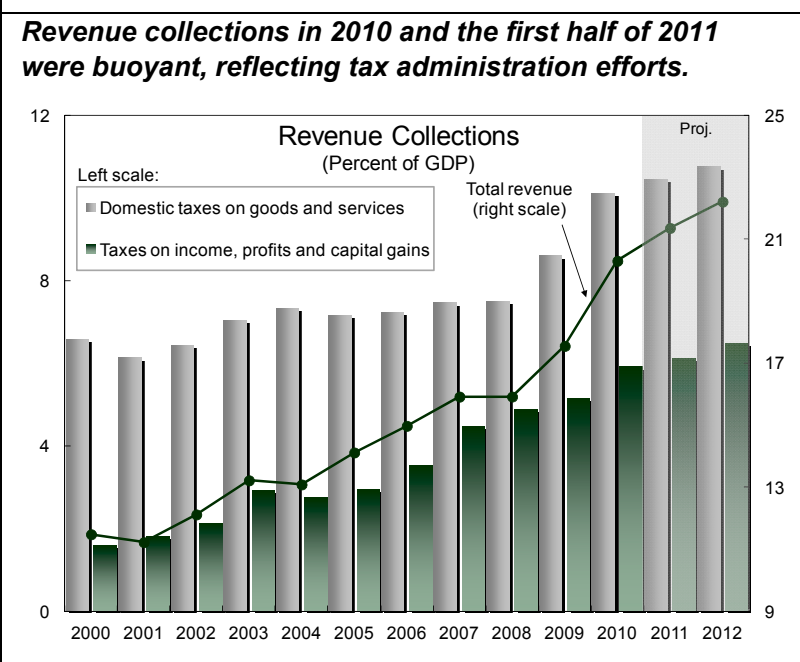

were buoyant, reflecting tax administration efforts.

The domestic primary deficit was contained in 2010 and is expected to shrink further.

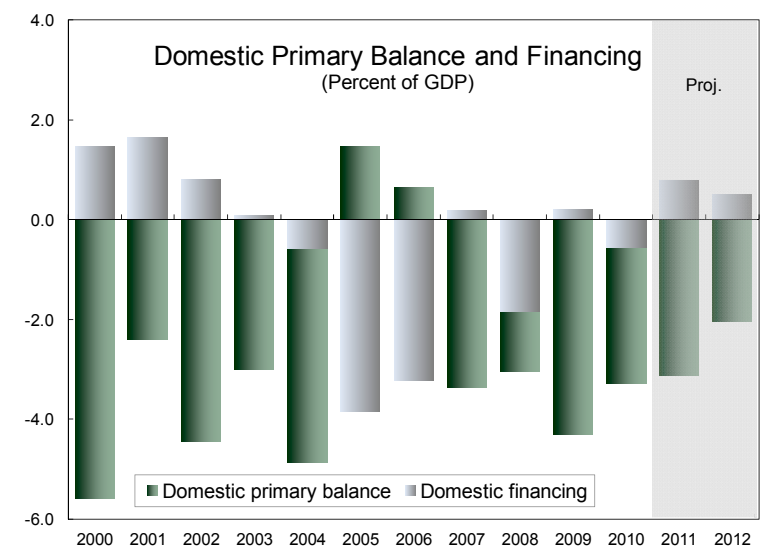

\section{...external budget support has so far helped limit the} need for domestic financing.

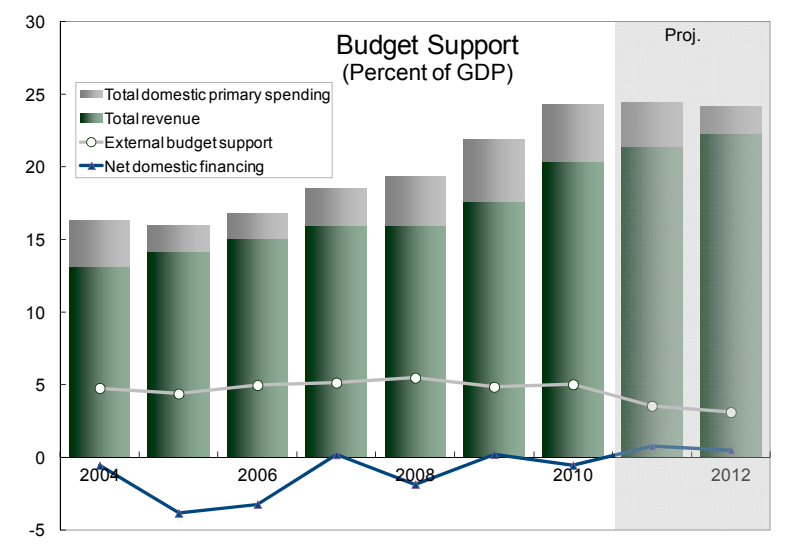

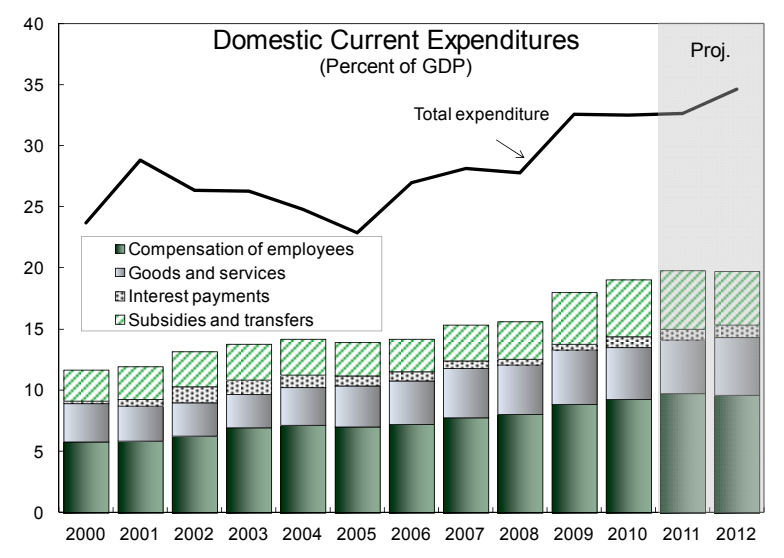

Capital spending relies heavily on external project support which has been on a declining trend, while...

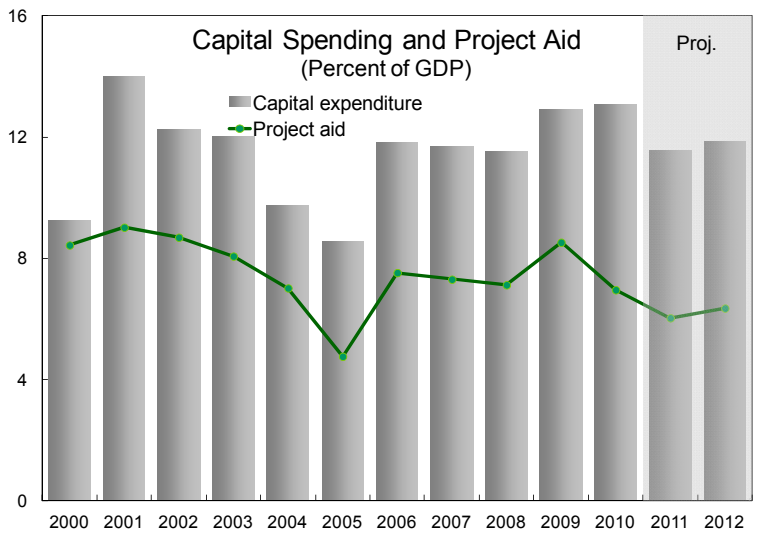

Net credit to government met the program target comfortably.

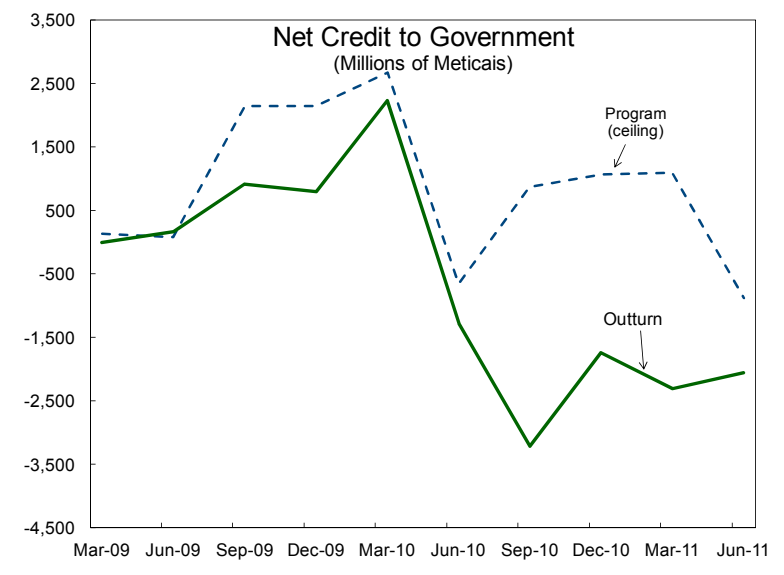

Sources: Mozambican authorities and IMF staff estimates and projections. 
administration effort while making the tax system more business-friendly through several structural measures. This is expected to raise revenue performance to $23 \frac{1}{2}$ percent of GDP over time. Among other things, the authorities will introduce by end-June 2012 a new single taxpayer and identification number that will enhance the efficiency of tax administration (structural benchmark).

\section{However, the increase in revenues seen in the recent past will not be sustained} absent additional sources of income, especially from the booming natural resource sector

(Box 1). To this end, the authorities intend to revisit the sector's fiscal regime, based on IMF TA likely to take place in early 2012 under the new Topical Trust Fund for Managing Natural Resource Wealth (TTF-MNRW). They are also reviewing existing contracts with investors in the sector to assess the scope of an amicable renegotiation that would bring the sector's tax contributions in line with the MEFP $\mid 24-25$ new fiscal regime. In the process, they will carefully balance the aim to raise revenues with the need to preserve Mozambique as a destination for FDI. Staff also advocated the creation of special fiscal institutions, such as a stabilization fund, that could enhance the authorities' capacity to use large additional revenue and adjust short-term spending to inter-temporal revenue flows, while supporting investment plans. This would be critical to ensure external competitiveness and the diversification of the economy. Finally, the authorities will expedite their efforts to become a full-fledged member of the EITI in the near future, but no later than the target date set by the EITI of February 2013.

\section{Borrowing Strategy}

\section{The authorities' recourse to NCB is likely to rise but will remain consistent with} macroeconomic stability and debt sustainability. The cumulative NCB ceiling of US\$900 million under the three-year program has so far been prudently used for two loans totalling US\$146 million for two airport projects. The financing of other large infrastructure projects, including the port of Beira and hydro-electricity projects, is being considered and, given the projects' size, could rapidly bring Mozambique's nonconcessional contractual debt closer to the program ceiling. Nonetheless, the authorities are committed to pacing actual project implementation - including under the Portuguese credit line — such that it is consistent with the country's macroeconomic circumstances.

\begin{tabular}{|c|c|c|c|c|c|c|c|c|}
\hline & 2009 & 2010 & 2011 & 2012 & 2013 & 2014 & 2015 & 2016 \\
\hline \multicolumn{9}{|c|}{ (Percent of GDP) } \\
\hline Total & 12.9 & 14.4 & 14.0 & 15.1 & 15.5 & 15.1 & 14.8 & 14.2 \\
\hline On budget & 12.9 & 13.1 & 12.0 & 13.7 & 14.5 & 14.3 & 14.2 & 14.2 \\
\hline Domestically financed & 4.4 & 6.1 & 5.5 & 5.5 & 6.0 & 6.0 & 6.1 & 6.3 \\
\hline Donor financed, concessional & 8.5 & 7.0 & 6.0 & 6.3 & 6.4 & 6.4 & 6.4 & 6.4 \\
\hline Non-concessional & 0.0 & 0.0 & 0.4 & 1.8 & 2.1 & 1.9 & 1.7 & 1.5 \\
\hline Credit line from Portugal $1 /$ & 0.0 & 1.4 & 2.0 & 1.4 & 1.0 & 0.8 & 0.7 & 0.0 \\
\hline Concessional & 0.0 & 1.4 & 1.3 & 0.7 & 0.4 & 0.3 & 0.2 & 0.0 \\
\hline Nonconcessional & 0.0 & 0.0 & 0.7 & 0.6 & 0.6 & 0.5 & 0.4 & 0.0 \\
\hline \multicolumn{9}{|l|}{ Memorandum items: } \\
\hline Total concessional and domestic & 12.9 & 14.4 & 12.9 & 12.6 & 12.8 & 12.6 & 12.7 & 12.6 \\
\hline Total nonconcessional & 0.0 & 0.0 & 1.1 & 2.5 & 2.7 & 2.4 & 2.1 & 1.5 \\
\hline
\end{tabular}




\section{Box 1. Natural Resource Management and Growth}

Mozambique's natural resource reserves are still largely unexploited. Its diverse geology offers a wide range of minerals and metals, including coal, natural gas, mineral sands, and potentially oil. With the starting of operations of the coal projects in Tete (central Mozambique) and the upcoming expansion of natural gas production, the natural resource sector is set to boom in the near term.

Consistent with past experience, natural resources are likely to make a substantial contribution to economic growth and exports going forward. Preliminary estimates suggest that megaprojects can directly contribute up to 18 percent of total value added by 2016 and boost economic growth by 2 to 4 percentage points annually. ${ }^{1}$ In the same vein, they are likely to increase their share in total exports, which already now accounts for 70 percent. By contrast, they are unlikely to provide a boost to employment, given their capital intensity.

With a higher contribution to government revenues, the sector could allow to decisively step-up pro-growth spending over the long run.

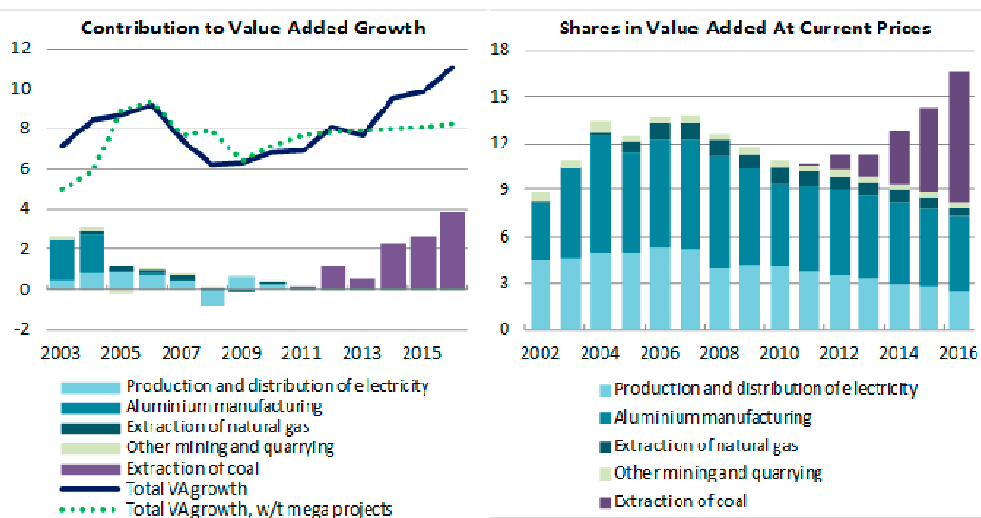

Megaprojects' contribution to government revenues has been disproportionately low, at 3 to 4 percent during 2006-10. ${ }^{2}$ A more efficient fiscal regime, together with enhanced revenue forecasting and revenue diversification, could create significant space for pro-growth spending, including for social protection, over the long run.

${ }^{1}$ See Appendix II for an estimate of the direct impact of megaprojects on the growth of the total value added in the economy.

${ }^{2}$ See also IMF Country Report No. 11/149.

\section{Stepping up debt management and investment planning is pivotal to making good} use of NCB and improving spending efficiency. The authorities reiterated their commitment to intensify the modernization of their debt management and project selection procedures. Drawing on IMF TA and MEFP $\mid 21-22$ World Bank capacity training, they will complete their medium-term debt strategy and second debt sustainability analysis such that they can be submitted for Cabinet approval in the first quarter of 2012. They are also set to develop an annual domestic borrowing plan and strengthen project selection processes. Staff concurred with the authorities' request to delay the completion of the structural benchmark on the Integrated Investment Plan from end-2011 to end-March 2012 to allow key ministry officials to benefit from World Bank training on project selection.

\section{Prioritization of Spending}

\section{Current spending allocations will be better prioritized. In}

particular, the authorities aim to phase out the ill-targeted and costly fuel subsidy and replace it with more efficient subsidies and social protection 
systems. The adjustments of diesel and gasoline prices in April and July by a cumulative 18 percent left only the diesel price subsidized, which they expect to end by early 2012. In early September 2011, consistent with the new four-year Poverty Reduction Strategy (PARP), Cabinet decided to launch the roll-out of a basic social protection initiative in 2012 , by revamping the cash transfer system and introducing a labor-intensive public works program in urban and rural areas, as devised under a pilot program with support from UNICEF, the ILO, the World Bank, the IMF, and bilateral partners. At the same time, they aim to further strengthen their handle on the wage bill, which had risen sharply toward the end of the last decade and triggered a strategic review of the civil service wage policy. In addition, based on the successful pilot of the civil service and wage database in selected provinces, the database will be rolled out to all provincial directorates by end-June 2012 (structural benchmark).

\section{Risks to The Program}

Risks to the program have increased, but appear manageable due to sound macroeconomic indicators, good policy implementation, and expected continued support by partners.

\section{Risks to the implementation of the program stem primarily from a potential global}

downturn. Mozambique could be affected through the same transmission channels as during the 2008/09 crisis-lower trade and lower access to international finance. Additional risk factors could now also emanate from lower aid flows and the indirect exposure of the banking system to the sovereign debt and banking crisis in the euro area. Though current indications point to no immediate concerns in these areas, policy options should be preventively considered to thwart these risks (Box 2).

\section{Mozambique is well positioned to mitigate the impact of a temporary global}

downturn. The overall sound macroeconomic indicators and the prudent policy mix over the last few years - including the timely tightening of monetary policy to fight inflation — should facilitate the authorities' policy response should external conditions deteriorate. In such an environment, should external funding sources for the private sector dry up like during the 2008/09 global crisis, progress in containing inflation could justify a more accommodating monetary policy stance. Fiscal policy should continue to be guided by medium-term considerations, including maintaining planned priority spending to the extent possible; the more accommodating monetary policy stance could compensate, at least partially, shortfalls in donor support through higher domestic financing, to the extent that this can be done without crowding out private sector credit. At the same time, the authorities could allow automatic stabilizers to operate temporarily on the revenue side. 


\section{Box 2. The Impact of the European Crisis}

The euro area crisis has not had any major adverse impact on the Mozambican economy thus far, and its effects appear circumscribed to the relations with Portugal.

- Aid commitments have largely been confirmed for 2012. Although most European countries face intense budget constraints, any future change in aid volume or modalities is more likely to be the result of ongoing policy reorientations among donors or their concerns on governance and the implementation of the PARP than the direct impact of the sovereign and banking crisis. ${ }^{1}$ In any case, continued aid will be crucial in the event of a sharp downturn to support economic development.

- Public investments from Portugal have slowed. The first disbursement under the nonconcessional Portuguese credit line to build road infrastructure was delayed to October 2011. Disbursements under the credit line's concessional window have occurred at a slower pace than initially envisaged. In addition, the National Investment Bank set up by the Mozambican and Portuguese governments has begun to operate in June 2011, but only with a small fraction of the originally planned capital.

- The banking sector has generally remained resilient to the crisis. ${ }^{2}$ Most foreign-owned Mozambican banks benefited from a substantial capital increase earlier this year. Together with a slowdown in credit activity, this has sharply raised the system-wide capital adequacy ratio to 18.7 percent at end-June 2011. The Mozambican subsidiaries remain a source of operating income for their Portuguese parents. The appreciation of the Metical vis-à-vis the Rand has increased the profitability of the South African subsidiaries within their groups.

- Nonetheless, tight liquidity conditions resulting from the BM's disinflation policy and funding pressures of parent banks led to a reduction in risk taking and curtailed credit growth. The two largest Mozambican banks (which account for 60 percent of the banking system's assets) are owned by the three major Portuguese financial institutions that experienced funding pressures through their exposure to European sovereign risks. An analysis of aggregate intra-group crossborder flows suggests that large Mozambican banks which traditionally maintained substantial deposits in parent banks have curtailed their intragroup exposure over the past few months, thus reducing vulnerabilities.

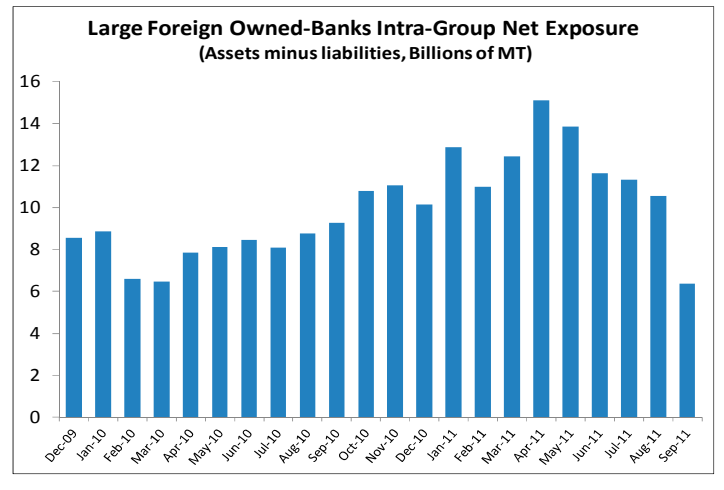

${ }^{1}$ On governance concerns, see Box 1 in IMF Country Report No. 10/174.

${ }^{2}$ Results of stress tests on the banking system are presented in Appendix IV of IMF Country Report No. 11/149.

\section{The completion of the comprehensive financial sector contingency plan under the} program would help the authorities cope with a worst-case scenario. The authorities have already implemented the modules to put into motion prompt corrective actions in case of a banking crisis and to strengthen MEFP 130 coordination with foreign supervisors. In addition, they are contemplating stronger limits on concentration of intra-group deposits, so as to limit cross-border contagion risks. 


\section{Spillovers from economic developments in South Africa need to be monitored} closely. This is notably the case of possible sharp exchange rate swings. As imports from South Africa account for one-third of total imports, the bilateral exchange rate is a key determinant of price developments in Mozambique, particularly for food products. It also weighs on imports of South African intermediate goods for infrastructure projects. On the export side, the exchange rate impacts revenues from electricity exports to South Africa (about 12 percent of total exports), since the contracts are Rand-denominated. Additional risks emanate from the high volatility of capital flows to emerging economies and the possible effect of a weaker South African economy on FDI inflows.

\section{Program Monitoring}

23. Modifications are proposed for several ACs for end-December 2011 and the RM adjuster. The ACs on NCG, RM, and NIR were adjusted according to performance to date and the authorities' short-term policy objectives. Going forward, in light of the BM's improved forecasting capacity, it is proposed to reduce the adjuster for the RM targets, which applies whenever the actual stock of currency in circulation exceeds the level envisaged in the program. The adjuster will be capped to MT 250 million for end-March, end-June, end-September and end-December 2012, and will be discontinued thereafter.

\section{It is proposed to discontinue the continuous structural benchmark that limits the} use of NCB to spending in energy and transportation infrastructure. The authorities' progress in strengthening debt management capacity, and the prudent use of NCB, have made this benchmark unnecessary. The authorities welcomed this recognition of their track record of prudent borrowing decisions and reforms, although they reaffirmed their strategy to continue to focus NCB on investment in energy and infrastructure.

25. Structural conditionality will be in the areas of Fund expertise. Staff and the authorities agreed to structural conditionality in the areas of tax administration and policy, the monetary policy framework, and public financial management. 
Structural Conditionality, 2012

\begin{tabular}{|c|c|c|}
\hline Measure & $\begin{array}{l}\text { Expected Date of } \\
\text { Implementation }\end{array}$ & Macrorelevance \\
\hline $\begin{array}{l}\text { The Minister of Planning and Development will approve an Integrated } \\
\text { Investment Program, in consultation with the Project Coordination } \\
\text { Committee, as described in paragraph } 25 \text { of the MEFP dated May } 20 \text {, } \\
2011 .\end{array}$ & End-March $2012^{1}$ & $\begin{array}{l}\text { Improve efficiency of public investment, } \\
\text { thereby supporting growth and debt } \\
\text { sustainability. }\end{array}$ \\
\hline $\begin{array}{l}\text { The Bank of Mozambique will publish its first quarterly monetary } \\
\text { policy report, as described in paragraph11 of the attached MEFP. }\end{array}$ & End-May 2012 & $\begin{array}{l}\text { Enhance transparency and accountability of } \\
\text { monetary policy, thereby better anchoring price } \\
\text { expectations and facilitating the transition to } \\
\text { inflation targeting. }\end{array}$ \\
\hline $\begin{array}{l}\text { The Government will complete the rollout of the e-Folha electronic } \\
\text { salary payment system to all provincial directorates, as described in } \\
\text { paragraph } 19 \text { of the attached MEFP. }\end{array}$ & End-June 2012 & $\begin{array}{l}\text { Improve budget planning and execution, and } \\
\text { enhance the authorities' handle on the wage } \\
\text { bill. }\end{array}$ \\
\hline $\begin{array}{l}\text { The Ministry of Finance will make fully functional a new single } \\
\text { taxpayer database and identification number, as described in } \\
\text { paragraph } 23 \text { of the attached MEFP. }\end{array}$ & End-June 2012 & $\begin{array}{l}\text { Help create fiscal space and shore up } \\
\text { authorities' revenue objectives. }\end{array}$ \\
\hline $\begin{array}{l}\text { The Government will submit to Parliament an amendment to the } \\
\text { Corporate Income Tax Law reflecting measures derived from an } \\
\text { impact study on the equalization of the tax treatment between } \\
\text { Treasury bills and Government bonds and between collateralized and } \\
\text { uncollateralized interbank market operations, to take effect in } 2013 \text {, } \\
\text { as described in paragraph } 10 \text { of the attached MEFP. }\end{array}$ & End-September 2012 & $\begin{array}{l}\text { Enhance the effectiveness of money market } \\
\text { operations, develop domestic financial } \\
\text { markets and improve the liquidity of } \\
\text { government securities. }\end{array}$ \\
\hline
\end{tabular}

${ }^{1}$ Proposed to be delayed from end-December 2011 to allow officials in the Ministry of Plan and Development and line ministries to benefit from World Bank capacity building training on project selection.

\section{Staff Appraisal}

26. Mozambique's economic performance remains strong. The tightening of monetary policy in 2011 has been effective in curtailing inflation and had no adverse repercussions on the buoyant and broad-based economic activity. The prudent execution of the 2011 budget has contributed to a judicious policy mix that has fostered the consolidation of macroeconomic stability at a critical juncture and positioned the country well to respond to downside risks should such a need arise.

\section{The authorities' determination to further reduce inflation is appropriate. Staff} supports the objective to contain end-of-period inflation to $8 \frac{1}{2}$ percent in 2011 and below 6 percent in 2012, which appears feasible absent adverse economic developments. Staff encourages the authorities to adjust macroeconomic policies if necessary to safeguard the inflation objective. The BM's intention to keep monetary expansion under close control, yet slightly above nominal GDP growth, should support financial deepening and an appropriate expansion of private sector credit. Strengthened coordination between the Government and the $\mathrm{BM}$ should allow the BM to further improve its liquidity forecasting and more effectively steer monetary conditions. The BM's work on the technical prerequisites to move, at the appropriate time, to an inflation targeting framework is welcome.

\section{Going forward, the focus of fiscal policy on fostering the country's infrastructure} and social development is welcome. With inflation on a downward trajectory and approaching the authorities' medium-term objectives, the authorities rightly envisage an increase in public investment and a gradual expansion of social protection systems from 2012 onwards to support 
the country's economic development and social cohesion. Nonetheless, while Mozambique's infrastructure gap is large, the authorities should continue to pace their development agenda in line with the need to preserve medium-term macroeconomic stability and debt sustainabilityconsistent with their strong track record to date in this area.

29. The envisaged creation of fiscal space to support the development agenda requires prudent policy decisions going forward. This is all the more important since donor support is likely to level off over time. The Government's intention to pursue their tax administration and policy reforms and work on various fronts towards a larger contribution of the natural resource sector to the revenue base is thus welcome. Staff recommends that the authorities consider the creation of a fiscal stabilization fund early on so as to lay the foundation for maintaining macroeconomic stability for the event that the increased revenue flows materialize. With respect to NCB, the authorities are encouraged to carefully assess their financing options and underlying projects so as to ensure an adequate economic return for this more expensive form of borrowing. In this context, modernizing debt management and strengthening investment planning and selection are critical structural reforms in order to further improve economic decision-making. In their project selection decisions, the authorities are encouraged to focus on the catalyzing role of public investment in crowding in private investment and promoting domestic trade and employment.

30. In the same vein, further improvements in prioritizing current spending are critical to help the authorities meet their social development objectives. The Government's steps towards the phasing-out of the costly fuel subsidy are thus welcome. The authorities are advised to ensure adequate budgetary allocations for the envisaged expansion of the recently adopted social protection schemes. The success of these reforms will be a crucial, and visible, marker in the implementation of the social development strategy under the PARP.

31. Based on program performance and the authorities' strong ownership of the Fundsupported program, staff recommends completion of the third review under the PSI. Staff also recommends a waiver for the minor nonobservance of the end-June AC on RM, the modification of ACs, and the re-phasing of the structural benchmark on the Integrated Investment Plan. 
21

Table 1. Mozambique: Selected Economic and Financial Indicators, 2009-16

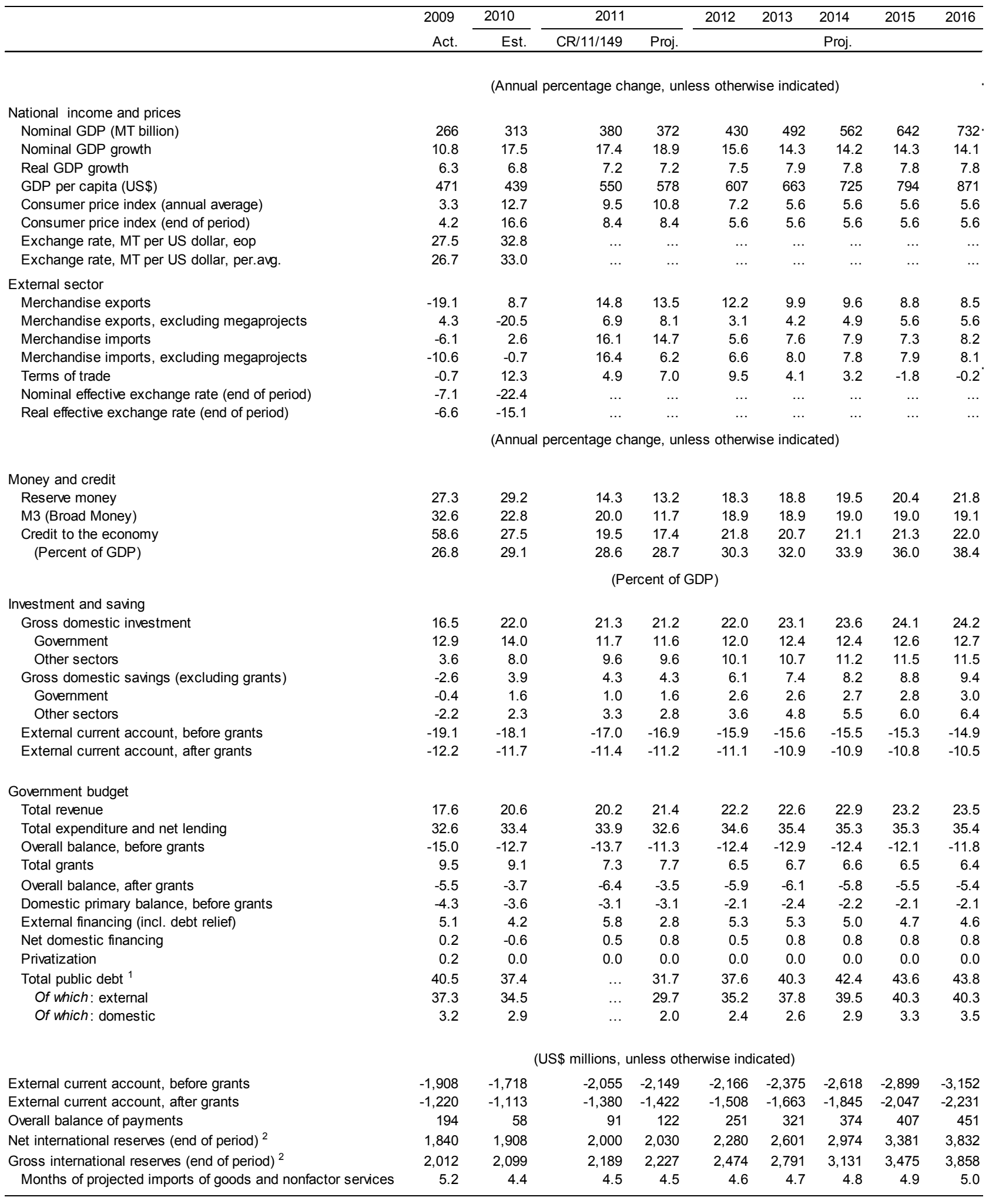

Sources: Mozambican authorities; and IMF staff estimates and projections.

${ }^{1}$ Consistent with DSA definition, the nonconcessional Portuguese credit line is included under the external debt.

${ }^{2}$ Includes disbursements of IMF resources under the ESF and August 2009 SDR allocation. 
Table 2. Mozambique: Government Finances, 2009-12

(MT Billions)

\begin{tabular}{|c|c|c|c|c|c|}
\hline & \multirow{2}{*}{$\begin{array}{l}2009 \\
\text { Act. }\end{array}$} & \multirow{2}{*}{$\begin{array}{c}2010 \\
\text { Est. }\end{array}$} & \multicolumn{2}{|c|}{2011} & \multirow{2}{*}{$\begin{array}{l}2012 \\
\text { Proj. }\end{array}$} \\
\hline & & & $\mathrm{CR} / 11 / 149$ & Proj. & \\
\hline Total revenue & 46.73 & 64.48 & 76.79 & 79.46 & 95.54 \\
\hline Tax revenue & 41.47 & 56.54 & 67.56 & 69.94 & 83.85 \\
\hline Income and profits & 13.72 & 18.48 & 22.01 & 22.69 & 27.85 \\
\hline Goods and services & 22.89 & 31.69 & 37.69 & 38.85 & 46.26 \\
\hline International trade & 4.08 & 5.26 & 6.53 & 6.73 & 8.08 \\
\hline Other & 0.78 & 1.10 & 1.33 & 1.67 & 1.66 \\
\hline Nontax revenue & 5.26 & 7.94 & 9.23 & 9.51 & 11.69 \\
\hline Total expenditure and net lending & 86.70 & 105.20 & 128.94 & 121.41 & 148.91 \\
\hline Current expenditure & 47.87 & 59.56 & 72.99 & 73.65 & 84.46 \\
\hline Compensation to employees & 23.62 & 29.11 & 36.25 & 36.25 & 41.35 \\
\hline Goods and services & 11.72 & 13.09 & 16.85 & 16.27 & 19.84 \\
\hline Of which: expenditure on ENSSB & $\ldots$ & 0.73 & 0.75 & 0.75 & 1.01 \\
\hline Interest on public debt & 1.36 & 2.67 & 3.31 & 3.31 & 4.63 \\
\hline Transfer payments & 11.17 & 14.69 & 16.58 & 17.82 & 18.63 \\
\hline Of which: fuel subsidy (old stock) & 2.80 & 4.69 & 3.62 & 3.59 & 2.68 \\
\hline New voucher programs & $\ldots$ & $\ldots$ & 0.54 & $\ldots$ & 1.15 \\
\hline Domestic current primary balance & 0.22 & 7.59 & 7.11 & 9.12 & 15.71 \\
\hline Capital expenditure & 34.41 & 43.70 & 44.27 & 43.00 & 51.58 \\
\hline Domestically financed & 11.72 & 20.03 & 18.77 & 20.58 & 24.26 \\
\hline Externally financed & 22.69 & 23.67 & 25.50 & 22.42 & 27.31 \\
\hline Net lending & 4.42 & 1.93 & 11.68 & 4.76 & 12.88 \\
\hline Domestically financed & -0.02 & -0.40 & 0.19 & 0.19 & 0.40 \\
\hline Externally financed loans to public enterprises & 4.44 & 2.33 & 11.48 & 4.56 & 12.48 \\
\hline of which: nonconcessional net lending & 0.00 & 0.00 & 7.84 & 1.46 & 7.62 \\
\hline Unallocated revenue $(+) /$ expenditure (-) $1 /$ & 0.00 & 0.88 & 0.00 & 0.00 & 0.00 \\
\hline Domestic primary balance, before grants, above the line $2 /$ & -11.47 & -11.17 & -11.86 & -11.66 & -8.95 \\
\hline Overall balance, before grants & -39.97 & -39.84 & -52.15 & -41.95 & -53.38 \\
\hline Grants received & 25.30 & 28.34 & 27.91 & 28.82 & 28.11 \\
\hline Project support & 16.18 & 17.11 & 17.40 & 16.51 & 18.31 \\
\hline Investment projects & 7.17 & 7.19 & 7.29 & 7.63 & 8.69 \\
\hline Special programs & 8.64 & 9.92 & 10.11 & 8.88 & 9.62 \\
\hline Direct financing & 0.37 & 0.00 & 0.00 & 0.00 & 0.00 \\
\hline Budget support & 9.12 & 11.24 & 10.52 & 12.31 & 9.80 \\
\hline Overall balance, after grants & -14.67 & -11.50 & -24.24 & -13.13 & -25.26 \\
\hline Net external financing & 13.50 & 13.25 & 22.15 & 10.32 & 22.91 \\
\hline Disbursements & 14.20 & 14.28 & 23.26 & 11.36 & 24.91 \\
\hline Project & 6.51 & 8.19 & 8.11 & 5.91 & 9.00 \\
\hline Nonproject support & 7.69 & 6.09 & 15.16 & 5.45 & 15.91 \\
\hline Loans to public enterprises & 3.89 & 2.33 & 11.48 & 4.56 & 12.35 \\
\hline Budget support & 3.80 & 3.76 & 3.67 & 0.89 & 3.56 \\
\hline Cash amortization & -0.70 & -1.03 & -1.11 & -1.04 & -2.00 \\
\hline Net domestic financing & 0.52 & -1.74 & 2.09 & 2.90 & 2.35 \\
\hline Net privatization & 0.41 & -0.01 & 0.00 & -0.09 & 0.00 \\
\hline \multicolumn{6}{|l|}{ Memorandum items: } \\
\hline Net aid flows & 38.26 & 40.78 & 41.22 & 36.60 & 42.33 \\
\hline Gross aid flows & 39.50 & 42.62 & 43.34 & 38.71 & 45.40 \\
\hline Budget support & 12.92 & 14.99 & 14.19 & 13.19 & 13.36 \\
\hline Nonbudget support & 26.58 & 27.63 & 29.15 & 25.52 & 32.04 \\
\hline Project support & 22.69 & 25.30 & 25.50 & 22.42 & 27.31 \\
\hline Loans to public enterprises & 3.89 & 2.33 & 3.65 & 3.10 & 4.73 \\
\hline External debt service & 1.24 & 1.85 & 2.12 & 2.11 & 3.07 \\
\hline
\end{tabular}

Sources: Mozambican authorities; and IMF staff estimates and projections.

${ }^{1}$ Residual discrepancy betw een identified sources and uses of funds.

${ }^{2}$ Revenue minus noninterest current expenditure minus locally financed capital expenditure and locally financed net lending. 
Table 3. Mozambique: Government Finances, 2009-16

(Percent of GDP)

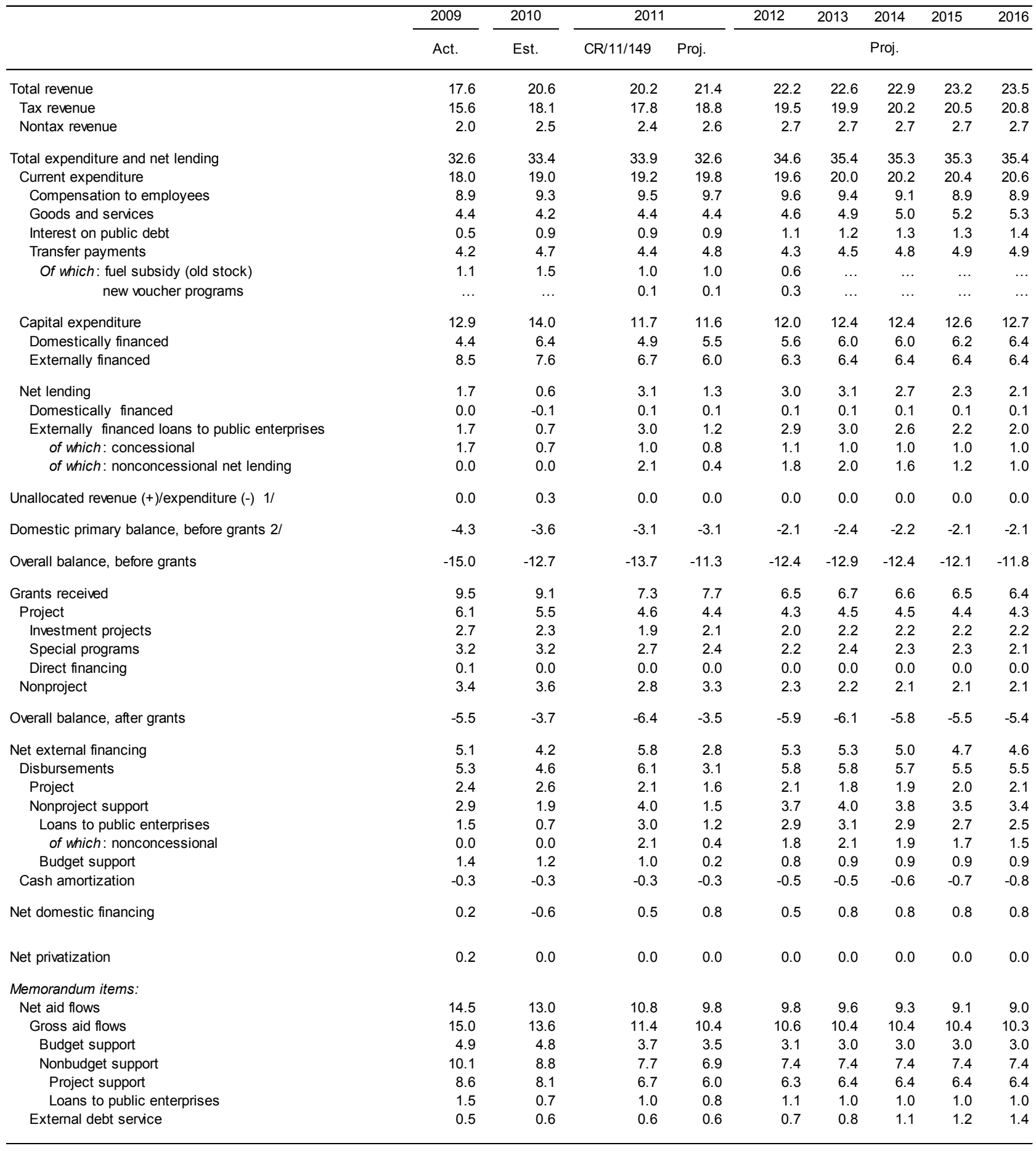

Sources: Mozambican authorities; and IMF staff estimates and projections.

${ }^{1}$ Residual discrepancy betw een identified sources and uses of funds.

${ }^{2}$ Revenue minus noninterest current expenditure minus locally financed capital expenditure and locally financed net lending. 
Table 4. Mozambique: Monetary Survey, Quarterly, 2010-12

(MT Billions, unless otherwise specified)

\begin{tabular}{|c|c|c|c|c|c|c|c|c|c|c|c|c|}
\hline & \multirow{3}{*}{\begin{tabular}{|l}
2010 \\
Q4 \\
Act.
\end{tabular}} & \multicolumn{7}{|c|}{2011} & \multicolumn{4}{|c|}{2012} \\
\hline & & \multicolumn{2}{|c|}{ Q1 } & \multicolumn{2}{|c|}{ Q2 } & \multirow{2}{*}{$\frac{\mathrm{Q} 3}{\mathrm{CR} / 11 / 149}$} & \multicolumn{2}{|c|}{ Q4 } & Q1 & Q2 & Q3 & Q4 \\
\hline & & $\mathrm{CR} / 10 / 375$ & Act. & CR/11/149 & Act. & & CR/11/149 & Proj. & \multicolumn{4}{|c|}{ Proj. } \\
\hline \multicolumn{13}{|l|}{ Bank of Mozambique } \\
\hline $\begin{array}{l}\text { Net foreign assets } \\
\text { (US\$ billions) } \\
\text { Net international reserves } \\
\text { (US\$ billions) }\end{array}$ & $\begin{array}{r}56.9 \\
1.7 \\
62.2 \\
1.9\end{array}$ & $\begin{array}{r}57.7 \\
1.6 \\
62.6 \\
1.7\end{array}$ & $\begin{array}{r}52.8 \\
1.7 \\
57.4 \\
1.9\end{array}$ & $\begin{array}{r}51.7 \\
1.7 \\
56.8 \\
1.8\end{array}$ & $\begin{array}{r}54.8 \\
1.9 \\
59.8 \\
2.1\end{array}$ & $\begin{array}{r}54.4 \\
1.7 \\
59.5 \\
1.9\end{array}$ & $\begin{array}{r}59.5 \\
1.8 \\
64.8 \\
2.0\end{array}$ & $\begin{array}{r}54.2 \\
1.9 \\
58.9 \\
2.0\end{array}$ & $\begin{array}{r}57.4 \\
1.9 \\
62.2 \\
2.1\end{array}$ & $\begin{array}{r}60.7 \\
2.0 \\
65.7 \\
2.2\end{array}$ & $\begin{array}{r}64.2 \\
2.1 \\
69.3 \\
2.2\end{array}$ & $\begin{array}{r}67.7 \\
2.1 \\
72.9 \\
2.3\end{array}$ \\
\hline $\begin{array}{l}\text { Net domestic assets } \\
\text { Credit to government (net) } \\
\text { Credit to banks (net) } \\
\text { Credit to the economy } \\
\text { Other items (net; assets +) }\end{array}$ & $\begin{array}{r}-25.2 \\
-20.6 \\
0.4 \\
0.5 \\
-5.6\end{array}$ & $\begin{array}{r}-30.2 \\
-19.3 \\
-0.5 \\
0.5 \\
-10.8\end{array}$ & $\begin{array}{r}-24.2 \\
-23.7 \\
2.4 \\
0.5 \\
-3.3\end{array}$ & $\begin{array}{r}-21.1 \\
-21.8 \\
2.5 \\
0.5 \\
-2.3\end{array}$ & $\begin{array}{r}-24.2 \\
-26.9 \\
1.6 \\
0.6 \\
0.6\end{array}$ & $\begin{array}{r}-20.2 \\
-20.2 \\
2.4 \\
0.5 \\
-2.8\end{array}$ & $\begin{array}{r}-23.4 \\
-18.5 \\
1.6 \\
0.5 \\
-6.9\end{array}$ & $\begin{array}{r}-18.4 \\
-23.7 \\
4.8 \\
0.6 \\
-0.1\end{array}$ & $\begin{array}{r}-24.0 \\
-19.2 \\
2.0 \\
0.6 \\
-7.5\end{array}$ & $\begin{array}{r}-24.2 \\
-24.6 \\
2.8 \\
0.6 \\
-3.0\end{array}$ & $\begin{array}{r}-26.6 \\
-22.7 \\
4.0 \\
0.6 \\
-8.5\end{array}$ & $\begin{array}{r}-25.4 \\
-19.7 \\
5.7 \\
0.6 \\
-12.0\end{array}$ \\
\hline $\begin{array}{l}\text { Reserve money } \\
\text { Currency in circulation } \\
\text { Currency outside banks } \\
\text { Currency in Banks (Cash in Vault) } \\
\text { Bank deposits in BM }\end{array}$ & $\begin{array}{r}31.6 \\
20.4 \\
17.4 \\
3.0 \\
11.2\end{array}$ & $\begin{array}{r}27.5 \\
16.1 \\
14.5 \\
1.6 \\
11.4\end{array}$ & $\begin{array}{r}28.6 \\
17.1 \\
14.7 \\
2.4 \\
11.5\end{array}$ & $\begin{array}{r}30.6 \\
19.2 \\
17.0 \\
2.2 \\
11.4\end{array}$ & $\begin{array}{r}30.6 \\
19.1 \\
16.5 \\
2.6 \\
11.5\end{array}$ & $\begin{array}{r}34.2 \\
22.5 \\
20.6 \\
1.9 \\
11.7\end{array}$ & $\begin{array}{l}36.2 \\
24.1 \\
24.6 \\
-0.4 \\
12.0\end{array}$ & $\begin{array}{l}35.8 \\
23.6 \\
11.3 \\
12.3 \\
12.1\end{array}$ & $\begin{array}{l}33.4 \\
21.2 \\
10.8 \\
10.4 \\
12.2\end{array}$ & $\begin{array}{r}36.6 \\
23.3 \\
5.3 \\
18.0 \\
13.3\end{array}$ & $\begin{array}{r}37.6 \\
23.9 \\
7.2 \\
16.7 \\
13.8\end{array}$ & $\begin{array}{l}42.3 \\
27.9 \\
13.3 \\
14.6 \\
14.4\end{array}$ \\
\hline $\begin{array}{l}\text { Net foreign assets } \\
\quad \text { (in millions of U.S. dollars) }\end{array}$ & $\begin{array}{r}22.8 \\
0.7\end{array}$ & $\begin{array}{l}9.0 \\
0.2\end{array}$ & $\begin{array}{r}24.5 \\
0.8\end{array}$ & $\begin{array}{r}16.1 \\
0.5\end{array}$ & $\begin{array}{r}17.9 \\
0.6\end{array}$ & $\begin{array}{r}11.7 \\
0.4\end{array}$ & $\begin{array}{r}15.6 \\
0.5\end{array}$ & $\begin{array}{r}16.8 \\
0.6\end{array}$ & $\begin{array}{r}24.0 \\
0.8\end{array}$ & $\begin{array}{r}24.7 \\
0.8\end{array}$ & $\begin{array}{r}26.4 \\
0.8\end{array}$ & $\begin{array}{r}26.6 \\
0.8\end{array}$ \\
\hline $\begin{array}{l}\text { Net domestic assets } \\
\text { Banks' reserves } \\
\text { Credit to BM (net) } \\
\text { Credit to government (net) } \\
\text { Credit to the economy } \\
\text { Other items (net; assets +) }\end{array}$ & $\begin{array}{r}90.6 \\
14.3 \\
-0.3 \\
7.9 \\
90.6 \\
-21.9\end{array}$ & $\begin{array}{r}110.4 \\
13.1 \\
0.5 \\
10.2 \\
99.2 \\
-12.6\end{array}$ & $\begin{array}{r}89.4 \\
13.9 \\
-2.0 \\
8.9 \\
91.9 \\
-23.3\end{array}$ & $\begin{array}{r}110.9 \\
13.6 \\
-2.5 \\
8.3 \\
104.1 \\
-12.6\end{array}$ & $\begin{array}{r}94.4 \\
14.3 \\
-1.4 \\
12.4 \\
93.4 \\
-24.3\end{array}$ & $\begin{array}{r}118.4 \\
13.6 \\
-2.4 \\
7.3 \\
108.6 \\
-8.6\end{array}$ & $\begin{array}{r}117.6 \\
11.6 \\
-1.6 \\
7.9 \\
108.3 \\
-8.6\end{array}$ & $\begin{array}{r}118.7 \\
24.5 \\
-4.8 \\
14.2 \\
106.3 \\
-21.4\end{array}$ & $\begin{array}{r}111.7 \\
22.6 \\
-2.0 \\
12.9 \\
106.6 \\
-28.4\end{array}$ & $\begin{array}{r}124.3 \\
31.3 \\
-2.8 \\
13.0 \\
110.3 \\
-27.5\end{array}$ & $\begin{array}{r}127.5 \\
30.5 \\
-4.0 \\
12.9 \\
120.3 \\
-32.1\end{array}$ & $\begin{array}{r}134.7 \\
29.0 \\
-5.7 \\
12.8 \\
129.6 \\
-31.0\end{array}$ \\
\hline $\begin{array}{l}\text { Deposits } \\
\text { Demand and savings deposits } \\
\text { Time deposits }\end{array}$ & $\begin{array}{r}113.3 \\
71.1 \\
42.3\end{array}$ & $\begin{array}{r}119.4 \\
72.2 \\
47.2\end{array}$ & $\begin{array}{r}113.8 \\
72.8 \\
41.0\end{array}$ & $\begin{array}{r}127.0 \\
79.9 \\
47.0\end{array}$ & $\begin{array}{r}112.3 \\
71.8 \\
40.4\end{array}$ & $\begin{array}{r}130.1 \\
81.9 \\
48.2\end{array}$ & $\begin{array}{r}133.2 \\
82.1 \\
51.1\end{array}$ & $\begin{array}{r}135.5 \\
89.6 \\
45.9\end{array}$ & $\begin{array}{r}135.7 \\
88.3 \\
47.4\end{array}$ & $\begin{array}{r}149.0 \\
99.1 \\
50.0\end{array}$ & $\begin{array}{r}154.0 \\
102.8 \\
51.2\end{array}$ & $\begin{array}{r}161.3 \\
106.4 \\
54.9\end{array}$ \\
\hline \multicolumn{13}{|l|}{ Monetary Survey } \\
\hline $\begin{array}{l}\text { Net foreign assets } \\
\text { (US\$ billions) }\end{array}$ & $\begin{array}{r}79.6 \\
2.4\end{array}$ & $\begin{array}{r}66.7 \\
1.8\end{array}$ & $\begin{array}{r}77.3 \\
2.5\end{array}$ & $\begin{array}{r}67.8 \\
2.2\end{array}$ & $\begin{array}{r}72.7 \\
2.5\end{array}$ & $\begin{array}{r}66.1 \\
2.1\end{array}$ & $\begin{array}{r}75.2 \\
2.3\end{array}$ & $\begin{array}{r}71.0 \\
2.4\end{array}$ & $\begin{array}{r}81.4 \\
2.7\end{array}$ & $\begin{array}{r}85.5 \\
2.8\end{array}$ & $\begin{array}{r}90.7 \\
2.9\end{array}$ & $\begin{array}{r}94.3 \\
2.9\end{array}$ \\
\hline $\begin{array}{l}\text { Net domestic assets } \\
\text { Domestic credit } \\
\text { Credit to government (net) } \\
\text { Credit to the economy } \\
\text { Cred. economy in foreign currency } \\
\text { Other items (net; assets +) }\end{array}$ & $\begin{array}{r}51.8 \\
78.3 \\
-12.7 \\
91.1 \\
27.2 \\
-26.5\end{array}$ & $\begin{array}{r}67.2 \\
90.6 \\
-9.1 \\
99.7 \\
35.9 \\
-23.4\end{array}$ & $\begin{array}{r}52.0 \\
77.5 \\
-14.9 \\
92.4 \\
25.3 \\
-25.5\end{array}$ & $\begin{array}{r}76.1 \\
91.1 \\
-13.5 \\
104.6 \\
32.0 \\
-14.9\end{array}$ & $\begin{array}{r}57.1 \\
79.4 \\
-14.6 \\
94.0 \\
23.8 \\
-22.3\end{array}$ & $\begin{array}{r}84.6 \\
96.1 \\
-13.0 \\
109.1 \\
33.6 \\
-11.5\end{array}$ & $\begin{array}{r}82.6 \\
98.1 \\
-10.7 \\
108.8 \\
31.9 \\
-15.5\end{array}$ & $\begin{array}{r}75.9 \\
97.3 \\
-9.5 \\
106.9 \\
24.6 \\
-21.5\end{array}$ & $\begin{array}{r}65.1 \\
100.9 \\
-6.3 \\
107.3 \\
24.5 \\
-35.9\end{array}$ & $\begin{array}{r}68.8 \\
99.3 \\
-11.6 \\
110.9 \\
24.3 \\
-30.4\end{array}$ & $\begin{array}{r}70.5 \\
111.0 \\
-9.9 \\
120.9 \\
25.6 \\
-40.5\end{array}$ & $\begin{array}{r}80.3 \\
123.3 \\
-6.9 \\
130.2 \\
29.4 \\
-43.0\end{array}$ \\
\hline \multicolumn{13}{|l|}{ Memorandum Items } \\
\hline $\begin{array}{l}\text { Avg daily reserve money in } 3 \mathrm{rd} \text { month of quarter } \\
12 \text {-month percent change } \\
\text { Avg daily currency in 3rd month of quarter } \\
\text { 12-month percent change }\end{array}$ & $\begin{array}{l}31.8 \\
35.0 \\
20.4 \\
30.1\end{array}$ & $\begin{array}{l}27.4 \\
19.9 \\
15.9 \\
10.9\end{array}$ & $\begin{array}{l}29.0 \\
27.0 \\
17.3 \\
21.0\end{array}$ & $\begin{array}{l}29.8 \\
17.4 \\
18.4 \\
14.6\end{array}$ & $\begin{array}{l}30.7 \\
21.0 \\
18.7 \\
16.4\end{array}$ & $\begin{array}{l}33.7 \\
16.6 \\
21.9 \\
22.6\end{array}$ & $\begin{array}{l}36.4 \\
14.3 \\
24.1 \\
18.1\end{array}$ & $\begin{array}{l}36.1 \\
13.2 \\
23.6 \\
15.7\end{array}$ & $\begin{array}{l}33.8 \\
16.6 \\
21.5 \\
24.1\end{array}$ & $\begin{array}{l}36.7 \\
19.5 \\
22.8 \\
21.9\end{array}$ & $\begin{array}{l}37.1 \\
18.0 \\
23.2 \\
14.4\end{array}$ & $\begin{array}{l}42.7 \\
18.3 \\
27.9 \\
18.2\end{array}$ \\
\hline $\begin{array}{l}\text { NCG stock (prog def.) } 1 \\
\text { NCG flow (prog def.) cum from end-year } 1\end{array}$ & $\begin{array}{r}-16.3 \\
-1.7\end{array}$ & $\begin{array}{r}-12.5 \\
1.1\end{array}$ & $\begin{array}{r}-18.6 \\
-2.3\end{array}$ & $\begin{array}{r}-17.2 \\
-0.9\end{array}$ & $\begin{array}{r}-18.4 \\
-2.1\end{array}$ & $\begin{array}{r}-16.7 \\
-0.4\end{array}$ & $\begin{array}{r}-14.3 \\
2.1\end{array}$ & $\begin{array}{r}-13.5 \\
2.9\end{array}$ & $\begin{array}{r}-10.7 \\
2.8\end{array}$ & $\begin{array}{r}-16.1 \\
-2.6\end{array}$ & $\begin{array}{r}-14.2 \\
-0.7\end{array}$ & $\begin{array}{r}-11.1 \\
2.4\end{array}$ \\
\hline $\begin{array}{l}\text { 12-month percent change } \\
\text { Reserve money } \\
\text { M2 } \\
\text { M3 } \\
\text { Credit to the economy }\end{array}$ & $\begin{array}{l}29.2 \\
17.6 \\
22.8 \\
27.5\end{array}$ & $\begin{array}{l}19.9 \\
27.7 \\
23.6 \\
33.7\end{array}$ & $\begin{array}{l}24.6 \\
18.2 \\
19.4 \\
24.0\end{array}$ & $\begin{array}{l}17.4 \\
18.7 \\
21.5 \\
26.2\end{array}$ & $\begin{array}{r}17.5 \\
18.8 \\
9.5 \\
13.5\end{array}$ & $\begin{array}{l}16.6 \\
19.7 \\
17.8 \\
19.6\end{array}$ & $\begin{array}{l}14.3 \\
20.4 \\
20.0 \\
19.5\end{array}$ & $\begin{array}{l}13.2 \\
17.2 \\
11.7 \\
17.4\end{array}$ & $\begin{array}{l}16.6 \\
18.3 \\
13.2 \\
16.1\end{array}$ & $\begin{array}{l}19.5 \\
18.5 \\
18.9 \\
18.0\end{array}$ & $\begin{array}{l}18.0 \\
18.8 \\
18.0 \\
26.4\end{array}$ & $\begin{array}{l}18.3 \\
19.5 \\
18.9 \\
21.8\end{array}$ \\
\hline $\begin{array}{l}\text { Money multiplier (M2/reserve money) } \\
\text { Velocity (GDP/M2) }\end{array}$ & $\begin{array}{l}2.70 \\
3.67\end{array}$ & $\begin{array}{r}3.30 \\
\ldots\end{array}$ & $\begin{array}{r}2.94 \\
\ldots\end{array}$ & 2.96 & $\begin{array}{r}2.96 \\
\ldots\end{array}$ & 2.78 & $\begin{array}{l}2.84 \\
3.70\end{array}$ & $\begin{array}{l}2.79 \\
3.72\end{array}$ & $\begin{array}{l}2.98 \\
4.33\end{array}$ & $\begin{array}{l}2.93 \\
4.01\end{array}$ & $\begin{array}{l}3.01 \\
3.81\end{array}$ & $\begin{array}{l}2.82 \\
3.60\end{array}$ \\
\hline $\begin{array}{l}\text { Nominal GDP } \\
\text { Nominal GDP growth }\end{array}$ & $\begin{array}{r}313 \\
17.5\end{array}$ & $\begin{array}{l}\cdots \\
\cdots\end{array}$ & $\begin{array}{l}\cdots \\
\ldots\end{array}$ & $\begin{array}{l}\cdots \\
\cdots\end{array}$ & $\begin{array}{l}\cdots \\
\ldots\end{array}$ & $\begin{array}{l}\cdots \\
\cdots\end{array}$ & $\begin{array}{r}380 \\
17.4\end{array}$ & $\begin{array}{r}372 \\
18.9\end{array}$ & $\begin{array}{l}\cdots \\
\ldots\end{array}$ & $\begin{array}{l}\cdots \\
\ldots\end{array}$ & $\begin{array}{l}\cdots \\
\ldots\end{array}$ & $\begin{array}{r}430 \\
15.6\end{array}$ \\
\hline
\end{tabular}

Sources: Bank of Mozambique; and IMF staff estimates and projections.

${ }^{1}$ As defined in the TMU (excluding the non concessional Portuguese credit line). 
Table 5. Mozambique: Balance of Payments, 2009-16

(Millions of U.S. dollars, unless otherwise specified)

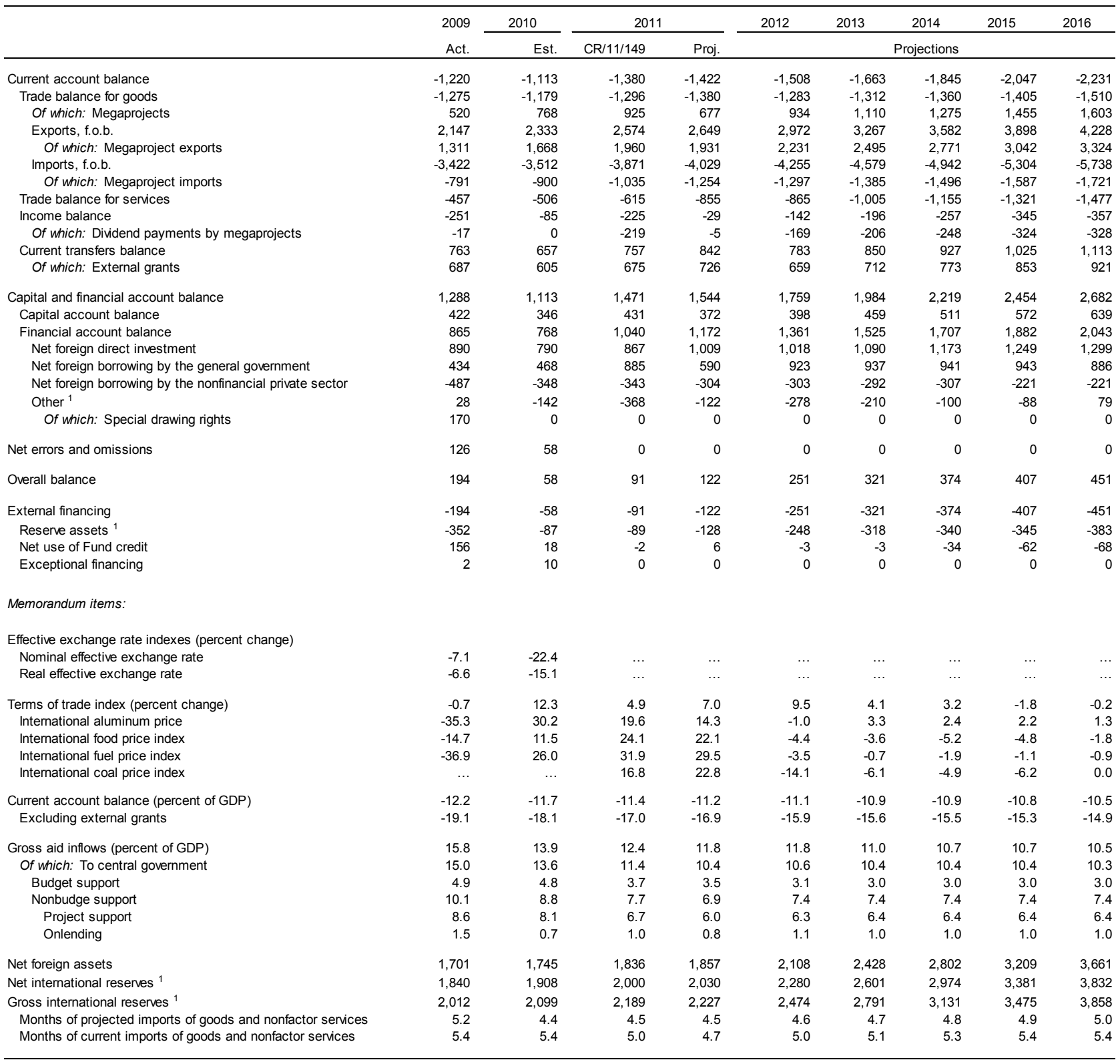

Sources: Data from Government of Mozambique and projections by IMF staff.

${ }^{1}$ Accounts for disbursement of an SDR allocation of SDR 108.8 million in 2009 Q3 above the line under other investment liabilities of the monetary authorities, and below the line

as an increase in reserve assets. 
Table 6. Mozambique: Financial Soundness Indicators for Banking Sector, 2001-11

\begin{tabular}{|c|c|c|c|c|c|c|c|c|c|c|c|c|c|c|c|c|c|c|}
\hline & 2001 & 2002 & 2003 & 2004 & 2005 & 2006 & 2007 & 2008 & $\begin{array}{l}\text { Mar-09 } \\
\end{array}$ & Jun-09 & Sep-09 & Dec-09 & Mar-10 & Jun-10 & Sep-10 & Dec-10 & Mar-11 & Jun-11 \\
\hline \multicolumn{19}{|l|}{ Capital adequacy } \\
\hline Regulatory capital to risk-weighted assets & 5.5 & 14.0 & 16.5 & 18.0 & 13.4 & 12.5 & 14.2 & 13.9 & 16.9 & 18.1 & 16.6 & 15.1 & 14.8 & 15.2 & 15.3 & 14.4 & 15.3 & 18.7 \\
\hline Regulatory Tier I capital to risk-weighted assets & 6.0 & 12.0 & 14.7 & 16.0 & 13.6 & 10.7 & 12.1 & 12.4 & 14.9 & 16.2 & 14.3 & 13.0 & 12.2 & 13.3 & 13.7 & 13.7 & 13.8 & 16.8 \\
\hline Capital (net worth) to assets & 8.2 & 9.4 & 7.4 & 7.4 & 6.6 & 6.3 & 7.2 & 7.5 & 8.9 & 9.3 & 8.4 & 7.7 & 7.6 & 8.0 & 8.0 & 8.0 & 8.5 & \\
\hline \multicolumn{19}{|l|}{ Asset composition and quality } \\
\hline Foreign exchange loans to total loans & 64.7 & 69.9 & 60.8 & 62.0 & 51.4 & 33.2 & 28.5 & 32.8 & 35.2 & 33.1 & 36.2 & 32.4 & 33.2 & 34.4 & 32.7 & 29.5 & 27.2 & 25.0 \\
\hline Nonperforming loans to gross loans $1 /$ & 23.4 & 22.0 & 13.8 & 5.9 & 3.5 & 3.1 & 2.6 & 1.9 & 2.0 & 2.2 & 2.0 & $\begin{array}{l}1.8 \\
59\end{array}$ & 2.1 & 2.1 & 2.0 & 1.9 & 2.3 & 2.3 \\
\hline Nonperforming loans net of provisions to capital $1 /$ & 11.0 & 9.4 & 8.8 & 3.8 & 1.9 & 3.6 & 0.5 & 2.5 & 3.3 & 5.5 & 5.8 & 5.9 & 5.9 & 7.9 & 7.0 & 5.6 & 6.1 & 5.9 \\
\hline \multicolumn{19}{|l|}{ Earnings and profitability } \\
\hline Return on assets & 0.1 & 1.6 & 1.4 & 1.5 & 1.9 & 4.0 & 3.8 & 3.5 & 4.2 & 3.6 & 3.1 & 3.0 & 4.3 & 3.4 & 3.0 & 2.6 & 2.9 & 3.0 \\
\hline Return on equity & 3.5 & 22.1 & 18.6 & 20.6 & 26.9 & 60.8 & 50.7 & 44.7 & 53.4 & 44.3 & 37.0 & 36.6 & 53.1 & 42.7 & 37.8 & 32.9 & 36.0 & 34.6 \\
\hline Interest margin to gross income & 10.2 & 61.4 & 62.1 & 65.8 & 63.6 & 67.4 & 70.2 & 58.8 & 58.3 & 57.6 & 57.4 & 55.7 & 47.9 & 53.7 & 56.7 & 59.4 & 64.4 & 66.8 \\
\hline Noninterest expenses to gross income & 16.9 & 67.0 & 81.9 & 81.6 & 75.2 & 60.2 & 60.8 & 58.7 & 55.4 & 59.1 & 59.0 & 58.4 & 51.1 & 56.5 & 57.7 & 59.7 & 61.4 & 58.2 \\
\hline Personnel expenses to noninterest expenses & 51.7 & 44.7 & 42.4 & 43.1 & 43.5 & 42.6 & 46.3 & 45.1 & 49.2 & 46.6 & 46.4 & 45.9 & 45.9 & 45.8 & 45.2 & 45.5 & 46.7 & 47.1 \\
\hline Trading and fee income to gross income & 33.1 & 39.7 & 37.9 & 34.2 & 36.4 & 32.6 & 29.5 & 40.5 & 41.7 & 40.8 & 41.5 & 44.3 & 52.1 & 43.2 & 39.0 & 23.8 & 18.3 & 16.0 \\
\hline Spread between reference loan and deposit rates ( 90 days, local currency) & 14.0 & 19.0 & 17.4 & 14.9 & 13.8 & 14.6 & 11.1 & 10.7 & 10.6 & 11.3 & 11.0 & 11.1 & 11.7 & 12.5 & $\ldots$ & $\ldots$ & 9.6 & \\
\hline \multicolumn{19}{|l|}{ Funding and liquidity } \\
\hline Liquid assets to total assets 21 & 34.6 & 53.9 & 45.2 & 38.3 & 31.1 & 33.9 & 36.0 & 36.2 & 34.8 & 32.2 & 30.3 & 27.9 & 25.9 & 22.5 & 21.5 & 22.4 & 22.1 & $\begin{array}{r}23.2 \\
126.9\end{array}$ \\
\hline Customer deposits to total (non-interbank) loans & 217.0 & 240.0 & 193.6 & 205.0 & 177.6 & 169.5 & 184.9 & 165.7 & 158.6 & 155.3 & 147.9 & 138.2 & 131.5 & 126.6 & 127.5 & 131.2 & 129.6 & 126.9 \\
\hline
\end{tabular}

1/ Nonperforming loans are defined according to Mozambican accounting standards (they include only part of the past-due loans).
2/ Includes deposits at parent banks. 


\title{
LETTER OF INTENT-REPUBLIC OF MOZAMBIQUE
}

November 14, 2011

\author{
Ms. Christine Lagarde \\ Managing Director \\ International Monetary Fund \\ Washington, D.C. 20431 \\ U.S.A.
}

\section{Dear Ms. Lagarde:}

The Government of Mozambique requests the completion of the third review under the Policy Support Instrument (PSI). In support of this request, we are transmitting the attached Memorandum of Economic and Financial Policies (MEFP), which reviews implementation of our economic program under the PSI and sets out the Government's objectives and policies over the short and medium term.

The Government's economic program aims to maintain macroeconomic stability, promote more inclusive growth through public investment and the promotion of productive employment, and reduce poverty. The program aims to support the implementation of the new Poverty Reduction Strategy Paper (PARP) for 2011-14, which the Government formally adopted on May 3, 2011.

The Government is of the view that the policies outlined in the MEFP are adequate to achieve the objectives of the PSI-supported program. We stand ready to take any additional measures necessary to achieve our policy objectives. The Government will consult with the IMF - at its own initiative or whenever the Managing Director requests such a consultation-should revisions be contemplated regarding the policies contained in the attached MEFP. The Government will provide the IMF with such information as the IMF may request to be able to assess the progress made in implementing the economic and financial policies and achieving the objectives of the program.

Sincerely yours,

$\begin{array}{cc}\text { /s/ } & / \mathrm{s} / \\ \text { Manuel Chang } & \text { Ernesto Gouveia Gove } \\ \text { Minister of Finance } & \text { Governor }\end{array}$

Attachments: Memorandum of Economic and Financial Policies

Technical Memorandum of Understanding 


\section{Attachment 1: Memorandum of Economic and Financial Policies}

November 14, 2011

1. This updated MEFP (i) describes recent developments and performance under the Government's economic program under the three-year Policy Support Instrument (PSI) through October 2011 and (ii) elaborates on economic and structural policy intentions through 2012. It builds on the MEFPs underlying the initial PSI request dated May 28, 2010 and those for the first and second reviews from November 8, 2010, and May 20, 2011 respectively.

\section{RECENT ECONOMIC DEVELOPMENTS AND PERFORMANCE UNDER THE PROGRAM}

2. Mozambique remains resilient to the renewed global turbulence. Our economy continues to weather the global financial crisis remarkably well. Economic activity in the first half of the year is estimated at 7.4 percent, buttressed by good harvests and a robust performance in the service and transport and communication sectors. Twelve-month inflation declined sharply from its peak of 16.6 percent at end-2010, standing at 7.8 percent at end-September 2011. Inflation expectations have fallen as well, since core inflation (excluding food and fuel prices) has been declining steadily to 7.7 percent at end-September 2011. This reflects the determined monetary and fiscal policy tightening, favorable developments of international prices, a good harvest, and a stronger metical. The increase in the import bill for fuel products and megaproject investments was partly offset by an acceleration in both megaproject and traditional exports, resulting in a current account deficit of 11.2 percent of GDP, broadly in line with our initial projections. This, together with robust capital inflows, contributed to a stronger-than-projected international reserves position.

\section{Mozambique's program performance remains strong:}

- All end-June 2010 quantitative assessment criteria (AC) were met, except for reserve money (RM), which was marginally exceeded. Nonetheless, the sharp tightening of monetary policy resulted in negative RM growth in the first half of 2011. The BM kept disinflation policies on course by comfortably meeting the end-September indicative target on RM. It also observed all program targets on net international reserves (NIR) through end-September.

- The Government's fiscal policy stance has supported the disinflation effort as well, with net credit to the government (NCG) and government revenue exceeding the respective program targets for end-June by a large margin. This was achieved on account of a determined revenue mobilization effort and a slow budget execution, especially of the externallyfinanced component. However, the latter resulted in us missing the indicative targets on priority spending for end-March and end-June 2011. No new non-concessional borrowing (NCB) has been signed since April 2011.

- As to the end-July structural benchmarks, we launched the civil service and wage payment database on time and produced a first quarterly report. In addition, the Council of Ministers adopted the anti-corruption package on July 26, and the legislation has formally been submitted in full to Parliament on November 1. 
4. The Government took important steps to implement Mozambique's new fouryear PARP. It finalized the PARP matrix of structural measures in August 2011, in close consultation with key stakeholders. The recent approval of the Agricultural Reform Strategy (PEDSA) will help delineate a detailed an action plan to achieve the key objectives under the PARP pillar on increasing production and productivity in agriculture and fisheries. The Council of Ministers approved in September 2011 a number of programs that would support the National Basic Social Security Strategy (ENSSB), involving a wide range of programs with special focus on direct social protection transfers and productive public works programs in urban and rural areas.

\section{Macroeconomic Policies}

\section{A. Economic Objectives}

5. Despite weakening global economic prospects, the Government continues to foresee a positive macroeconomic outlook for Mozambique for 2011 and beyond. Economic growth could reach 71/4 percent in 2011 and approach 8 percent over the medium term. On the back of our strong efforts to arrest inflation expectations, we expect headline inflation to remain in single digits through end-2011, subject to international food and fuel price developments, and to our inflation objective of below 6 percent over the medium term. The external current account deficit (after grants) is set to stabilize at around 10 to 11 percent of GDP during the next few years, while the reserves coverage of imports should approach 5 months due to increasing private capital inflows, exports from new mining megaprojects, and continued donor support.

6. The difficult global environment has increased risks to the outlook. As was the case in 2008-09, the global crisis may affect Mozambique through two main contagion channels: a decline in commodity prices for the country's minerals and reduced access to international finance by the private sector. In addition, economic difficulties in our partner countries may lead to less predictable aid and other financial inflows and may have repercussions on our financial system. Although current indications point to no immediate pressures in these areas, we have stepped up our vigilance and stand ready to adjust our policies, in consultation with IMF staff.

\section{B. Macroeconomic Policy Mix}

7. Policies for the remainder of this year and for 2012 need to balance the need to keep inflation expectations in check with supporting our investment and social development goals. The Bank of Mozambique (BM) will ease monetary policy cautiously, consistent with the annual inflation objective, the significant disinflation to date, and the need to enable more private sector credit growth. Fiscal policy will be supportive to the BM's efforts, with a further reduction of the domestic primary deficit and limited recourse to domestic financing, which should help contain domestic demand and avoid a crowding out of the private sector.

8. Over the medium term, consistent with the PARP, we will adhere to a policy stance that supports inclusive growth while preserving macroeconomic stability and debt 
sustainability. Monetary policy will continue to be geared toward achieving low levels of inflation, complemented by efforts to promote financial deepening and develop domestic debt markets. Fiscal policy will seek to step up investment spending to close the infrastructure gap and support our social and human development objectives, allowing for a gradual expansion of social safety nets to address chronic poverty and foster social cohesion. To this end, we intend to create additional fiscal space mainly through a continued increase in the revenue-to-GDP ratio and selective nonconcessional external borrowing (NCB), the latter primarily for capital projects with an expected high economic return. This policy stance will be consistent with maintaining macroeconomic stability and debt sustainability.

\section{Monetary and Exchange Rate Policies}

9. The authorities are determined to maintain their disinflation monetary policy stance. Our objective is to contain end-of-period inflation to $8 \frac{1}{2}$ percent in 2011 and below 6 percent in 2012. This will continue to be achieved by keeping monetary expansion, in particular RM growth, under close control. In 2011, we aim to contain RM growth to about 13 percent. Going forward, in tandem with our progress in combating inflation, RM growth will accelerate and expand slightly above nominal GDP growth to support financial deepening.

10. The authorities intend to further strengthen the BM's operational framework.

This will allow the BM to improve its liquidity forecasting and more effectively steer monetary conditions. Specifically, this entails:

- Monitoring of government accounts. The implementation of the MoU signed on March 25, 2011 on the exchange of information between the BM and the Ministry of Finance (MoF) will be accelerated. Among other things, by end-November 2011, the MoF and the BM will work on changing existing rules to (i) avoid unexpected Government flows near market close to provide commercial banks with sufficient time to fine-tune their daily liquidity conditions and enhance the effectiveness of BM monetary interventions to drain or add liquidity; and (ii) cancel authorizations for public institutions in e-SISTAFE if they do not use them within one week. The MoF is already providing the BM with information on the nature of government expenses and revenues in foreign currency, and we will now focus on technical solutions to provide similar information in domestic currency. The MoF will also provide the $\mathrm{BM}$ with monthly historical data on government expenses and revenues so as to allow the $\mathrm{BM}$ to better capture seasonal patterns.

- Development of the domestic repo market to help improve money market management and the liquidity of government securities. By end-July 2012, the BM will (i) modify the Meticalnet Interbank Money Market (MMI) auction modules to accept not only Treasury bills (BT) issued by the BM but also government bonds (OT) issued by the stock exchange as collateral for BM repo transactions; (ii) allow repeated use of the same securities for repos; and (iii) make all BT equally eligible to the BM repo transactions. In addition, by end-March 2012, based on an impact study, the authorities will decide on measures to equalize the tax treatment between BT and OT and between collateralized and uncollateralized interbank market operations. By end-September 2012, we will submit to Parliament an amendment to the Corporate Income Tax Law that will reflect this equalization, to take effect in 2013 
(structural benchmark). This will eliminate the current 10 percent tax bias against BT and the current tax incentive to conduct uncollateralized operations (taxes on collateralized operations are to be paid each month, while uncollateralized transactions are taxed only in April of the subsequent year in the context of banks' annual tax payments based on their balance sheet).

11. The BM intends to move toward an inflation-targeting framework over the next few years. Supported by Fund technical assistance (TA), important progress is being made in improving data collection and analysis, developing forecasting techniques, and setting the stage for enhanced communications to transparently and efficiently explain the BM's policy intentions. With regard to the latter, the BM will publish, by end-May 2012, its first quarterly monetary policy report, which will cover a broad range of issues, such as the international policy environment, the domestic economic activity and outlook, and an analysis of policy developments (structural benchmark). In light of the progress made in modeling macroeconomic and liquidity developments, including with respect to forecasting and managing currency in circulation, we will reduce the currency adjuster under the program's reserve money target to MT 250 million for all 2012 RM program targets and to eliminate it altogether beginning with the end-March 2013 target.

12. Mozambique's flexible exchange rate regime remains appropriate. The BM will continue to allow the exchange rate to adjust freely to evolving patterns of trade and financial flows while further strengthening Mozambique's international reserves, which are projected to approach 5 months of projected imports over the medium term. The BM will continue to closely monitor developments in the real effective exchange rate vis-à-vis a broad basket of currencies.

13. The BM will ensure that Mozambique remains committed to its obligations under Article VIII, sections 2, 3, and 4 of the Fund's Articles of Agreement. The BM will continue to monitor the implementation of the new foreign exchange regulations, its implementation norms, as well as the functioning of the foreign exchange market, with a view to avoiding practices that could turn out to be inconsistent with Article VIII principles. We will keep IMF staff informed of any developments that could potentially run against those principles.

\section{Fiscal Policy}

14. Fiscal policy will help the Government in its quest for more inclusive growth, but in the short run be geared toward supporting BM's disinflationary effort.

- We will maintain our revenue effort and prudent budget implementation in 2011, keeping the domestic primary deficit, at about 3 percent of GDP, broadly unchanged relative to prior understandings. By contrast, we expect a much slower execution of externally-financed spending, resulting in a projected sharply lower overall fiscal deficit than previously planned. In addition, a shift in budget support between fiscal years agreed upon with donors necessitates a slight increase in the NCG to 0.8 percent of GDP.

- The fiscal policy stance in 2012 will remain supportive of disinflation while boosting the authorities' investment and social development plans. While the domestic primary deficit and 
NCG will be limited to about 2 percent and $1 / 2$ percent of GDP, respectively, the overall deficit will rise to 5.8 percent of GDP to benefit from the space available under the program for

NCB to help finance a surge in capital spending and on-lending for infrastructure investment.

\section{The implementation of the $\mathbf{2 0 1 2}$ budget law will be subject to the revenue} contingency under the organic budget law (SISTAFE 2002). This legal framework limits budget execution to cautionary ceilings as long as revenue collections remain uncertain. To this end, and in accordance with the legal provisions of the 2012 budget law, the Government will take the following steps by end-January 2012: (i) the Council of Ministers will approve the decree on the provisions regarding budget execution (Decreto de Delegação de Competências sobre a Execução do Orçamento); and (ii) the Minister of Finance will issue an interministerial regulation (Circular Ministerial) providing guidance for line ministries for budget execution and contingencies. Accordingly, the following contingency ceilings will apply: (i) 90 percent for goods and services and other current expenditures; (ii) 85 percent for civil service wages and transfers; and (iii) 90 percent for domestically-financed capital spending.

\section{We will support implementation of the PARP by expanding social protection} while moving toward eliminating the costly fuel subsidy.

- Social protection schemes. The September 2011 approval by the Council of Ministers allows the Ministry for Women and Social Action (MMAS) to embark on the implementation of a revamped system of direct social protection transfers and the launch of productive public works programs in urban and rural areas, with an initial targeted number of beneficiaries of 309,000 in 2012 as a result of a real increase in budget allocations of 25 percent relative to 2011. We will seek to gradually expand our own budgetary and donor resources for social protection to enhance coverage to 815,000 beneficiaries by 2014 . Supported by TA from our partners, we will strive to strengthen our institutional capacity to implement, monitor, and assess the schemes. MMAS will revise targeting and beneficiary selection mechanisms, payment procedures, and monitoring and evaluation systems (e.g., single registry of beneficiaries), building on the on-going evaluation of the current transfer system.

- Fuel subsidy phase-out. The Government made good progress in phasing out the fuel subsidy through a series of price increases. It raised the diesel and gasoline prices by 10 percent in April and 8 percent in July, leaving only diesel pump prices subsidized. Barring any unforeseen international price surges, we expect to be able to end the subsidization by early 2012, which would allow us to return to the unrestricted application of the price-setting formula. Consistent with the agreement reached in December 2010, the Government paid off the entire debt to fuel importers incurred in 2010 (MT 3.6 billion). We will compensate importers for incurred 2011 losses. For this purpose, we have included an amount under the 2012 budget. Our budget documents will continue to show the full costs of any outlays for fuel products, in line with best fiscal transparency principles.

- Vouchers and food subsidies. The 2012 budget provides additional resources to continue the existing subsidies on wheat for bread and to introduce urban transport vouchers in 2012. A tender for the voucher system's management has been launched. Given the importance of an efficient urban transport system for our citizens, especially the poor, we have created a fund 
to undertake investment in the sector, such as the purchase of buses. The fund, financed by an earmarked share of the fuel tax, transport receipts, and the sale of idle Government assets, is fully integrated in the central Government budget.

17. We aim to further increase spending for priority sectors. Such spending will, for the time being, continue to be defined under the 2006-10 PARPA program categories, comprising outlays in education, health, HIV/AIDS, infrastructure development, agriculture, rural development, governance, and the judicial system. We envisage to increase such spending from MT 58 billion in 2011 (50 percent of projected total expenditures excluding net lending) to MT 70 billion in 2012 (51 percent of projected total expenditures excluding net lending). Priority spending will be redefined to capture all spending under the new PARP's three main pillars (agriculture, job creation, social and human development) and supporting pillars (economic management and governance) following the completion of the programming exercise.

18. The Government reaffirms its strategy to promote investment in transportation and energy infrastructure. Such investment is expected to trigger a crowding in of private investment, thereby supporting our objective of achieving sustainable economic growth. We will maintain our prudent approach in selecting projects and give priority to those that promise a high economic return, especially to the extent that they are financed with nonconcessional resources under the program's ceiling of US\$900 million. We will pace the implementation of those projects such that they are compatible with macroeconomic stability and debt sustainability.

\section{The implementation of our salary policy will proceed at a measured pace} consistent with macroeconomic circumstances while safeguarding the recruitments needed in the priority sector. The Government will by end-March 2012 complete the review of the implementation strategy of the salary policy. Following the rollout of the e-Folha electronic salary payment system to three provincial directorates this year, we intend to complete the rollout to all provincial directorates by end-June 2012 (structural benchmark). We will continue to produce quarterly wage bill reports that will be used by the Ministries of Finance and Civil Service to monitor and control salary expenditure and eventually become an integral part of the integrated human resources management system.

\section{Structural Reforms}

\section{A. Public Financial Management and Reporting}

20. Reforms to improve the reporting, monitoring, and control of budget execution remain one of the pillars under the PSI. The following priority measures are underway:

- Expansion of budget coverage. The rollout of the e-SISTAFE budget execution system remains on track. The rollout plan adopted in September 2011 emphasizes cost effectiveness and focuses on entities that have (i) access to telecommunications, energy, and banks; (ii) a minimum budget size; and (iii) a minimum number of staff to operate the e-SISTAFE system. On this basis, we expect e-SISTAFE coverage to increase to 52 percent of all spending by end-2012, after 45 percent at end- 2011 . 
- Move toward IPSAS-compatible reporting. In line with recent TA, we are embarking on gradually reforming the state account format according to international public accounting standards (IPSAS) by 2015, for the State Account of 2014. Success of the reform will depend on strengthening capacity at the Accounting Directorate, as well as the approval by the MoF of a time-bound action plan on accounting reform by end-July 2012. As a first step toward IPSAS-compatible standard, we will improve the current State Account report, with due reconciliation and explanations, particularly in the area of debt accounts and transfers between the government and other institutions by end-June 2012 .

\section{B. Debt Management and Investment Planning}

21. The Government reiterates its commitment to make the newly created framework for debt management and investment planning an effective tool for our policy decisions. The Debt Management Committee (DMC) and Project Coordination Committee (PCC) will meet quarterly and issue regular reports to the respective supervising minister. The committees' deliberations will provide an increasingly comprehensive overview on proposed projects and their evaluation, as well as their implications for debt management. The Government will delay completion of the Integrated Investment Plan (a structural benchmark for end-December 2011) to end-March 2012 to allow staff from the Ministry of Plan and Development and line ministries to benefit from an upcoming capacity building workshop by the World Bank (WB). However, we will provide IMF staff with a first preliminary draft by end2011 that will provide first indications on prioritized high-return projects and how possible lower-cost alternatives to those projects (including through public-private partnerships) could be determined.

22. To further enhance the effective role played by both committees, we will take the following actions:

- Technical and reporting capacity at the DMC. The DMC will be further strengthened through additional training and enhanced technical capabilities in the MoF's debt unit. This will be key to improve and manage the underlying debt database, review new financing options, and draft and implement the medium-term debt strategy. The debt unit will produce accurate semi-annual debt reports to the DMC consistent with the format recommended by the recent TA. The new format includes cost and risk indicators comparable to those reported in the MTDS.

- Approval of Medium-Term Debt Strategy (MTDS). Drawing on recent capacity building by the IMF and the WB, the DMC will update the MTDS prepared earlier this year and bring it into a format that is consistent with macroeconomic circumstances and includes several borrowing scenarios and proposals to ensure smooth debt repayments. We will also aim to complete a second annual debt sustainability analysis by end-December 2011. The revised MTDS will be submitted, together with this second annual debt sustainability analysis, to the Council of Ministers by end-March 2012 for approval.

- Development of an annual domestic borrowing plan. Building on the MTDS, the DMC will draw up and publish a first annual domestic borrowing plan by end-June 2012 for the 
remainder of 2012. Upon approval of the 2013 budget law, an annual borrowing plan will be established for 2013. The plan will include quarterly financing and repayment projections and be consistent with the projected net annual financing needs and cash flow throughout the year.

- Strengthening of project selection processes. The PCC will aim to increase the quality of the information provided by line ministers to help them in their project evaluation efforts. It will supervise the effective application of the new project selection template. It will complement the template with an information requirement list for line ministries by end-February 2012 . With WB TA, a project preparation manual to further refine project selection guidelines will be drafted by end-March 2012. This will include the mapping of objectives and criteria for standardized project evaluation techniques to prioritize projects and to achieve the highest economic and social returns.

\section{Tax Administration}

23. We will persevere in our strong revenue mobilization effort while aiming to make the tax system more business-friendly. This will mainly be achieved by further modernizing tax administration.

- Development of single taxpayer database. The electronic tax payment project (e-tax) is now working with an adequate management and monitoring structure. On this basis, we will develop a new single taxpayer database and identification number, which we will initiate in October 2011 and make functional by end-June 2012 (structural benchmark). By end2012, 80 percent of corporate taxpayers and 30 percent of individual taxpayers should be registered under the new database.

- Tax payments through banks. The MoF will approve the Action Plan for Tax Payments through Banks by end-March 2012. The plan provides a detailed time-bound roadmap for the future collection of tax payments into the Single Treasury Account (CUT) under the single window (customs) and e-tax (domestic taxes) systems. This will enhance transparency, timely deposits in the CUT, and real-time consolidation of taxpayers' obligations.

- Rollout of single window trade facilitation project. Based on a pilot launched in September 2011, we aim to process by end-2012 all customs declarations at the country's seven main entry points through the single window system, and ensure payment of taxes and duties directly via banks. We expect that 70 percent of customs revenues be collected this way.

- Reinforcing of the large taxpayers unit (LTD-DCAT). Modern management procedures in the LTD-DCAT will continue to be reinforced with the creation of the "Taxpayer Manager", a dedicated liaison agent for large taxpayers. The unit also aims to build expertise in the hydrocarbons, energy and mineral coal areas to enable targeted audits. Revenue collection by the LTD-DCAT should increase from 47 percent of all revenues in 2010 to 52 percent in 2011, 58 percent in 2012, 64 percent in 2013, and 70 percent by end-2014. 


\section{Improving Natural Resource Management}

24. Mozambique remains determined to become a full-fledged EITI member in due course in line with our notable progress to improve the transparency of natural resource revenues. We will make every effort to complete and submit to the EITI the second country report, based on 2009 data, as quickly as possible to become EITI-compliant by the first possible opportunity. We will also forcefully address the recommendations from the first reconciliation and validation reports.

25. The Government is taking decisive steps to enhance its technical and institutional capacity to manage natural resources. We have been seeking expert advice from development partners to refine our mining and petroleum legislation. We also expect to benefit shortly from the IMF's new Topical Trust Fund for Managing Natural Resources Wealth to improve our fiscal regime, enhance revenue forecasts, and address newly emerged issues, such as on the valuation of minerals and the consideration of capital gains as a source of revenue. In the meantime, the Government continues to carefully analyze the feasibility for potential renegotiation of fiscal benefits in the natural resources sector with willing investors, while safeguarding the stability of the business climate in Mozambique.

\section{E. Fiscal Decentralization}

26. We will continue to decentralize fiscal responsibilities with due regard to local capacity, proper internal controls, and available financing. To this effect, we are gradually rolling out a district development monitoring system (Sistema de Monitoria do Desenvolvimento Distrital - SMdDD) aimed at assessing districts' administrative performance. Our goal is to assess 30 districts in 2011, 80 districts in 2012, and 128 districts in 2013. We will make these assessments public to local district councils and communities.

\section{F. Good Governance Framework}

27. The Government will ensure the proper implementation of the anti-corruption legislation upon its approval by Parliament. This will enhance the investment climate and instill confidence of local stakeholders. To this effect, the Government will update the 2006-10 Governance Anti-Corruption Strategy by end-June 2012, based on analysis and inputs from the recently completed Second National Study on Governance and Corruption Analysis, the 2009-14 Integrated Justice Strategy, and other relevant documents, including the report on the implementation of the African Peer Review Mechanism (MARP) in Mozambique. The Government will ensure that the updated strategy, including the essence of the underlying analysis and inputs, will be disseminated to, and discussed with, key stakeholders. Our PARP matrix will be revised accordingly to incorporate key actions under the strategy. 


\section{Financial Sector Policies}

\section{A. Fighting money laundering and terrorism financing}

28. The authorities are further strengthening the AML/CFT framework. The Financial Intelligence Unit (GIFIM) has begun its operations. It is now fully staffed and has received a full budget allocation under the 2012 budget law. However, the approval of the amended AML/CFT law is necessary to make the new framework fully effective and allow other regulators such as the BM to issue relevant guidelines in their respective areas. The draft legislation will be submitted to Parliament in December 2011. The MoF will establish, chair, and appoint the members of the high-level AML/CFT National Task Force by end- December 2011. Concurrently, GIFIM will prepare a national AML/CFT strategic plan to be approved by the Council of Ministers in 2012. The strategic plan will aim to foster national, regional, and international cooperation, strengthen the AML/CFT institutional framework, and promote capacity building and outreach efforts.

\section{B. Financial Sector Development Strategy (FSDS) for 2011-20}

29. We are in the process of launching Mozambique's Financial Sector Development Strategy (2011-20). Benefiting from the WB's technical support, the comprehensive strategy aims at enabling Mozambique to more efficiently finance long-term growth throughout the country, including in rural areas. It is supported by three strategic or operational bodies, and the terms of reference and the composition of the Steering Committee chaired by the MoF, the Technical Advisor Committee, and the coordinating Support Implementation Unit will be transmitted to the Minister of Finance for approval by end-November 2011. A seminar on the dissemination of the strategy will be held in February 2012. We will actively seek additional, and preferably pooled, support from development partners to finance the strategy's activities beyond June 2012 when WB financing (FSTAP) will come to an end.

\section{Financial Sector Surveillance}

\section{The BM will step up its financial surveillance in light of the renewed global} financial turbulence.

- Prudential supervision. Based on Fund TA, the BM plans to start conducting regular bank stress testing. It will re-assess liquidity risks in light of current tensions in the global banking system and strengthen the limitation of excessive concentration of liquid assets. With a view to adopting a risk-based approach to banking supervision, the BM will further move towards the migration of its prudential framework to Basel II by 2014.

- Financial sector contingency plan. The BM will ensure that the new financial sector contingency plan, to be completed by end-November 2011, is fully disseminated to the banking sector by end-February 2012.

- Deposit insurance. The MoF will approve the necessary regulations pertaining to such a scheme by end-April 2012 to ensure its timely implementation once its financing is secured. 
- Private pension system (INSS). With support from the ILO, we are committed to increase INSS' coverage while ensuring its financial stability and sustainability. These efforts will be guided by the results of the actuarial study (to be completed by end-May 2012), the recently published investment strategy, and our strong commitment to address the recently identified inaccuracies in the 2009 financial accounts.

\section{Program Monitoring}

31. The modified quantitative AC and indicative targets for end-December 2011, the indicative targets for end-March 2012, and the AC and indicative targets for end-June 2012 are shown in Table 1. Table 2 lists the structural benchmarks for the first half of 2012. The fourth PSI review is expected to be completed by end-June 2012 and the fifth PSI review by end 2012. 


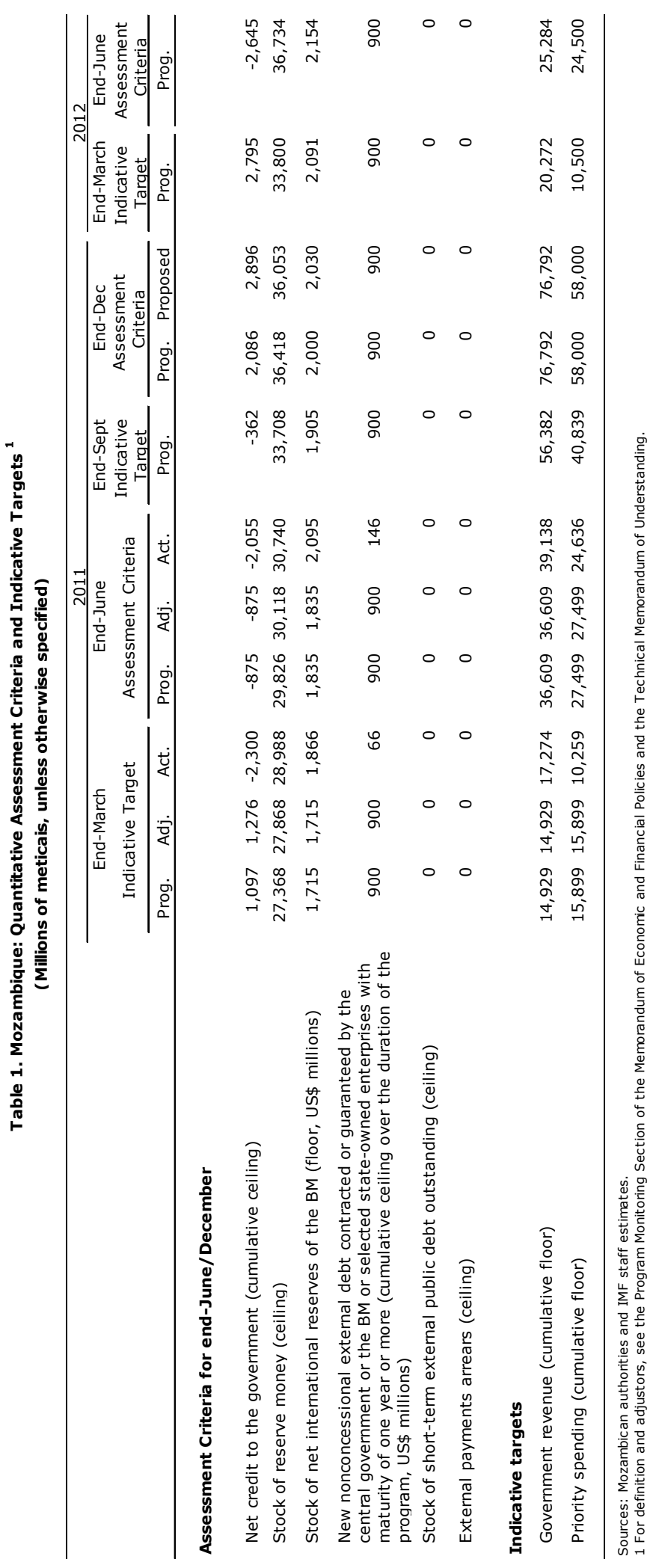


Table 2. Mozambique: Structural Benchmarks Under the PSI

\begin{tabular}{|c|c|}
\hline Structural Benchmarks & $\begin{array}{l}\text { Expected Date of } \\
\text { Implementation }\end{array}$ \\
\hline $\begin{array}{l}\text { The Minister of Planning and Development will approve an Integrated } \\
\text { Investment Program, in consultation with the Project Coordination } \\
\text { Committee, as described in paragraph } 25 \text { of the MEFP dated May } \\
20,2011 \text {. }\end{array}$ & End-March $2012^{1}$ \\
\hline $\begin{array}{l}\text { The Bank of Mozambique will publish its first quarterly monetary } \\
\text { policy report, as described in paragraph } 11 .\end{array}$ & End-May 2012 \\
\hline $\begin{array}{l}\text { The Government will complete the rollout of the e-Folha electronic } \\
\text { salary payment system to all provincial directorates, as described in } \\
\text { paragraph } 19 .\end{array}$ & End-June 2012 \\
\hline $\begin{array}{l}\text { The Ministry of Finance will make fully functional a new single } \\
\text { taxpayer database and identification number, as described in } \\
\text { paragraph } 23 \text {. }\end{array}$ & End-June 2012 \\
\hline $\begin{array}{l}\text { The Government will submit to Parliament an amendment to the } \\
\text { Corporate Income Tax Law reflecting measures derived from an } \\
\text { impact study on the equalization of the tax treatment between } \\
\text { Treasury bills and Government bonds and between collateralized } \\
\text { and uncollateralized interbank market operations, to take effect in } \\
2013 \text {, as described in paragraph } 10 \text {. }\end{array}$ & End-September 2012 \\
\hline
\end{tabular}

${ }^{1}$ Proposed to be delayed from end-December 2011 to allow officials in the Ministry of Plan and Development and line ministries to benefit from World Bank capacity building training on project selection. 


\section{AtTaChment 2: Technical Memorandum of Understanding}

November 14, 2011

1. This Technical Memorandum of Understanding (TMU) defines the quantitative assessment criteria, indicative targets, and structural benchmarks on the basis of which the implementation of the Fund-supported program under the Policy Support Instrument (PSI) will be monitored. In addition, the TMU establishes the terms and timeframe for transmitting the data that will enable Fund staff to monitor program implementation.

\section{DEFINITIONS}

\section{Net credit to the central government}

2. Net credit to the central government (NCG) by the banking system is defined as the difference between the outstanding amount of bank credits to the central government and the central government's deposits with the banking system, excluding deposits in project accounts with the banking system, recapitalization bonds issued to the Bank of Mozambique (BM), and proceeds from the signing fee for mineral resource exploration. Credits comprise bank loans, advances to the central government and holdings of central government securities and promissory notes. NCG will be calculated based on data from balance sheets of the monetary authority and commercial banks as per the monetary survey. The limits on the change in NCG by the banking system will be cumulative from end-December of the previous year.

3. The central government encompasses all institutions whose revenue and expenditure are included in the state budget (Orçamento do Estado): central government ministries, agencies without financial autonomy, and the administration of 11 provinces. Although local governments (43 municipalities or autarquias) are not included in the definition because they are independent, part of their revenue is registered in the state budget as transfers to local governments.

4. For program purposes, net disbursements on the nonconcessional Portuguese credit line are excluded from the assessment criterion of NCG since the corresponding expenditure is not covered under the definition of central government specified in paragraph 3.

\section{Government revenue and financing}

5. Revenue is defined to include all receipts of the General Directorate of Tax (Direcção Geral dos Impostos, DGI), the General Directorate of Customs (Direcção Geral das Alfândegas, DGA), and nontax revenue, including certain own-generated revenues of districts and some line ministries, as defined in the budget. Net receipts from privatization received by the National Directorate of State Assets (Direcção Nacional do Património do Estado) and unrealized profits transferred by the central bank to the treasury will not be considered as revenue (above the line) and will be accounted for as other domestic financing (below the line).

6. For the purpose of program monitoring, revenue is considered as collected at the time when it is received by the relevant government collecting agencies, in cash or checks, or through transfers into the respective bank account. 


\section{Priority social spending}

7. Priority social spending is based on the PARPA program categories. Accordingly, it will include total spending in the following sectors: (i) education; (ii) health; (iii) HIV/AIDS; (iv) infrastructure development; (v) agriculture; (vi) rural development; and (vii) governance and judicial system.

\section{Reserve money}

8. For the purposes of program monitoring reserve money is defined as the sum of currency issued by the BM and commercial banks' holdings at the BM. The target is defined in terms of the average of the daily end-of-day stocks in the month of the test date. The reserve money stock will be monitored and reported by the BM.

\section{Net international reserves}

9. Net international reserves (NIR) of the BM are defined as reserve assets minus reserve liabilities. The BM's reserve assets include (a) monetary gold; (b) holdings of SDRs; (c) reserve position at the IMF; (d) holdings of foreign exchange; and (e) claims on nonresidents, such as deposits abroad (excluding the central government's savings accounts related to mineral resource extraction concessions). Reserve assets exclude assets pledged or otherwise encumbered, including but not limited to assets used as collateral or guarantee for a third-party external liability (assets not readily available). The BM's reserve liabilities include: (a) all short-term foreign exchange liabilities to nonresidents with original maturity of up to and including one year; and (b) all liabilities to the IMF.

\section{New nonconcessional external debt contracted or guaranteed by the central government, the BM, and selected state-owned enterprises, with maturity of more than one year}

10. The ceiling on nonconcessional external debt applies to external debt contracted or guaranteed by the central government, the BM, the Road Fund, the water authorities (FIPAG), and the electricity company (EDM). It also applies to debt contracted by these three state-owned enterprises from domestic banks or from other state-owned enterprises that is contractually interrelated to external nonconcessional loans.

11. The ceiling applies to external debt with original maturity of one year or more and with a grant element below 35 percent. The grant element is calculated using currency-specific discount rates based on the Organization for Economic Cooperation and Development (OECD) commercial interest reference rates in accordance with the annual Budget Law. The term 'debt' will have the meaning set forth in Point 9 of the Guidelines on Performance Criteria with Respect to External Debt in Fund Arrangements adopted on August 3, 1979, as amended August 31, 2009, effective December 1, 2009. The concept of external debt is defined on the basis of the residency of the creditor. The ceiling also applies to commitments contracted or guaranteed for which value has not been received. This assessment criterion is defined cumulatively from the beginning of the program and will be assessed on a continuous basis. 


\section{Stock of short-term external public debt outstanding}

12. The central government will not contract or guarantee external debt with original maturity of less than one year. This assessment criterion applies not only to debt as defined in Point 9 of the Guidelines on Performance Criteria with Respect to External Debt in Fund Arrangements adopted on August 3, 1979, as amended August 31, 2009, effective December 1, 2009, but also to commitments contracted or guaranteed for which value has not been received. Excluded from this assessment criterion are short-term, import-related trade credits. This assessment criterion will be assessed on a continuous basis.

\section{External payments arrears}

13. The government undertakes not to incur payments arrears on external debt owed or guaranteed by the central government, with the exception of external payments arrears arising from government debt that is being renegotiated with creditors. This assessment criterion will be assessed on a continuous basis.

\section{Foreign program assistance}

14. Foreign program assistance is defined as grants and loans received by the Ministry of Finance through BM accounts excluding those related to projects (Table 1).

\section{Actual external debt service payments}

15. Actual external debt service payments are defined as cash payments on external debt service obligations of the government and central bank, including obligations to Paris Club and other bilateral creditors rescheduled under enhanced HIPC Initiative completion point terms, multilateral creditors, and private creditors, but excluding obligations to the IMF (Table 1).

\section{AdJUSTERS}

\section{Net international reserves}

16. The quantitative targets (floors) for net international reserves (NIR) will be adjusted:

- downward by the shortfall in external program aid less debt service payments (up to US\$100 million), compared to the program baseline (Table 1);

- downward/upward for any revision made to the end-year figures corresponding to the previous year; and

- downward to accommodate higher external outlays because of natural disasters, up to US\$20 million.

\section{Net credit to central government}

17. The quantitative targets (ceilings) for net credit to the central government (NCG) will be adjusted: 
- upward by the shortfall in the MT value of external program aid receipts less debt service payments (up to the MT equivalent of US\$100 million at exchange rates prevailing at the respective test dates), compared to the program baseline (Table 1);

- downward by privatization proceeds in excess of those envisaged in the program, unless these proceeds are deposited in the government's savings accounts abroad;

- downward (upward) for any increase (decrease) in domestic financing from the nonfinancial private sector; and

- upward to accommodate the higher locally-financed outlays because of natural disasters, up to the MT equivalent of US\$20 million at exchange rates prevailing at the respective test dates.

\section{Reserve money}

18. The quantitative target (ceiling) for reserve money will be adjusted upward by the excess of the stock of currency in circulation above the level envisaged in the program. For programming purposes, both the stocks of reserve money and currency in circulation are defined in terms of the average of the daily end-of-day stocks in the month of the test date. The target will be adjusted up to MT 750 million for end-December 2011 and up to MT 250 million for end-March, end-June, end-September and end-December 2012 (Table 1).

19. The ceiling on reserve money for every test date will be adjusted downward/upward to reflect decreases/increases in the legal reserve requirement on the liabilities in commercial banks. The adjuster will be calculated as the change in the reserve requirement coefficient multiplied by the amount of commercial banks' liabilities subject to reserve requirement, considered at the end of the period of constitution of the required reserves prior to the change in regulation.

\section{DATA AND OTHER REPORTING}

20. The Government will provide Fund staff with:

- monthly and quarterly data needed to monitor program implementation in relation to the program's quantitative targets and broader economic developments;

- $\quad$ weekly updates of the daily data set out in Table 1;

- weekly data set out in Table 4 of the TMU dated May 26, 2005;

- monthly updates of the foreign exchange cash flow of the BM;

- monthly data on government revenues (in detail according to the fiscal table) with a lag not exceeding one month;

- monthly information on the balance of government savings accounts abroad;

- monthly data on domestic arrears; 
- monthly data on external arrears;

- monthly budget execution reports (that will also be published) with a time lag not exceeding 45 days;

- the "mapa fiscal" with a time lag not exceeding 60 days;

- monthly monetary survey data with a time lag not exceeding 30 days;

- monthly data on gross international reserves, with the composition by original currencies and converted to US dollars at the actual exchange rates; and

- quarterly balance-of-payments data with a time lag not exceeding 65 days.

- monthly disbursements on the nonconcessional Portuguese credit line with a time lag not exceeding 30 days.

21. The monetary survey made available by the BM will clearly identify donor-financed project deposits (with a breakdown between foreign and domestic currency) included in net credit to the government in both the central bank's and commercial banks' balance sheets.

22. The government will provide Fund staff with documentation concerning external loan agreements once these have been signed and become effective. 
TMU Table 1. Mozambique: Net Foreign Assistance, 2011-12

\begin{tabular}{|c|c|c|c|c|c|c|c|c|}
\hline & \multicolumn{6}{|c|}{2011} & \multicolumn{2}{|c|}{2012} \\
\hline & \multicolumn{2}{|c|}{ Q1 } & \multicolumn{2}{|c|}{ Q2 } & \multirow{2}{*}{$\begin{array}{r}\text { Q3 } \\
\text { Prog. }\end{array}$} & \multirow{2}{*}{$\begin{array}{r}\text { Q4 } \\
\text { Prog. }\end{array}$} & \multirow{2}{*}{$\begin{array}{c}\text { Q1 } \\
\text { Prog. }\end{array}$} & \multirow{2}{*}{$\begin{array}{c}\text { Q2 } \\
\text { Prog. }\end{array}$} \\
\hline & Prog. & Act. & Prog. & Act. & & & & \\
\hline Net foreign program assistance (US\$ mn) & 129 & 145 & 126 & 138 & 104 & 36 & 70 & 198 \\
\hline Gross foreign program assistance & 144 & 160 & 140 & 153 & 119 & 51 & 94 & 222 \\
\hline Program grants & 144 & 160 & 140 & 153 & 119 & 19 & 94 & 137 \\
\hline Program loans & 0 & 0 & 0 & 0 & 0 & 32 & 0 & 85 \\
\hline External debt service & 15 & 15 & 15 & 15 & 15 & 15 & 24 & 24 \\
\hline Net foreign program assistance (MT mn) & 4,732 & 4,552 & 3,802 & 4,072 & 3,170 & 925 & 2,032 & 5,931 \\
\hline Gross foreign program assistance & 5,253 & 5,075 & 4,337 & 4,600 & 3,693 & 1,433 & 2,753 & 6,685 \\
\hline Program grants & 5,253 & 5,075 & 4,337 & 4,600 & 3,693 & 547 & 2,753 & 4,125 \\
\hline Program loans & 0 & 0 & 0 & 0 & 0 & 886 & 0 & 2,560 \\
\hline External debt service & 521 & 523 & 535 & 528 & 523 & 508 & 722 & 754 \\
\hline Stock of outstanding currency (MTm) & 16,098 & 17,107 & 19,164 & 19,083 & 22,512 & 23,650 & 21,230 & 23,272 \\
\hline Stock of outstanding currency (MTm), Prog. Def & 15,878 & 17,323 & 18,430 & 18,721 & 21,901 & 23,600 & 21,499 & 22,830 \\
\hline
\end{tabular}

Source: Mozambican authorities and IMF staff estimates. 


\section{Appendix II. The IMPACT OF MEgaprojects ON GROWTH IN MOZaMbiQUe ${ }^{1}$}

Megaprojects have made an important contribution to Mozambique's economic success over the past decade. With the start of operations of the coal projects in Tete in 2011 and the upcoming expansion of natural gas production, they show the potential to also drive economic growth going forward. Using macro and micro data, we estimate the direct impact of megaprojects on GDP at factor costs. Preliminary estimates suggest that mega-projects could potentially boost growth by as high as 2 to 4 percentage points annually and directly contribute up to 18 percent of total value added by 2016.

\section{OVERVIEW OF MEGAPROJECTS}

\section{Megaprojects are large foreign-owned and capital-intensive island-type activities} that rely on extracted resources and/or imported intermediate goods, and export almost all of their production. At the moment, there are six megaprojects in operation in Mozambique (Table 1): (i) the hydroelectric power generation station Cahora-Bassa; (ii) the Mozal aluminum smelter; (iii) the Sasol natural gas extraction plant; (iv) the Kenmare heavy sands project; (v) the Vale coal mine; and (vi) the Rio-Tinto coal mine. Sasol and Kenmare started expanding capacity in 2011; Mozal and Cahora-Bassa are considering expansions in the near future. In addition, several projects are currently in the exploration and development stage, including: (i) construction of a dam and power generation unit at Mphanda-Nkuwa; (ii) oil and gas exploration by Anadarco, ENI, Statoil and Pteronas; (iii) JSPL coal exploration; and (iv) exploration of heavy sands in Chibuto.

2. A broad picture on the role of megaprojects emerges from national account data on the value added of the secondary sector (Figure 1). Such data are available at a longer time horizon than individual project data and form the basis of this analysis. The re-launching of power generation at Cahora-Bassa in December 1997, as the transmission lines destroyed during the civil war were restored, boosted GDP growth by 21/2 percentage points in both 1998 and 1999. The launch of Mozal I contributed close to 2 and 4 percentage points of GDP growth in 2000 and 2001, respectively. Complementing the analysis, the detailed available megaproject data on value added for 2002-2010 show that the share of megaprojects in the value added of the secondary sector increased by about one-third during the period, from close to 37 percent in 2002 to 48 percent in 2010. The contribution of the secondary sector to value added growth was on average 1.8 percent in the 1990 s and 2.1 percent in the 2000 s.

\footnotetext{
${ }^{1}$ Prepared by Katsiaryna Svirydzenka (AFR).
} 
Table 1. List of Mega-Projects

\begin{tabular}{|c|c|c|c|c|c|}
\hline Company name & Sector & Location (city, province) & Capacity/reserves & Construction & Production \\
\hline \multicolumn{6}{|c|}{ Current and extensions under consideration } \\
\hline $\begin{array}{l}1 \text { Hydroelectrica } \\
\text { Cahora Bassa (HCB) } \\
\text { HCB } \\
\text { HCB_North }\end{array}$ & $\begin{array}{l}\text { electricity } \\
\text { generation }\end{array}$ & Cahora Bassa, Tete & $\begin{array}{l}2,075 \mathrm{MW} \\
1,240 \mathrm{MW}\end{array}$ & $1995-97$ & 1998 \\
\hline $\begin{array}{l}2 \text { Mozal } \\
\text { Mozal I } \\
\text { Mozal II } \\
\text { Mozal III }\end{array}$ & $\begin{array}{l}\text { aluminium } \\
\text { smelter }\end{array}$ & $\begin{array}{l}\text { Beluluale Industrial Park, } \\
\text { Maputo }\end{array}$ & $\begin{array}{l}245 \text { thousand tons } \\
245 \text { thousand tons }\end{array}$ & $\begin{array}{l}1998-2000 \\
2001-2003\end{array}$ & $\begin{array}{l}2000 \\
2003\end{array}$ \\
\hline 3 Sasol & natural gas & $\begin{array}{l}\text { Pande and Temane gas } \\
\text { fields, Inhambane }\end{array}$ & $154 \mathrm{GJ}$ & $2002-2004$ & 2004 \\
\hline $50 \%$ expansion & & & $183 \mathrm{GJ}$ & 2011 & $\begin{array}{l}\text { ramp up by } \\
2016\end{array}$ \\
\hline 4 Kenmare & heavy sands & Moma, Nampula & & 2004 & 2007 \\
\hline 5 Vale (CVRD) & coal & Moatize mine, Tete & $\begin{array}{l}25 \text { million tons per } \\
\text { year }\end{array}$ & $2007-2011$ & 2011 \\
\hline 6 Rio Tinto & coal & Benga mine, Tete & $\begin{array}{l}38 \text { million tons per } \\
\text { year }\end{array}$ & & 2012 \\
\hline \multicolumn{6}{|l|}{ Under consideration } \\
\hline 1 Mphanda Nkuwa & electricity & Zambesi river, Tete & $1500 \mathrm{MW}$ & $2011-2015$ & \\
\hline 2 Anadarko (US), & natural gas & Rovuma basin & $\begin{array}{l}10 \text { trillion cubic } \\
\text { feet }\end{array}$ & & \\
\hline ENI (Italy), & & & $\begin{array}{l}15 \text { trillion cubic } \\
\text { feet }\end{array}$ & & \\
\hline \multicolumn{6}{|l|}{ Statoil (Norway), } \\
\hline \multicolumn{6}{|l|}{ Petronas (Malaysia) } \\
\hline 3 JSPL & coal & Changara district, Tete & 10 million tons & & $\begin{array}{l}\text { 2012-2016 } \\
\text { ramp up }\end{array}$ \\
\hline 4 Corridor Sands & heavy sands & Chibuto, Gaza province & & & \\
\hline
\end{tabular}


Figure 1. Megaprojects and the Secondary Sector

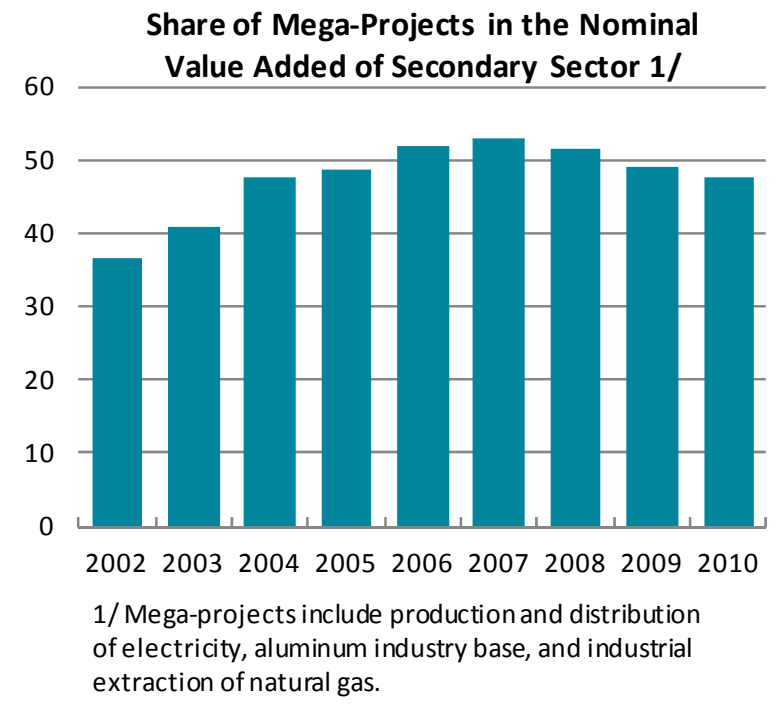

Source: National Accounts.

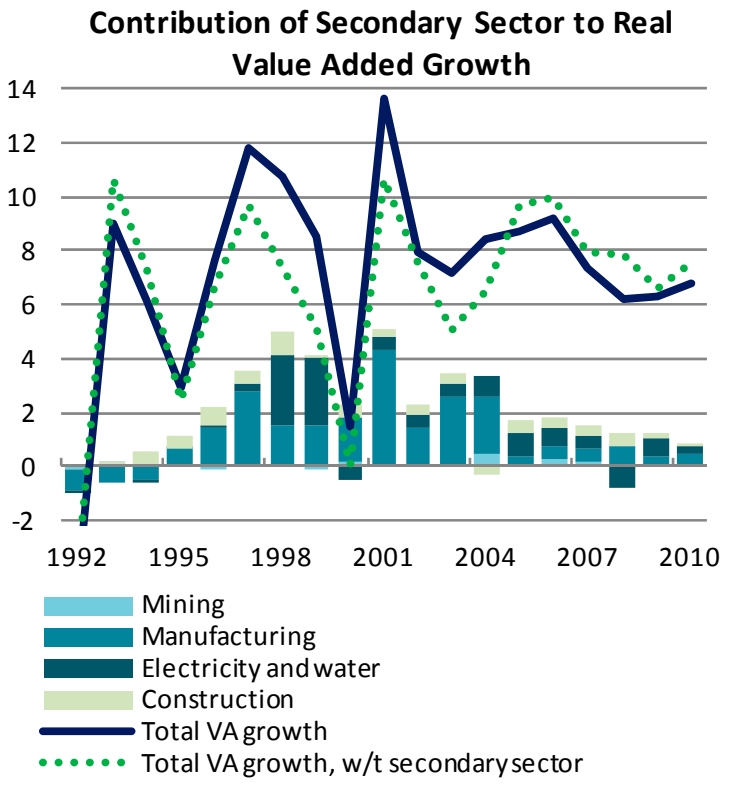

\section{IMPACT ON VALUE ADDED}

Historically, the ramp-up of a megaproject to full capacity contributed up to 4 percentage points to GDP growth annually.

3. We estimate the contribution of megaprojects to growth in GDP at factor costs. GDP at factor costs is the sum of industry value added, abstracting from the indirect taxes and production subsidies. Value added equals the difference between an industry's gross output (consisting of sales or receipts and other operating income, adjusted for commodity taxes and inventory change) and the cost of its intermediate inputs (including energy, raw materials, semifinished goods, services that are purchased from all sources). Because of the difficulty in estimating deflators for intermediate consumption, instead of using the double deflation method, we assume that the shares of nominal and real coal value added in gross value added are equal.

\section{During 2003-10, megaprojects contributed up to 4 percentage points to the growth}

of value added. Given that their output is limited by capacity constraints, there is a certain dynamics to the role the megaprojects play in macroeconomic aggregates. When they start operating and until they reach full capacity, megaprojects boost growth. For example, the doubling of Mozal capacity in 2003-04 boosted total value added growth by over 2 percentage points (Figure 2). The sheer magnitude of Mozal's operations and its ability to reach full capacity within one year were behind such growth spurts. However, once a mega-project reaches its capacity, its output does not grow anymore. As a result, its contribution to growth disappears and its share in value-added tends to decrease somewhat over time as other sectors with positive growth rates overtake it. Thus, the ability of megaprojects to be a continuous growth engine depends on the launch of new projects and on the expansion of their capacity, as is the case in Mozambique at the moment, as well as on stronger reliance on domestically-produced goods and services and subcontracting, which affects growth through indirect channels. 
Figure 2. Direct Impact of Current Megaprojects on Value Added
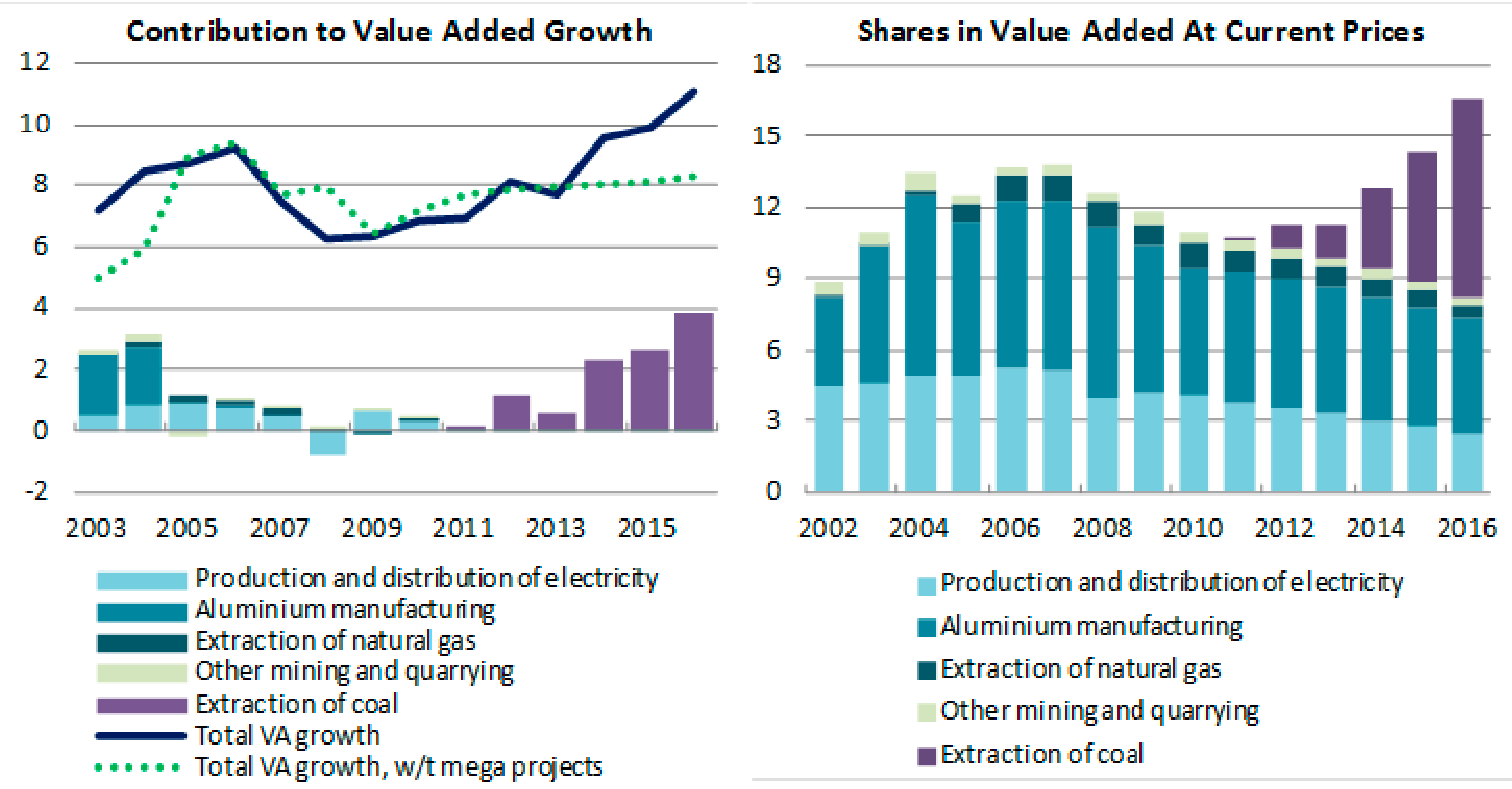

Source: National Accounts, and staff calculations.

In the medium term, the contribution of megaprojects is likely to increase.

5. Assumptions for the projection horizon are as follows. The counterfactual growth scenario assumes that sector growth rates remain at their 2010 level, which results in a linear growth path of GDP at factor costs rising from 6.8 percent in 2010 to 7.6 percent in 2016 . The expansion in mega-project production incorporates the 50 percent linear ramp-up in Sasol capacity by 2016 and the start of coal production by Vale in 2011 and Rio-Tinto in 2012, each reaching projected full capacity by 2016 and 2020, respectively.

6. Coal production is heavily dependent on infrastructure constraints. Current reserve estimates suggest an annual production capacity of 25 million tons from the Moatize mine of Vale and 45 million tons from the Benga, Zambeze and Tete East mines of Rio-Tinto. However, there are infrastructure constraints on getting the coal output to world markets. The current capacity of the Sena railway linking Tete province with Beira port is limited to 2 million tons due to the poor state of the line relative to an estimated possible full capacity load of 6 million tons. CFM, the ports and railways company, expects to complete the refurbishment of the line by early 2013, which would boost Vale and Rio-Tinto's outputs to 4.3 and 1.5 million tons, respectively, in that year. Vale is engaged in constructing another railway line to Nacala port, which would allow it to produce at full capacity and is expected to be completed by 2015 . RioTinto is awaiting the results of the environmental impact review and feasibility studies on barging on the Zambezi river, which, if the studies are successful, would start as early as 2014 and would lift Rio-Tinto's output to over 10 million tons. The construction of an additional rail line on the right bank of the Zambezi river, if judged feasible, would allow Rio-Tinto to reach full capacity by 2020. These assumptions on infrastructure developments - the upgrade of the Sena line by 2013, the start of barging in 2014, and the becoming operational of the Nacala line by 2016 - underlie the projections of coal output for the two companies. 
7. If the infrastructure developments proceed according to plans, the growth in the coal industry will boost the share of the megaprojects to up to 18 percent of the value added by 2016 (Figure 2). The direct contribution to GDP growth is estimated to hover between 2 to 4 percentage points annually. The doubling of the Sasol capacity does not boost growth to the same degree due to its relatively low share in value added. This is likely to change as the large gas discoveries by Anadarko and ENI start to get explored later in the decade.

8. However, megaprojects will not create significant employment. Historically, megaprojects' contribution to employment has been small. In 2010, they are estimated to have employed close to 3,800 people, compared to a total employment of 10.2 million and population of 23.4 million. Once the coal mines reach capacity by 2016 , they are expected to additionally employ close to 7,000 domestic employees, bringing the share of megaprojects in total employment to 0.01 percent.

\section{References}

Andersson, P.. 2001. "The impact of the mega projects on the Moçambican economy." GEST Discussion paper, No. 18.

Castel-Branco, C., 2003. "Impacts of the Mozal Aluminium Smelter on the Mozambican Economy.” Relatório apresentado à Mozal. Maputo.

Clement, J. and S. Peiris (eds.), 2007. Post-Stabilization Economics in Sub-Saharan Africa: Lessons from Mozambique. International Monetary Fund (IMF), 2007.

Sonne-Schmidt, C., Arndt, C. and M. Mag, 2009. "Contribution of Mega-Projects to GPD in Mozambique.” II Conferência IESE “Dinâmicas da Pobreza e Padrões de Acumulação Económica em Moçambique." 


\title{
INTERNATIONAL MONETARY FUND
}

REPUBLIC OF MOZAMBIQUE

\section{Third Review Under the Policy Support Instrument and Request for Modification of Assessment Criteria- Informational Annex}

\author{
Prepared by the African Department \\ (In consultation with other departments)
}

November 18, 2011

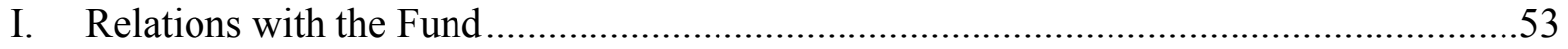

II. World Bank-IMF Collaboration.............................................................................61

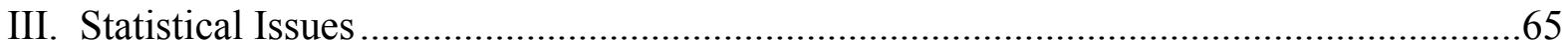




\section{APPENDIX I. MOZAMbIQUE: RELATIONS WITH THE FUND}

(as of September 30, 2011)

I. Membership Status ${ }^{5}$ : Joined: September 24, 1984;

Article VIII

II. General Resources Account:

SDR Million

113.60

113.60

0.01

Reserve Position

III. SDR Department:

Net cumulative allocation

Holdings

IV. Outstanding Purchases and Loans:

ESF Arrangements

ECF Arrangements
SDR Million

108.84

107.67

SDR Million

113.60

8.77

Expiration

Date

Jun 28,2010

Jul 05, 2007

Jun 28, 2003
113.60
\%Allocation

100.00

98.93

\%Quota

100.00

7.72
Amount Drawn

(SDR Million)

113.60

11.36

78.80

\section{Projected Payments to Fund ${ }^{7}$}

(SDR Million; based on existing use of resources and present holdings of SDRs):

Principal

Charges/Interest

Total

Jul 06, 2004

Jun 28, 1999
Forthcoming

\begin{tabular}{lllll}
\hline$\underline{2011}$ & $\underline{2012}$ & $\underline{2013}$ & $\underline{2014}$ & $\underline{2015}$ \\
0.16 & 1.46 & 1.95 & 1.95 & 23.09 \\
$\underline{0.00}$ & $\underline{0.31}$ & $\underline{0.30}$ & $\underline{0.30}$ & $\underline{0.26}$ \\
$\underline{0.16}$ & $\underline{1.77}$ & $\underline{2.25}$ & $\underline{2.25}$ & $\underline{23.35}$
\end{tabular}

${ }^{5}$ On May 20, 2011, the authorities accepted the obligations under Article VIII of the Fund's Articles of Agreement.

${ }^{6}$ Former PRGF.

${ }^{7}$ When a member has overdue financial obligations outstanding for more than three months, the amount of such arrears will be shown in this section. 
VII. Implementation of HIPC Initiative:

I. Commitment of HIPC assistance

Decision point date

\begin{tabular}{rr}
$\begin{array}{rr}\text { Original } \\
\text { Framework }\end{array}$ & $\begin{array}{r}\text { Enhanced } \\
\text { Framework }\end{array}$ \\
\hline Apr 1998 & Apr 2000 \\
& \\
$1,716.00$ & 306.00 \\
124.60 & 18.46 \\
93.17 & 13.73
\end{tabular}

Assistance committed

by all creditors (US\$ Million) ${ }^{8}$

Of which: IMF assistance (US\$ million)

(SDR equivalent in millions)

Jun. 1999 Sep. 2001

Completion point date

II. Disbursement of IMF assistance (SDR Million)

Assistance disbursed to the member

93.17

13.73

106.90

Interim assistance

2.31

2.31

Completion point balance

93.17

11.42

104.58

Additional disbursement of interest income ${ }^{9}$

1.10

1.10

Total disbursements

93.17

14.83

108.00

\section{Implementation of Multilateral Debt Relief Initiative (MDRI):}

I. MDRI-eligible debt (SDR Million) ${ }^{10}$

106.56

Financed by: MDRI Trust

83.05

Remaining HIPC resources

23.51

II. Debt Relief by Facility (SDR Million)

Eligible Debt

Delivery Date

January 2006

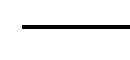

$\underline{\text { GRA }}$

N/A $\underline{\text { PRGF }}$

106.56 $\underline{\text { Total }}$

106.56

\footnotetext{
${ }^{4}$ Assistance committed under the original framework is expressed in net present value (NPV) terms at the completion point, and assistance committed under the enhanced framework is expressed in NPV terms at the decision point. Hence these two amounts cannot be added.

${ }^{5}$ Under the enhanced framework, an additional disbursement is made at the completion point corresponding to interest income earned on the amount committed at the decision point but not disbursed during the interim period.

${ }^{6}$ The MDRI provides 100 percent debt relief to eligible member countries qualified for the assistance. Grant assistance from the MDRI Trust and HIPC resources provide debt relief to cover the full stock of debt owed to the Fund as of end-2004 outstanding at the time the member qualifies for debt relief.
} 


\section{Safeguards assessment}

An update safeguards assessment of the Bank of Mozambique (BM) was completed on January 11, 2010 for the ESF. The assessment found improvements in financial reporting practices following the implementation of IFRS. It noted vulnerabilities in the oversight mechanism for external and internal auditing, controls, financial reporting, and in the BM's legal structure. It recommended that the BM commission an external quality assurance review of the internal audit function. Staff will follow-up on progress in implementing the assessment's recommendations.

\section{Exchange arrangement}

Mozambique has a de jure and de facto floating exchange rate arrangement. The exchange rate is largely determined in the interbank foreign exchange market (MCI). The BM regularly intervenes in the market to smooth seasonal fluctuations, provide foreign exchange liquidity received by the government in the form of aid, and sterilize domestic liquidity as part of its monetary policy operations.

On May 20, 2011, Mozambique accepted its obligations under Article VIII, Sections 2, 3, and 4 of the Fund's Articles of Agreement (EBD/11/34). A new foreign exchange law_-"Foreign Exchange Law" Law No. 11/2009_came into effect on March 11, 2009. A new foreign exchange regulation to implement the foreign exchange law - the "Regulation for the Foreign Exchange Law" (the "Regulation") (Decreto No. 83/2010)—was issued on December 31, 2010. The Regulation, in conjunction with the implementing norms subsequently issued by the BM, fully removed the existing exchange restrictions subject to Article VIII, Sections 2, 3, and 4 of the Fund's Articles of Agreement. The two existing multiple currency practices (MCP) were also removed in March and April 2011, respectively, through the adoption of a new regulation on the interbank exchange market and by discontinuing the previous multiple price foreign exchange auction system, which in any case had not been used since 2009.

\section{AML/CFT framework}

Mozambique's first AML/CFT Mutual Evaluation Report by the Eastern and Southern Africa Anti-Money Laundering Group (ESAAMLG) has been formally adopted by ESAAMLG and should be published shortly. Based on the deficiencies identified in the report, the Financial Action Task Force's (FATF) International Co-operation Review Group (ICRG) maintains Mozambique in a pool of jurisdictions which may be taken up for review. This process is designed to publicly identify high-risk jurisdictions, and could ultimately result in a public statement by the FATF to apply counter-measures. In order to improve compliance with the FATF 40+9 Recommendations, the Financial Intelligence Unit (GIFIM) has been staffed and has begun its operations. Once the AML/CFT law is approved by Parliament, the BM intends to issue implementing guidelines. In order to ensure a consistent application of the AML/CFT framework across various regulators, the Government intends to establish, and appoint the members of, the National AML Task Force by end-November 2011.

\section{Article IV consultation}


In accordance with Decision No 12794-(02/76), as amended by Decision No 12854-(02/96), Mozambique is on a 24-month Article IV cycle due to the approval of the successor PSI in June 2010. The 2011 Article IV consultation was completed by the Executive Board on June 17, 2011 (Country Report No. 11/149).

In concluding the 2011 Article IV consultation, Executive Directors commended the authorities for their prudent policies that have resulted in a strong economic performance. They noted that, although Mozambique's medium-term prospects continue to be favorable, significant challenges remain in managing macroeconomic risks and ensuring that the benefits from growth are shared fairly across the population. In this regard, Directors underscored that safeguarding price stability and containing inflation expectations remain key policy priorities for the period ahead. They welcomed the authorities' new Poverty Reduction Strategy (PARP), including its focus on continued structural reforms to improve productivity and production in labor-intensive sectors such as agriculture, create jobs through improvements in the business environment, and pursue social and human development. These focus areas will be important to achieve sustained growth and poverty reduction. Directors supported the authorities' prudent fiscal stance aimed at preserving macroeconomic stability and debt sustainability, and encouraged the authorities to adopt a prudent approach to generating additional budgetary revenue from the natural resource sector while protecting Mozambique as a destination for foreign investment. Directors emphasized the importance of adhering to a prudent borrowing strategy, further strengthening debt management, and improving investment planning. They noted the resilience of the banking system during the global crisis, and recommended continued vigilance in light of remaining vulnerabilities.

\section{Ex post assessment of performance under Fund-supported programs}

An ex post assessment (EPA) of Mozambique's performance under Fund-Supported Programs since 1987 was undertaken in December 2003 under the guidelines on assessments of countries with a longer-term program engagement. The EPA was circulated to the Executive Board on November 21, 2003 (Country Report No. 04/53).

Directors commended the authorities for their pursuit of sound macroeconomic policies and wide ranging structural reforms over the past fifteen years which contributed to strong growth of the economy, and a steady decline in poverty rates. Noting that despite considerable progress Mozambique remains a very poor and vulnerable country, Directors urged the authorities to persevere in their efforts to consolidate macroeconomic stability and accelerate and deepen structural reforms with a view to sustaining economic growth, encouraging employment creation, and further reducing poverty.

\section{FSAP participation and ROSCs}

A Financial Sector Assessment Program (FSAP) for Mozambique was undertaken during the first quarter of 2003. The related Financial Sector Stability Assessment was circulated to the Executive Board on November 19, 2003 (Country Report No. 04/52). An update to the FSAP 
took place in February 2009 and the related Financial Sector Stability Assessment circulated to the Board on June 19, 2009 (Country Report No. 10/12) A ROSC on fiscal transparency was issued on February 22, 2001. This ROSC was updated in the context of the 2002 Article IV consultation (Country Report No. 02/140) and the 2003 Article IV Consultation (Country Report No. 04/50). The ROSC on fiscal transparency was updated in May 2008. A Report on the Observance of Standards and Codes (ROSC) data module was prepared in June 2002 and issued on March 5, 2003. This data module was updated in August 2005.

\section{Management's visit}

At the invitation of the authorities, Mr. Kato, Deputy Managing Director, visited Maputo, Mozambique in July 2005. The Managing Director visited Mozambique on August 2007 for a meeting with the African Consultative Group on Quotas, Voice, and Representation.

\section{Resident representative}

Mr. Victor Lledo has been the IMF's resident representative to Mozambique since June 21, 2010. 


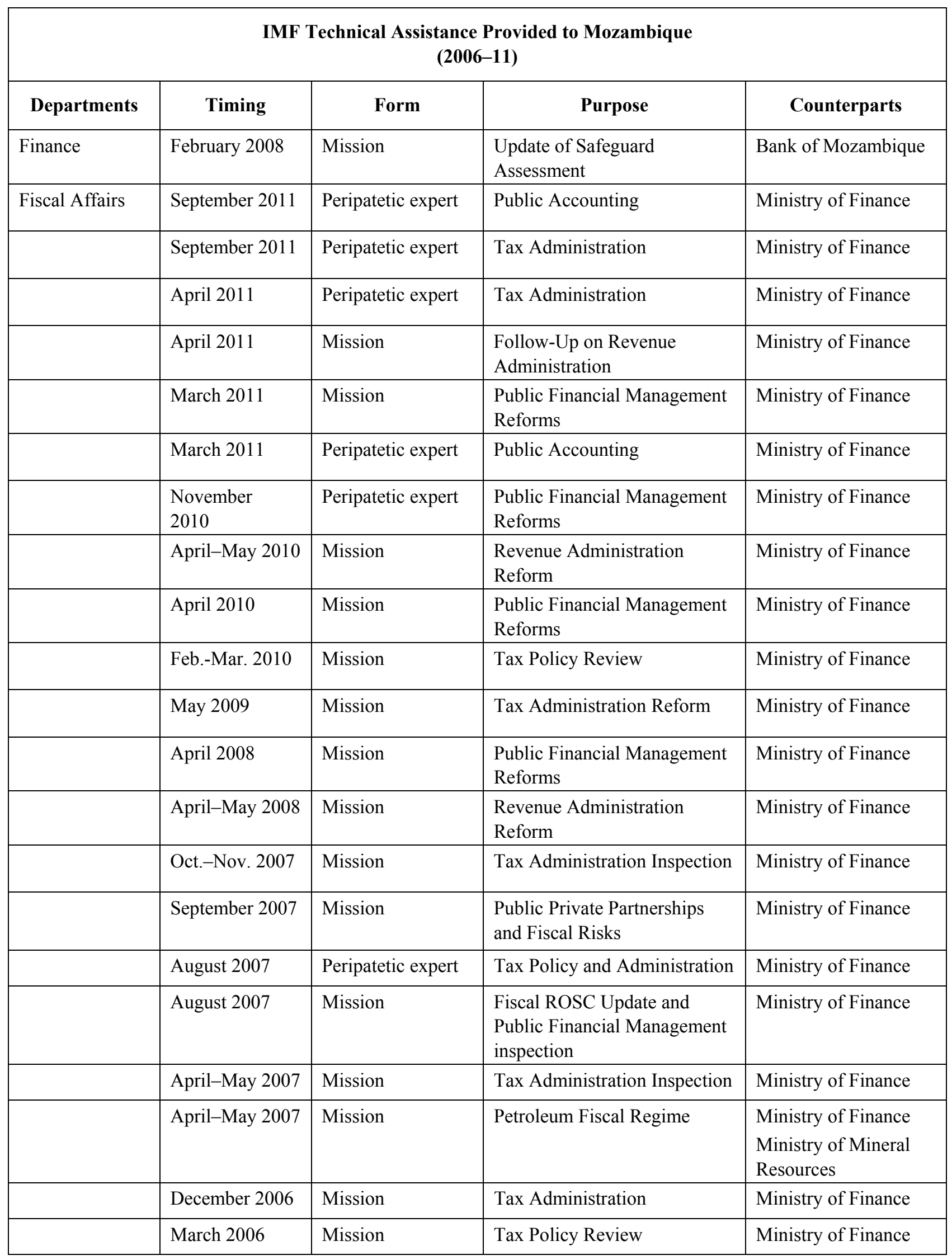




\begin{tabular}{|c|c|c|c|c|}
\hline \multicolumn{5}{|c|}{$\begin{array}{l}\text { IMF Technical Assistance Provided to Mozambique } \\
\qquad(2006-11)\end{array}$} \\
\hline Departments & Timing & Form & Purpose & Counterparts \\
\hline \multirow[t]{15}{*}{$\begin{array}{l}\text { Monetary and } \\
\text { Capital Markets }\end{array}$} & September 2011 & Mission & $\begin{array}{l}\text { Follow-up on Medium-Term } \\
\text { Debt Strategy and Capacity to } \\
\text { Conduct Debt and Project } \\
\text { Analysis }\end{array}$ & $\begin{array}{l}\text { Minister of Finance } \\
\text { Bank of Mozambique }\end{array}$ \\
\hline & August 2011 & Mission & Monetary Policy Framework & Bank of Mozambique \\
\hline & September 2010 & Mission & $\begin{array}{l}\text { Follow-up on Medium-Term } \\
\text { Debt Strategy, Debt Markets, } \\
\text { and Capacity to Conduct Debt } \\
\text { and Project Analysis }\end{array}$ & $\begin{array}{l}\text { Minister of Finance } \\
\text { Bank of Mozambique }\end{array}$ \\
\hline & June 2010 & Mission & $\begin{array}{l}\text { Medium-Term Debt Strategy, } \\
\text { Debt Markets, and Capacity to } \\
\text { Conduct Debt and Project } \\
\text { Analysis }\end{array}$ & $\begin{array}{l}\text { Minister of Finance } \\
\text { Bank of Mozambique }\end{array}$ \\
\hline & April 2010 & Mission & $\begin{array}{l}\text { Strengthening Monetary } \\
\text { Policy Formulation and } \\
\text { Implementation }\end{array}$ & Bank of Mozambique \\
\hline & November 2009 & Mission & $\begin{array}{l}\text { Strengthening Monetary } \\
\text { Policy Formulation and } \\
\text { Implementation }\end{array}$ & Bank of Mozambique \\
\hline & May 2009 & Mission & 2009 FSAP Follow up & Bank of Mozambique \\
\hline & February 2009 & Mission & $\begin{array}{l}\text { TA on Central Banking and } \\
\text { Monetary Policy Formulation }\end{array}$ & Bank of Mozambique \\
\hline & May 2008 & Mission & $\begin{array}{l}\text { Strengthening Monetary } \\
\text { Policy Formulation and } \\
\text { Implementation }\end{array}$ & Bank of Mozambique \\
\hline & December 2007 & Mission & $\begin{array}{l}\text { Implementation of IFRS for } \\
\text { Central Bank Accounts. }\end{array}$ & Bank of Mozambique \\
\hline & August 2007 & Mission & $\begin{array}{l}\text { Post-FSAP TA Assessment: } \\
\text { Banking supervision, } \\
\text { Monetary Policy and } \\
\text { Operations }\end{array}$ & Bank of Mozambique \\
\hline & April 2007 & $\begin{array}{l}\text { Short-term } \\
\text { consultant }\end{array}$ & Banking Supervision & Bank of Mozambique \\
\hline & October 2006 & Mission & $\begin{array}{l}\text { Post-FSAP TA Assessment: } \\
\text { Banking supervision, } \\
\text { Monetary Policy and } \\
\text { Operations }\end{array}$ & Bank of Mozambique \\
\hline & Feb-March 2006 & Mission & AML/CFT legislation & Bank of Mozambique \\
\hline & Jan-Feb 2006 & $\begin{array}{l}\text { Short-term } \\
\text { consultant }\end{array}$ & Monetary Policy Framework & Bank of Mozambique \\
\hline
\end{tabular}


IMF Technical Assistance Provided to Mozambique

(2006-11)

\begin{tabular}{|c|c|c|c|c|}
\hline Departments & Timing & Form & Purpose & Counterparts \\
\hline & Jan-Feb 2006 & $\begin{array}{l}\text { Short-term } \\
\text { consultant }\end{array}$ & Monetary Operations & Bank of Mozambique \\
\hline & January 2006 & $\begin{array}{l}\text { Short-term } \\
\text { consultant }\end{array}$ & Exchange Rate Management & Bank of Mozambique \\
\hline \multirow[t]{8}{*}{ Statistics } & February 2010 & Mission & Multitopic GDDS & $\begin{array}{l}\text { National Institute of } \\
\text { Statistics }\end{array}$ \\
\hline & $\begin{array}{l}\text { March-April } \\
2008\end{array}$ & Mission & National Accounts Statistics & $\begin{array}{l}\text { National Institute of } \\
\text { Statistics }\end{array}$ \\
\hline & February 2008 & Mission & Balance of Payments Statistics & Bank of Mozambique \\
\hline & December 2007 & Mission & Balance of Payments Statistics & Bank of Mozambique \\
\hline & November 2007 & Mission & $\begin{array}{l}\text { Monetary and Financial } \\
\text { Statistics }\end{array}$ & Bank of Mozambique \\
\hline & June-July 2006 & Mission & Consumer Price Statistics & $\begin{array}{l}\text { National Institute of } \\
\text { Statistics (INE) }\end{array}$ \\
\hline & $\begin{array}{l}\text { August } 2005- \\
\text { July } 2006\end{array}$ & $\begin{array}{l}\text { Long-term } \\
\text { consultant }\end{array}$ & National Accounts Statistics & $\begin{array}{l}\text { National Institute of } \\
\text { Statistics }\end{array}$ \\
\hline & July 2005 & Mission & Government Finance Statistics & $\begin{array}{l}\text { National Institute of } \\
\text { Statistics }\end{array}$ \\
\hline
\end{tabular}




\section{APPENDIX II. WORLD BANK-IMF COLLABORATION}

9. The Fund Mozambique team met with the World Bank Mozambique team in Maputo during the third PSI review mission in October 2011. The objective was to identify macro-critical structural reforms and to coordinate the two teams' work for the period October 2011 to December 2012.

2. The teams agreed that Mozambique's main macroeconomic challenges are to sustain higher and more inclusive economic growth going forward. To meet these challenges, Mozambique needs to enable broader-based economic activity led by the private sector, in particular in areas where it has competitive advantages, such as agriculture, traderelated services in support of booming commodity export sectors, labor-intensive manufacturing, and tourism. Given the low level of infrastructure, this will entail policies and reforms to boost public investment, coupled with enhancements in the business environment. While traditional aid will continue to address needs in infrastructure investment and the social sector, increasing public investment may require resorting to nonconcessional financing and stepping up capacity in the investment selection and debt management areas.

3. Based on this shared assessment, the teams identified seven structural reform areas as macro-critical, in view of their central role in achieving higher and more inclusive growth:

Debt management and investment planning. The authorities' ambitious investment program will need to be backed by a strong reform agenda to enhance capacity to manage fiscal risks and ensure value for money. In the field of investment selection, several measures will be implemented to establish an investment pipeline and define project selection standards and protocols. A new legal framework supporting private-public partnership and concessions will be implemented. Debt management will be strengthened to ensure that borrowing and investment decisions entail value for money. This will be underpinned by a new medium-term debt strategy.

Public financial management. The focus will be on enhancing the capacity to manage risks outside the central government, including in the area of state-owned enterprises (SOEs) and decentralized administrative units. To achieve this objective, the authorities will step up riskbased controls and audits, continue rolling out their new PFM system, and enhance budget execution and monitoring reports. Other critical measures aim at enhancing control of the wage bill, both in budget preparation and execution. These reforms are macro-critical since they will create fiscal space needed to reduce poverty and increase priority spending, while managing risks related to SOE's large-scale investment plans and enhancing the government's oversight.

Tax administration. Despite the strong increase in revenue collections, the tax system is still complex to administer and comply with. It is marked by numerous tax benefits and an overall low contribution from the mega-project sectors. Going forward, the government plans to facilitate tax compliance through electronic tax payment and continue to expand the tax base to 
cover the large informal sector. The revenue management system will be enhanced, in line with a set of agreed performance indicators. The large tax-payers unit will be made fully operational.

Social safety nets. The recent social unrest in light of the food and fuel price spikes has exposed the contrast of a fast-growing economy with still large pockets of poverty. This, in turn, undermines the country's long-term growth potential. To address this, the authorities intend to strengthen their safety nets. Measures include: (i) rationalizing and expanding health insurance coverage; (ii) strengthening higher education and vocational training; (iii) strengthening the financial sustainability and administration of the National Social Security Fund, and creating a new pension system for private sector workers; and (iv) improving the targeting of social protection systems to the most needy. These measures are macro-critical, as better health and education services, stronger pensions systems, and a more effective social safety net can enhance the productivity of the workforce and support social cohesion.

Natural resource wealth. Mozambique is endowed with rich natural resource reserves which are largely not exploited so far. With the recently started coal projects in Tete and a series of other projects in the coming years, the extractive sector is slated for a boom which could make significant contributions to the country's economic growth and government revenues. This poses challenges for the sector's legal frameworks and the government's capacity in managing contracts and revenues. In addition, Mozambique is in the process of attaining full membership of the Extractive Industries Transparency Initiative (EITI).

Investment climate. Mozambique's corporate sector is held back by the high costs of doing business. These arise mainly from weaknesses in governance, access to finance, power supply, tax and regulatory systems, and contract enforcement. Wide-ranging reforms are needed to address these issues. They are macro-critical because a better investment climate is conducive to supporting private sector activities, thereby broadening the country's productive and export base, creating jobs, and thus helping reduce poverty.

Financial sector stability and development. Credit to the private sector has strongly expanded during the last few years, and there are concerns about the impact on the quality of the loans. A number of measures are envisaged to strengthen the supervision of the financial sector, as well as the capacity to identity and address potential sources of vulnerabilities. Meanwhile, improving financial intermediation and access to credit remains a top priority. To this end, the authorities has prepared a preliminary draft of the 2011-20 Financial Sector Development Strategy which includes a wide-ranging and clearly sequenced action plan, covering ways to, among other things, enhance financial inclusion, competition, consumer protection, and financial literacy.

\section{The teams agreed on the following division of labor:}

Debt management and investment planning reforms. The Fund will continue to play a key role in building government capacity to assess debt sustainability and define a coherent debt strategy through TA and continued support from HQ. Both institutions will assist the authorities in 
strengthening their debt management capacity, with TA support from the Fund and on-site assistance from the Bank. The Fund will continue to play a key role in helping the authorities establish a project selection pipeline, in line with recent TA and program commitments, while the Bank will take a lead in enhancing project evaluation and monitoring processes and protocols from its office in Mozambique, in consultation with the Fund. The Fund review missions will provide further opportunities to assess progress in this field and discuss possible actions with the Bank.

Public financial management reform. The Bank and the Fund will cooperate in the field of rolling out the new PFM system to cover local administrations and SOEs engaging in large-scale infrastructure investments. The Fund will secure its support through regular TA missions from its RTAC office. The Bank will provide ongoing consultation from its local office and supervision missions of projects under implementation in this area. The Fund program review missions will provide further opportunities to assess progress in this field.

Tax administration reforms. The Fund will provide support through ongoing advice based on regular TA. The Bank will advance reforms in this area in the context of its business environment policies and portfolio.

Social safety net reform. The Bank will take a lead in this field through continued TA in the design of more comprehensive and performing safety nets, in cooperation with other development partners and international organizations (including UNESCO and ILO). The Fund will play its role in identifying the fiscal space for the safety nets. The results will be discussed among the collaborators on a regular basis, so as to inform policy discussions with the authorities. The Bank is also taking the lead in public pension reforms.

Natural resource wealth. The Fund will provide TA under the newly established Topical Trust Fund for Managing Natural Resource Wealth (TTF-MNRW), relating to the fiscal regime of the extractive sector, revenue forecasting, and natural resource statistics. The Bank is supporting Mozambique's implementation of EITI through its Multi-donor Trust Fund (MDTF). A Bank grant supports the update of the mining law and regulations and the model mining contract, and the development of a concessions database for gas and mining projects to support the government's forecasting and contract monitoring functions.

Investment climate reform. The Bank will take a lead in enhancing the investment climate, by deepening its agenda to help the authorities cut red tape and simplify the legal and regulatory framework. The results will be shared on an ongoing basis and discussed during the Fund program review missions.

Financial sector stability and development. The Fund will continue to help the Bank of Mozambique to build its capacity to assess risks to financial stability of the banking sector in upcoming missions, while the Bank will take the lead in supporting financial sector development 
and reforms, including through enhanced financial inclusion, competition, consumer protection, and financial literacy. The results of their respective work will be shared and discussed regularly.

5. The teams have the following requests for information from their counterparts:

- $\quad$ The Fund team requests to be kept informed of progress in the above macro-critical structural reform areas. Timing: when milestones are reached; and at least semiannually during Fund program review missions.

- $\quad$ The Bank team requests to be kept informed of the Fund's assessments of macroeconomic policies and prospects, and analytical work on areas under the Fund's lead, as well as on recommendations of Fund TA missions. Timing: in the context of Fund program review and other missions, and at least semi-annually.

6. The table below lists the teams' separate and joint work programs during October 2011- December 2012. 


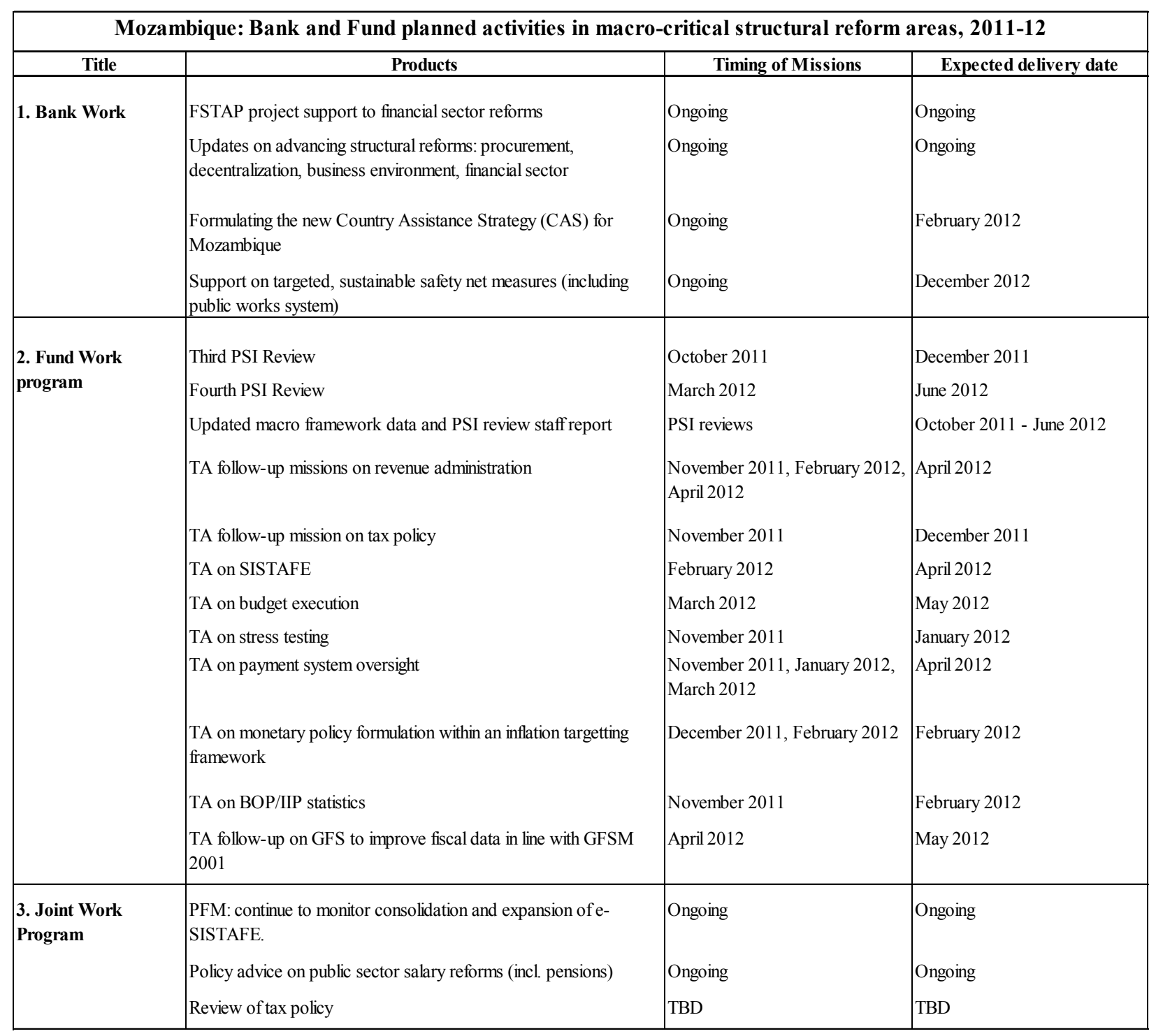




\section{APPENDiX III. MOZAMbiQue: StATISTICAL ISSUES}

\section{Assessment of Data Adequacy for Surveillance}

General: Data provision has some shortcomings, but is broadly adequate for surveillance. Despite the increase in budget resources allocated to the compilation of official statistics, continued high reliance on external funding raises concerns about the sustainability of the programs of the National Institute of Statistics (INE). The authorities are making efforts to improve the quality and timeliness of economic and financial data through participation in the Fund's General Data Dissemination System (GDDS) and in the external sector module of the GDDS Project for Anglophone African Countries (funded by the U.K. Department for International Development (DFID)). Weaknesses exist, particularly in the areas of national accounts, prices, and government finance statistics.

Real sector statistics: The national accounts are prepared by the INE in accordance with the 1993 System of National Accounts (1993 SNA). In August 2007, the INE released quarterly GDP estimates at constant prices covering 2000-07 for the first time, along with a revised annual GDP series for the period 1991-2006, with 2003 as the new base year. The authorities are working to strengthen quarterly national accounts compilation at current prices. The INE's new household income and expenditure survey and economic censuses leading to a new business registry still need to be incorporated to strengthen the national accounts. A revamped consumer price index for Maputo based on weights derived from the 2008-09 household survey was released in February 2011. A national index obtained by integrating the indices for Maputo, Beira, and Nampula was released in April 2006. INE has adopted a new software from INE Portugal which helps to correct a probable downward bias caused by carry-forward techniques for discontinued products. Several issues remain outstanding, however, including how to improve the housing market rent sample and expand coverage to include the Quelimane and Greater Maputo areas. There are insufficient sectoral labor market and employment data, and where available, they have limited coverage. A oneyear labor market survey of the entire country, undertaken by INE in collaboration with the Labor Ministry, was launched in October 2004.

Government finance statistics: Government finance statistics (GFS) are not compiled using an internationally accepted statistical methodology and no staff has been identified to do so. A complete list of public sector entities is lacking. Work on a correspondence table between budgetary information and GFS needs to be completed. In addition, work on an integrated information system to capture completely stocks and flow information needs further development. 
Monetary and financial statistics: A 2004 work plan was developed to implement the Monetary and Financial Statistics Manual (MFSM) and develop an integrated monetary database (IMD) to meet the needs of the Bank of Mozambique (BM), AFR, and STA. In November 2007 the IMD was completed and allows the derivation of accurate and timely monthly monetary statistics, while reducing BM's reporting burden.

Balance of payments: With assistance from STA, provided in the context of the GDDS regional project, the $\mathrm{BM}$ has made significant progress toward compiling and disseminating balance of payments (BOP) and international investment position (IIP) statistics that are fully aligned with the Balance of Payments Manual, fifth edition (BPM5). The BM has an adequate institutional framework for the compilation of BOP and IIP statistics. However, further strengthening of external sector statistics needs to focus on: strengthening information technology (especially to apply data warehouse and on-line analytical processing tools); excluding the effects of price and exchange rate fluctuations from reserve asset flows; applying a methodology (provided through STA technical assistance) to estimate reinvested profits and stocks of financial assets and liabilities held abroad by the nonfinancial public sector; improving business surveys; publishing methodological notes, in general, and more data covering the Reserves Template, foreign direct investment, goods trade and current transfers; and beginning the gradual process to implement the new Balance of Payments and International Investment Position Manual, sixth edition. Joint work with other institutions to improve the quality of external trade data, especially with regard to price and volume indices, also merits attention.

\section{Data Standards and Quality}

Mozambique commenced its participation in the General Data Dissemination System (GDDS) in November 2003; but has since then not updated much of its metadata.

In May 2005, an update of the June 2002 data module of the Report on the Observance of Standards and Codes (Data ROSC) was prepared. Improvements in the institutional environment and increased allocation of resources for the compilation of national accounts and balance of payments statistics aimed to address weaknesses in the prerequisites for the quality of the statistics. Methodological soundness, accuracy, and reliability of macroeconomic statistics began to show improvements as a result of these efforts. 


\section{Reporting to STA}

Mozambique does not report fiscal data for publication in the IFS or the Government Finance Statistic Yearbook (GFSY). Mozambique now reports monthly monetary data to STA using the standardized reporting forms (SRFs). As a result, these enhanced data are being published in the International Financial Statistics (IFS) Supplement. In 2007, the BM started to compile and report comprehensive IIP data in the Balance of Payments Statistics Yearbook. 
Mozambique: Table of Common Indicators Required for Surveillance

(As of October 31, 2011)

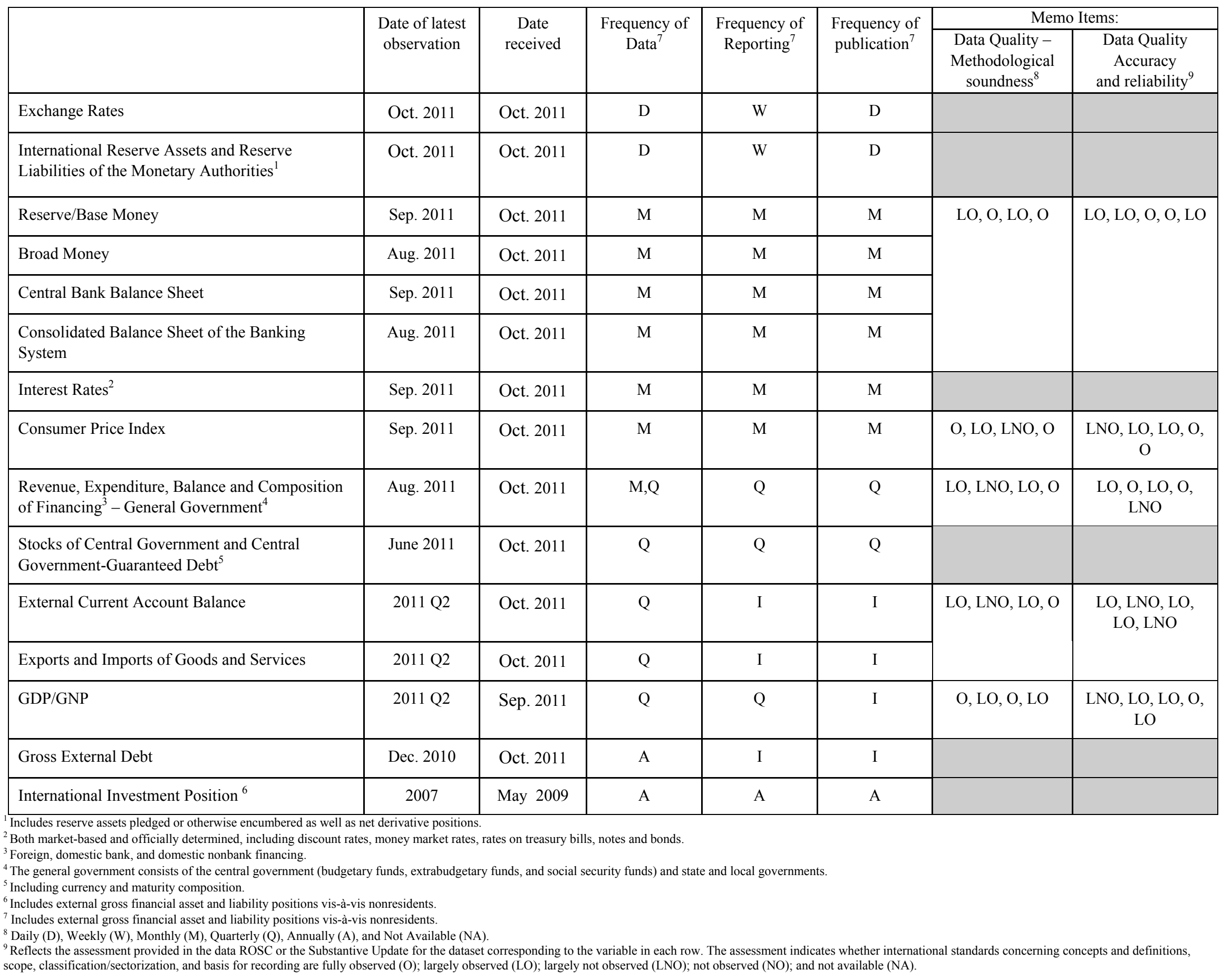




\section{IMF Completes Third Review Under the Policy Support Instrument for Mozambique}

The Executive Board of the International Monetary Fund (IMF) has completed the third review under the three-year Policy Support Instrument (PSI) for the Republic of Mozambique. ${ }^{1}$ The Board's decision was taken on a lapse of time basis. ${ }^{2}$

Mozambique continues to weather the global economic turmoil well. Real GDP growth is projected to remain above 7 percent in 2011, benefiting from good harvests, a robust performance in the services sector, and the coming online of new megaprojects in the natural resource sector. While risks related to the external environment have increased, Mozambique's macroeconomic stability and prudent policy mix over the past few years should help the economy mitigate the impact of a temporary global downturn. The tightening of monetary policy in 2011 has been effective in curtailing inflation. The prudent execution of the 2011 budget has contributed to a judicious policy mix that has fostered macroeconomic stability at a critical time and positioned the country well to respond to downside risks should such a need arise. All quantitative targets for end-June 2011 were met, except for reserve money growth which was missed by a small margin. Progress on the structural front has also been good.

The authorities' economic program under the PSI will continue to emphasize preserving macroeconomic stability and debt sustainability while promoting economic and social development. Monetary policy will be geared toward further reducing inflation while fostering financial deepening. Fiscal policy will seek to step up public investment to close the infrastructure gap and support an expansion of social safety nets to address chronic poverty, consistent with the authorities' four-year poverty reduction strategy (2011-2014). The necessary fiscal space is expected to be created through a continued strong revenue effort, the phasing-out of the fuel subsidy, selective non concessional borrowing, and a moderate increase in domestic borrowing. The program's structural reforms will focus on improving public financial management including debt management, tax administration and policy, and monetary policy framework. 
The Executive Board approved Mozambique's second three-year PSI on June 14, 2010 (see Press Release No. 10/242), upon expiration of the previous PSI and completion of the final review under a 12-month high-access arrangement (SDR 113.6 million) under the Exogenous Shocks Facility, aimed at providing temporary balance of payments support in dealing with the global crisis (see Press Release No. 09/247).

\footnotetext{
1 The IMF's framework for PSIs is designed for low-income countries that may not need IMF financial assistance, but still seek close cooperation with the IMF in preparation and endorsement of their policy frameworks. PSI-supported programs are based on country-owned poverty reduction strategies adopted in a participatory process involving civil society and development partners. A country's performance under a PSI is reviewed bi-annually.

$\stackrel{2}{=}$ The Executive Board takes decisions under its lapse of time procedure when it is agreed by the Board that a proposal can be considered without convening formal discussions.
} 